\title{
The Domestic and International Effects of Interstate U.S. Banking*
}

\author{
Fabio Ghironi ${ }^{\dagger}$ \\ Boston College, \\ Federal Reserve Bank of Boston, \\ $N B E R$, and $E A B C N$
}

\author{
Viktors Stebunovs ${ }^{\ddagger}$ \\ Board of Governors \\ of the Federal Reserve System
}

December 17, 2010

Comments Welcome

\begin{abstract}
This paper studies the domestic and international effects of the transition to an interstate banking system implemented by the U.S. since the late 1970s in a dynamic, stochastic, general equilibrium model with endogenous producer entry. Interstate banking reduces the degree of local monopoly power of financial intermediaries. We show that the an economy that implements this form of deregulation experiences increased producer entry, real exchange rate appreciation, and a current account deficit. The rest of the world experiences a long-run increase in GDP and consumption. Less monopoly power in financial intermediation results in less volatile business creation, reduced markup countercyclicality, and weaker substitution effects in labor supply in response to productivity shocks. Bank market integration thus contributes to a moderation of firm-level and aggregate output volatility. In turn, trade and financial ties between the two countries in our model allow also the foreign economy to enjoy lower GDP volatility in most scenarios we consider. The results of the model are consistent with features of the U.S. and international business cycle after the U.S. began its transition to interstate banking.
\end{abstract}

JEL Codes: E32; F32; F41; G21.

Keywords: Business cycle volatility; Current account; Deregulation; Interstate banking; Producer entry; Real exchange rate.

\footnotetext{
${ }^{*}$ This paper was circulated previously under the title "The Domestic and International Effects of Financial Deregulation." First draft: July 21, 2007. For helpful comments, we thank Alessandro Barattieri, Rucha Bhate, Claudia Buch, Silvio Contessi, Mathias Hoffmann, Guay Lim, Alan Sutherland, Cédric Tille, and conference and seminar participants at Atlanta Fed, Boston Fed (seminar and Dynare Conference 2008), Bundesbank Spring Conference 2010 (International Risk Sharing and Global Imbalances), ECB Financial Markets and Macroeconomic Stability Conference, Econometric Society NASM 2008, EEA 2008, ESEM 2009, Federal Reserve Board, HEC Montréal, IMF, Kansas City Fed (System Conference on Macroeconomics 2008), LACEA 2008, MIT, NBER IFM Spring 2008, Reserve Bank of Australia 2007 Research Workshop on Monetary Policy in Open Economies, SED 2008, University of Connecticut, University of Houston, University of Maryland, University of Wisconsin-Madison, and Vanderbilt University. We are grateful to Alessandro Barattieri and Rucha Bhate for outstanding research assistance. All remaining errors are ours. Ghironi thanks the NSF for financial support through a grant to the NBER. The views presented in this paper are solely of the authors and do not necessarily represent the views or policy of the Federal Reserve Bank of Boston, the Federal Reserve Board, or the NBER.

${ }^{\dagger}$ Department of Economics, Boston College, 140 Commonwealth Avenue, Chestnut Hill, MA 02467-3859, U.S.A. or Fabio.Ghironi@bc.edu. URL: http://www2.bc.edu/ ghironi.

${ }^{\ddagger}$ Board of Governors of the Federal Reserve System, Division of Monetary Affairs, 20th Street and Constitution Avenue, NW, Washington, DC 20551, U.S.A. or Viktors.Stebunovs@frb.gov.
} 


\section{Introduction}

The U.S. banking system was highly segmented within and across states until the late 1970s. For decades, a myriad of state and federal laws limited where banks could operate. States effectively barred banks from other states, so the country had fifty banking systems instead of one national banking system (Morgan, Rime, and Strahan, 2004). Moreover, most states also prohibited crosscounty branching within the state, so the country effectively had as many banking systems as counties. Starting in the late 1970s, successive waves of state-level deregulation lifted restrictions on bank expansion both within and across states. By the early 1990s, almost all states had removed such restrictions. The transition to interstate banking was completed with passage of federal legislation in the mid 1990s. ${ }^{1}$

What were the macroeconomic consequences of the transition to interstate banking for the U.S. and the international economy? This paper addresses this question in a dynamic, stochastic, general equilibrium (DSGE) model with endogenous producer entry and a role for financial intermediation. We argue that the removal of banking segmentation in the U.S. between the late 1970s and the early 1990s may have contributed to observed developments of the U.S. and international business cycle since the beginning of the 1980s.

A growing literature emphasizes the role of producer entry as a mechanism for propagation of domestic and international fluctuations. ${ }^{2}$ With the exception of Stebunovs (2008), the models in this literature assume that entrants finance their entry costs by raising capital in a perfectly competitive stock market. However, bank finance is a more realistic assumption for small firms, which represent a large portion of the U.S. economy. ${ }^{3}$ The structure of the banking system is thus likely to affect entry decisions and the propagation of fluctuations, and changes in the banking system itself can trigger macroeconomic dynamics through their impact on business creation.

In fact, there is substantial empirical evidence of the connection between producer entry and the structure of banking. This evidence emphasizes that potential entrants in product markets face greater difficulty gaining access to credit in localities where banking is concentrated and subject to tighter restrictions on geographical expansion than in localities where banking is more competitive (Black and Strahan, 2002, Cetorelli and Strahan, 2006, and Kerr and Nanda, 2007). These and

\footnotetext{
${ }^{1}$ We provide a more detailed account of the removal of geographical restrictions to U.S. bank expansion in the Appendix.

${ }^{2}$ See Bilbiie, Ghironi, and Melitz (2007) and references therein.

${ }^{3}$ According to the U.S. Small Business Administration, small firms (with fewer than 500 employees) represent 99.7 percent of all firms, employ half of all private sector employees, and produce half of non-farm private GDP.
} 
other studies emphasize that the transition to interstate banking in the U.S. - a form of financial market deregulation - reduced the local monopoly power of commercial banks, facilitating access to finance for new entrants in product markets and resulting in an increased number of operating non-financial establishments. ${ }^{4}$

We study the domestic and international effects of such easier access to finance in a twocountry model that incorporates endogenous producer entry subject to sunk costs, deviations from purchasing power parity (PPP), and monopoly power in financial intermediation. Our model builds on Ghironi and Melitz (2005) and Bilbiie, Ghironi, and Melitz (2007) by assuming that investment in the economy takes the form of the creation of new production lines (for convenience, identified with firms). Sunk costs and a time-to-build lag induce the number of firms to respond slowly to shocks, consistent with the notion that the number of productive units is fixed in the short run. Following Stebunovs (2008), we assume that new entrants must obtain funds from financial intermediaries (henceforth, banks) to cover entry costs. Bank markets are initially segmented across different locations within each country in our model, and local market power induces banks to erect a financial barrier to firm entry to protect the profitability of lending. This reduces average entry relative to the competitive benchmark, explaining the evidence in Black and Strahan (2002), Cetorelli and Strahan (2006), and Kerr and Nanda (2007). ${ }^{5}$ We take bank concentration as exogenous, and we study the consequences of the removal of within-country banking segmentation, resulting in a decrease in the local monopoly power of banks, in one of the countries in our model.

We show that the economy that implements this deregulation experiences increased producer entry, real exchange rate appreciation, and a current account deficit. Reduced local monopoly power of banks makes the economy that deregulates a relatively more attractive environment for potential entrants, and the number of firms that operate in the economy increases, consistent with the findings of the empirical finance literature. Average firm size decreases, as documented by Cetorelli and Strahan (2006) and Kerr and Nanda (2007). As in Ghironi and Melitz (2005), entry in the economy that deregulates pushes relative labor costs upward, inducing real appreciation. ${ }^{6}$ Moreover, when we allow for international borrowing and lending, domestic bank market integration induces the economy that deregulates to run a current account deficit to finance increased firm entry. The rest

\footnotetext{
${ }^{4}$ Jayaratne and Strahan (1998) and Dick (2006) find that loan prices and net interest rate margins declined with the integration of U.S. bank markets. Berger, Demsetz, and Strahan (1999) document that the deregulation caused reduced concentration in local banking. See Stebunovs (2008) for a more detailed discussion.

${ }^{5}$ See also Bertrand, Schoar, and Thesmar (2007). Our model incorporates Cestone and White's (2003) insight that entry deterrence takes place through financial rather than product markets.

${ }^{6}$ Non-traded goods and trade costs cause PPP deviations in the model. Replacing non-traded goods with the assumption of home bias in preferences generates similar results.
} 
of the world experiences higher GDP and consumption in the long run.

Comparing business cycle fluctuations around the pre- and post-deregulation steady states, we also show that less monopoly power in financial intermediation results in less volatile business creation, reduced markup countercyclicality, and weaker substitution effects in labor supply in response to productivity shocks - the source of business cycles in our model. Removal of banking segmentation thus contributes to moderation of firm-level and aggregate output volatility. ${ }^{7}$ In turn, trade and financial ties between the two countries allow also the foreign economy to enjoy lower GDP volatility in most scenarios we consider. ${ }^{8}$

Interpreting the economy that removes banking segmentation in our exercise as the U.S., the predictions of our model are consistent with features of the U.S. and international business cycle following the waves of U.S. banking integration started at the end of the 1970s: The U.S. experienced real appreciation and significant external borrowing in the first half of the 1980s and after the mid1990s - periods that followed the first wave of deregulation and the completion of the transition to interstate banking, respectively. The decades after the early 1980s - and before the crisis that begun in 2007-were also marked by a reduction of macroeconomic volatility around the world. ${ }^{9}$ Our paper thus offers an explanation of developments in the U.S. and international business cycle that complements those already present in the literature. ${ }^{10}$

The conventional explanation for the contemporaneous occurrence of U.S. exchange rate appreciation and external borrowing in the 1980s relies on the traditional Mundell-Fleming analysis of the consequences of expansion in government spending and the monetary policy contraction implemented by Paul Volcker's Federal Reserve. But the tight association between federal budget and external balance has been challenged by recent literature. For instance, Erceg, Guerrieri, and Gust (2005) find that a fiscal deficit has a relatively small effect on the U.S. trade balance, irrespective

\footnotetext{
${ }^{7}$ The reduction in firm-level volatility is consistent with evidence in Correa and Suarez (2007), who find a causal link between banking deregulation and lower firm-level volatility in the U.S.

${ }^{8}$ Our model also implies that the removal of banking segmentation in one of the two countries improves long-run welfare in both countries as households enjoy higher utility from consumption that more than offsets the disutility of higher labor effort.

${ }^{9}$ Stock and Watson (2003) document that the decline in U.S. business cycle volatility begun in 1984 . Our model predicts that it takes approximately six years for the number of producers to reach the new steady state following banking deregulation. Thus, the prediction of the model is consistent with a reduction in business cycle volatility observed approximately six years after the first wave of deregulation in the late 1970s.

${ }^{10}$ Since our model predicts permanent real appreciation following permanent banking deregulation, the model does not explain the return of the U.S. effective real exchange rate to pre-appreciation levels after the appreciation phases in the 1980s and 1990s. This can be attributed to the reversal of other forces that contributed to the appreciations as well as, for instance, coordinated exchange rate intervention in the second half of the 1980s. If one views banking integration as a characteristic of more developed countries, the prediction of persistently higher average prices is consistent with the evidence that prices are indeed higher in higher-income countries.
} 
of whether the source is a spending increase or a tax cut. With respect to U.S. trade balance and real exchange rate dynamics in the second half of the 1990s, Hunt and Rebucci (2005) conclude that accelerating productivity growth in the U.S. contributed only partly to appreciation and trade balance deterioration. They find that a portfolio preference shift in favor of U.S. assets and uncertainty and learning about the persistence of both productivity and preference shocks are needed for their model to explain the data. Rather than emphasizing the demand-side effect of preference shifts, Caballero, Farhi, and Gourinchas (2008) provide a model that rationalizes external imbalances as the outcome of growth differentials across different regions of the world and heterogeneity in these regions' capacity to generate financial assets. Mendoza, Quadrini, and Ríos-Rull (2009) argue that imbalances can be the outcome of international financial integration when countries differ in financial market development (interpreted as the enforcement of financial contracts) and show that countries with more advanced financial markets accumulate foreign liabilities in a gradual, long-lasting process. Finally, Fogli and Perri (2006) argue that imbalances are a consequence of business cycle moderation in the U.S. In their model, if a country experiences a fall in volatility greater than that of its partners, its relative incentives to accumulate precautionary savings weaken, and this results in an equilibrium deterioration of its external balance. ${ }^{11}$ The moderation of business cycle volatility between the 1980s and the crisis that begun in 2007-often referred to as the Great Moderation - has been the subject of extensive literature that attributes it partly to favorable changes in the shocks to the economy and partly to improved policy. ${ }^{12}$

Our model provides a complementary explanation of observed phenomena, based on the effects of removal of banking segmentation that made the U.S. banking system more competitive (at the level of local borrowers) than that of the rest of the world. ${ }^{13}$ We emphasize that our results hinge on lower bank monopoly power at the local level. Even if bank consolidation was a well documented phenomenon in the U.S. since the 1980s, it is well established by the empirical finance literature referenced above that interstate banking reduced the degree of bank monopoly power at the level of local borrowers - put differently, while the total number of U.S. banks may have declined as a

\footnotetext{
${ }^{11}$ Other explanations of the recent dynamics of the U.S. external position emphasize demographics (Ferrero, 2007), a "global saving glut" (Bernanke, 2005), and valuation effects (Gourinchas and Rey, 2007).

${ }^{12}$ See Stock and Watson (2003) and references therein. An incomplete list of more recent, relevant references includes Cogley and Sargent (2005), Giannone, Lenza, and Reichlin (2008), Justiniano and Primiceri (2008), and Sims and Zha (2006).

${ }^{13}$ Our analysis can of course be applied also to the intra-European and international consequences of bank market integration within the European Union (EU) since the signing of the Single European Act in 1986. However, the process of EU banking integration has been lagging behind the implementation of interstate banking in the U.S. See the Appendix for historical details. De Bandt and Davis (2000) provide evidence that the behavior of large banks in Europe was not as competitive as that of U.S. counterparts over the period 1992-1996. Regarding small banks, the level of competition in Europe was even lower.
} 
result of consolidation, the number of those represented at any given location tended to increase, generating the effects that we capture. In our model, a differential in the competitiveness of the banking system induces real appreciation of the dollar and U.S. external borrowing by making the U.S. a more attractive environment for business creation. As in Caballero, Farhi, and Gourinchas (2008), Mendoza, Quadrini, and Ríos-Rull (2009), and Fogli and Perri (2006), current account deficit and the accumulation of a persistent (although not permanent) net foreign debt position arise as an equilibrium phenomenon. However, while Caballero, Fahri, and Gourinchas do not link business cycle moderation with global imbalances, and Fogli and Perri take moderation as exogenous, we provide a unified explanation of external borrowing during the post-deregulation transition and eventual business cycle moderation for given stochastic productivity process without requiring long-run productivity differentials. ${ }^{14}$ An element of similarity between our approach and those of Caballero, Fahri, and Gourinchas and Mendoza, Quadrini, and Ríos-Rull is that net foreign asset imbalances arise as a consequence of capital mobility across asymmetric financial systems: In Caballero, Fahri, and Gourinchas, there is asymmetric ability to generate financial assets; in Mendoza, Quadrini, and Ríos-Rull, there is asymmetric enforcement of financial contracts; in our model, the removal of within-country bank market segmentation results in an asymmetric degree of banking competition across countries. ${ }^{15}$

The remainder of the paper is organized as follows. Section 2 presents the benchmark model with non-traded goods under a balanced trade assumption. Section 3 discusses real exchange rate determination in our model and the mechanism for appreciation following banking deregulation. Section 4 presents impulse responses to a permanent, unilateral banking deregulation that substantiate the results and intuitions in Section 3. Section 5 extends the model to allow for international capital flows to show the emergence of external borrowing in response to deregulation. Section 6 incorporates countercyclical firm markups and elastic labor supply to highlight the mechanism for

\footnotetext{
${ }^{14}$ Of course, our model does not explain (and does not aim to explain) the period of financial market turmoil that begun in 2007 and its business cycle implications. For this purpose, the model should include-at a minimumheterogeneity in borrower quality, asymmetric information, and equilibrium default in response to the state of the economy. One could then re-cast the analysis of entry subject to sunk costs as one of the decision by heterogeneous households to enter home ownership, facilitated by various forms of market deregulation that made access to finance easier. But this analysis is beyond the scope of this paper.

${ }^{15}$ By focusing on the role of financial intermediaries, our paper also contributes to a recent, fast growing literature on the consequences of endogenous producer entry in macroeconomic models. In addition to the works mentioned above, see Bergin and Corsetti (2008), Bilbiie, Ghironi, and Melitz (2008), Corsetti, Martin, and Pesenti (2007, 2008), Elkhoury and Mancini Griffoli (2006), Ghironi and Melitz (2007), Méjean (2008), and Lewis (2006). Our setup preserves the key international relative price and external balance implications of entry in the Ghironi-Melitz model while removing firm heterogeneity and fixed export costs as a source of endogenous non-tradedness and introducing an exogenous non-traded sector (as in Méjean, 2008) or home bias in preferences.
} 
the moderation of business cycle volatility. Section 7 concludes. The Appendix contains a summary of the U.S. transition to interstate banking between the late 1970s and the mid 1990s, technical details, and the model with home bias.

\section{The Benchmark Model}

We begin by developing a version of our model under financial autarky.

The world consists of two countries, home and foreign. We denote foreign variables with an asterisk. Each country is populated by a unit mass of atomistic, identical households, a discrete number of banks, and a continuum of firms. In each country, there are several exogenously given locations with a discrete number of banks and a local continuum of firms in each of them. Monopolistically competitive firms in the traded sector must borrow from banks to finance sunk entry costs, and they have no collateral to pledge except a stream of future profits. ${ }^{16}$ Each firm then produces a firm-specific consumption good for sale in the domestic and export markets. Firm entry reduces the stream of future profits of both incumbents and entrants - and thus the amount pledgeable for entry loan repayments - by reducing the share of aggregate demand allocated to each firm.

Before deregulation, firms are restricted to borrow from local banks. These use their monopoly power on the loans they issue to extract all the future profits from the prospective entrants they finance. Each bank holds a portfolio of outstanding loans and decides on the number of new loans to be issued (that is, on the number of entrants to be financed) in each period. ${ }^{17}$ Each bank trades the increase in revenue from expanding its firm portfolio (portfolio expansion effect) against the decrease in revenue from all firms in its portfolio due to reduced market share per firm (profit destruction effect). The profit destruction effect induces credit rationing at the extensive margin: Less prospective entrants receive funding than with perfectly competitive financial markets. Each bank supplies one-period deposits to domestic households in a perfectly competitive deposit market. The bank then uses the deposits to fund firm entry. Thus, the cost that each bank faces is the deposit interest rate. Bank deregulation lifts the restriction on borrowing from banks at a different location within the country. The number of banks to which a borrower has access increases, hence reducing bank monopoly power. ${ }^{18}$

\footnotetext{
${ }^{16}$ Financial frictions that we leave unspecified force prospective entrants to borrow the amount necessary to cover sunk entry costs from banks rather than to raise funds directly in equity markets.

${ }^{17}$ Banks compete in the number of entrants in Cournot fashion as in the static, partial equilibrium model of González-Maestre and Granero (2003). Since banks extract all firm profits through loan repayments, banks de facto hold portfolios of firms in the economy. Financial intermediaries are equity holders also in Gertler and Karadi (2009).

${ }^{18}$ Since the completion of financial deregulation in the U.S. in 1994, it is increasingly less plausible to view bank-
} 
For expositional simplicity, we present the model economy below normalizing the number of banking locations in each country to one. We denote the number of banks represented at this location with $H \geq 1$ ( $H^{*}$ in the foreign country). If the number of locations were $M>1$, following integration of the home banking market, the product $H M$ would replace $H$ in the equations where this appears: Before deregulation, prospective entrants can borrow only from the $H$ banks represented at their location; after deregulation, they can borrow from $H M$ banks. Having normalized the number of locations to one, this is isomorphic to an increase in the number $H$ of banks represented at this location. ${ }^{19,20}$

All contracts and prices in the world economy are written in nominal terms. Prices are flexible. Thus, we only solve for the real variables in the model. However, as the composition of consumption baskets in the two countries changes over time (affecting the definitions of the consumption-based price indexes), we introduce money as a convenient unit of account for contracts. Money plays no other role in the economy. For this reason, we do not model the demand for cash currency, and we resort to a cashless economy as in Woodford (2003).

\section{Households}

We focus on the home economy. The representative home household supplies $L$ units of labor inelastically in each period at the nominal wage rate $W_{t}$, denominated in units of home currency. The household maximizes expected intertemporal utility from consumption $\left(C_{t}\right), E_{t} \sum_{s=t}^{\infty} \beta^{s-t} \frac{\left(C_{s}\right)^{1-\gamma}}{1-\gamma}$, where $\beta \in(0,1)$ is the subjective discount factor and $\gamma>0$ is the inverse of the intertemporal elasticity of substitution, subject to the budget constraint specified below. At time $t$, the household consumes the basket of goods $C_{t}=\left(C_{T, t} / \alpha\right)^{\alpha}\left[C_{N, t} /(1-\alpha)\right]^{1-\alpha}$, where $C_{T, t}$ is a basket of home and foreign tradable goods, $C_{N, t}$ is a non-tradable good, and $\alpha \in(0,1)$ is the weight of the tradable basket in consumption. ${ }^{21}$ The consumption-based price index is then $P_{t}=\left(P_{T, t}\right)^{\alpha}\left(P_{N, t}\right)^{1-\alpha}$, where

ing markets as local (Cetorelli and Strahan, 2006). The ability of banks to expand across local markets and new technologies that allow banks to lend to distant borrowers act to limit the incumbent banks' local monopoly power (Petersen and Rajan, 2002).

${ }^{19}$ We remark that while the normalization $M=1$ implies that $H$ becomes the total number of home banks in the model presentation below, our results do not hinge on deregulation resulting in an increase in the total number of home banks in reality (or in the model without normalization). In fact, consolidation post-deregulation lowered the total number of banks in the U.S. But this is not inconsistent with an increase in the number of banks represented in each location, and a decline in their local monopoly power (consistent with the evidence), which is what our model is intended to capture.

${ }^{20}$ We abstract from endogenous entry into banking as function of economic conditions (for given regulatory environment). While there is evidence of cyclical variation of entry in goods markets (see Bilbiie, Ghironi, and Melitz, 2007, and references therein), the evidence of bank creation at business cycle frequency is less pervasive.

${ }^{21}$ Differently from Ghironi and Melitz (2005), we do not model the endogenous determination of the subset of traded goods within a tradable set, since this is not central to the analysis in this paper. All tradable goods that 
$P_{T, t}$ is the price index of the tradable basket, and $P_{N, t}$ is the price of the non-tradable good. The basket of tradable goods is $C_{T, t}=\left(\int_{\omega \in \Omega} c_{t}(\omega)^{(\theta-1) / \theta} d \omega\right)^{\theta /(\theta-1)}$, where $\theta>1$ is the symmetric elasticity of substitution. At any given time $t$, only a subset of goods $\Omega_{t} \subset \Omega$ is actually available for consumption at home and abroad. Let $p_{t}(\omega)$ denote the home currency price of traded good $\omega \subset \Omega_{t}$. Then, $P_{T, t}=\left(\int_{\omega \in \Omega_{t}} p_{t}(\omega)^{1-\theta} d \omega\right)^{1 /(1-\theta)}$. The household's demand for each individual traded good $\omega$ is $c_{t}(\omega)=\alpha\left(p_{t}(\omega) / P_{T, t}\right)^{-\theta}\left(P_{t} / P_{T, t}\right) C_{t}$. The household's demand for the non-tradable good is $C_{N, t}=(1-\alpha)\left(P_{t} / P_{N, t}\right) C_{t}$.

The foreign household supplies $L^{*}$ units of labor inelastically in each period in the foreign labor market at the nominal wage rate $W_{t}^{*}$, denominated in units of foreign currency. It maximizes a similar utility function, with identical parameters and similarly defined consumption basket. The subset of tradable goods available for consumption in the foreign economy during period $t$ is $\Omega_{t}^{*} \subset \Omega$ and it coincides with the subset of tradable goods that are available in the home economy $\left(\Omega_{t}^{*}=\Omega_{t}\right)$.

Households in each country hold two types of assets: one-period deposits supplied by domestic banks and shares in a mutual fund of domestic banks. ${ }^{22,23}$ We assume that deposits pay risk-free, consumption-based real returns. ${ }^{24}$ Let $x_{t}$ be the share in the mutual fund of $H$ home banks held by the representative home household entering period $t$. The mutual fund pays a total profit in each period (in units of currency) equal to the total profit of all home banks, $P_{t} \sum_{h \in H} \pi_{t}(h)$, where $\pi_{t}(h)$ denotes the profit of home bank $h$. During period $t$, the household buys $x_{t+1}$ shares in the mutual fund. The date $t$ price (in units of currency) of a claim to the future profit stream of the mutual fund is equal to the nominal price of claims to future profits of home banks, $P_{t} \sum_{h \in H} v_{t}(h)$, where $v_{t}(h)$ is the price of claims to future profits of bank $h$. In addition to mutual fund share holdings $x_{t}$, the household enters period $t$ with deposits $B_{t}$ in units of consumption. It receives gross interest income on deposits, dividend income on mutual fund share holdings, the value of selling its initial share position, and labor income. The household allocates these resources between consumption and purchases of deposits and shares to be carried into next period. The period budget constraint

are produced in equilibrium are also traded, and there is an exogenously non-tradable good in each country. We present in the Appendix an alternative version of the model in which there is no non-tradable good, and home bias in consumption preferences for tradable goods is the source of PPP deviations.

${ }^{22}$ Because of the assumption that banks de facto own domestic firms, this implies that households are the ultimate owners of the firms. However, as we show below, bank monopoly power in lending distorts the allocation of funds from the competitive deposit market to the ultimate destination (new firms).

${ }^{23}$ The assumption that banks lend locally but collect deposits in a country-wide deposit market substitutes a scenario in which deposits are collected locally but there is a country-wide interbank lending market. The latter scenario would require to study the determination of the interbank lending rate in an environment with non-atomistic banks.

${ }^{24}$ We assume that nominal returns are indexed to consumer price inflation, so that deposits provide a risk-free, real return in units of the consumption basket. 
(in units of consumption) is

$$
B_{t+1}+x_{t+1} \sum_{h \in H} v_{t}(h)+C_{t}=\left(1+r_{t}\right) B_{t}+x_{t} \sum_{h \in H}\left(\pi_{t}(h)+v_{t}(h)\right)+w_{t} L,
$$

where $r_{t}$ is the consumption-based interest rate on holdings of deposits between $t-1$ and $t$ (known with certainty at $t-1$ ), and $w_{t}=W_{t} / P_{t}$ is the real wage. The home household maximizes its expected intertemporal utility subject to (1).

The Euler equations for deposits and share holdings are: $1=\beta\left(1+r_{t+1}\right) E_{t}\left[\left(C_{t+1} / C_{t}\right)^{-\gamma}\right]$, and $v_{t}=\beta E_{t}\left[\left(C_{t+1} / C_{t}\right)^{-\gamma}\left(\pi_{t+1}+v_{t+1}\right)\right]$, where $v_{t}=\sum_{h \in H} v_{t}(h)$ and $\pi_{t+1}=\sum_{h \in H} \pi_{t+1}(h)$. Forward iteration of the Euler equation for share holdings and absence of speculative bubbles yield the value of the mutual fund, $v_{t}$, as expected present discounted value of the stream of bank profits, $\left\{\pi_{s}\right\}_{s=t+1}^{\infty} \cdot{ }^{25}$

\section{Firms}

\section{Traded Goods Producers}

There is a continuum of firms in each country, each producing a different traded variety $\omega \in \Omega$. Aggregate labor productivity is indexed by $Z_{t}\left(Z_{t}^{*}\right)$, which represents the effectiveness of one unit of home (foreign) labor. Production requires only one factor, labor: The output of firm $\omega$ is $y_{t}(\omega)=Z_{t} l_{t}(\omega)$, where $l_{t}(\omega)$ is the amount of labor employed by the firm. The unit production cost, measured in units of the consumption basket $C_{t}$, is $w_{t} / Z_{t}$. Similarly, the unit cost for foreign firms (measured in units of the foreign consumption basket) is $w_{t}^{*} / Z_{t}^{*}$, where $w_{t}^{*}=W_{t}^{*} / P_{t}^{*}$ is the foreign real wage. Home and foreign traded goods producers serve both their domestic and export markets. Exporting is costly, and it involves a melting-iceberg trade cost $\tau>1\left(\tau^{*}>1\right)$.

All traded goods producers face a residual demand curve with constant elasticity $\theta$ in both markets, and they set flexible prices that reflect the same proportional markup $\mu \equiv \theta /(\theta-1)$ over marginal cost. Let $p_{D, t}(\omega)$ and $p_{X, t}(\omega)$ denote the nominal domestic and export prices of a home firm (in the currency of the destination market). Define the relative prices $\rho_{D, t}(\omega) \equiv p_{D, t}(\omega) / P_{T, t}$, $\rho_{T, t} \equiv P_{T, t} / P_{t}, \rho_{X, t}(\omega) \equiv p_{X, t}(\omega) / P_{T, t}^{*}$, and $\rho_{T, t}^{*} \equiv P_{T, t}^{*} / P_{t}^{*}$. Then, $\rho_{D, t}(\omega)=\left(\rho_{T, t}\right)^{-1} \mu w_{t} / Z_{t}$ and $\rho_{X, t}(\omega)=\left(\rho_{T, t}^{*}\right)^{-1} \tau Q_{t}^{-1} \mu w_{t} / Z_{t}$, where $Q_{t}=\varepsilon_{t} P_{t}^{*} / P_{t}$ is the consumption-based real exchange rate (units of home consumption per unit of foreign consumption), and $\varepsilon_{t}$ is the nominal exchange

\footnotetext{
${ }^{25}$ We omit the transversality conditions for deposits and shares. Similar Euler equations, transversality conditions, and expression for $v_{t}^{*}$ hold abroad.
} 
rate (units of home currency per unit of foreign). Total profits of firm $\omega$ in period $t$ are given by $d_{t}(\omega)=d_{D, t}(\omega)+d_{X, t}(\omega)$, where $d_{D, t}(\omega)=\alpha\left(\rho_{D, t}(\omega)\right)^{1-\theta} C_{t} / \theta$ denotes profits from domestic sales and $d_{X, t}(\omega)=\alpha Q_{t}\left(\rho_{X, t}(\omega)\right)^{1-\theta} C_{t}^{*} / \theta$ denotes profits from exports. Since all firms behave identically in equilibrium, we drop the index $\omega$ below. ${ }^{26,27}$

\section{Non-Traded Good Producers}

There is a constant mass of firms in each country producing the homogeneous non-traded good. These firms are perfectly competitive and possess the same technology as the firms producing traded goods. ${ }^{28}$ Labor is perfectly mobile across sectors in each country. Hence, the price of the non-traded good, in real terms relative to the domestic price index, is given by $\rho_{N, t}=P_{N, t} / P_{t}=w_{t} / Z_{t}$. Foreign non-traded good producers behave in a similar way.

\section{Banks and Firm Entry}

In every period there is an unbounded number of prospective entrants in both countries' traded sectors. Prior to entry, firms face a sunk entry cost of one effective labor unit, equal to $w_{t} / Z_{t}$ $\left(w_{t}^{*} / Z_{t}^{*}\right)$ units of the home (foreign) consumption basket. Since there are no fixed production costs, all firms produce in every period, until they are hit with an exogenous exit shock, which occurs with probability $\delta \in(0,1)$ in every period. Entrants are forward looking, and correctly anticipate their future expected profits $d_{t}\left(d_{t}^{*}\right)$ in every period as well as the probability $\delta$ (in every period) of incurring the exit-inducing shock. Unspecified financial frictions force entrants to borrow the amount necessary to cover the sunk entry cost from a local bank in the firm's domestic market. Since the bank has all the bargaining power, it sets the entry loan repayment in each period at $d_{t}\left(d_{t}^{*}\right)$ to extract all the firm profit. ${ }^{29}$

\footnotetext{
${ }^{26}$ Symmetry across traded goods producers within each country implies that our framework will not capture the reallocation effects of banking deregulation across firms highlighted by Bertrand, Schoar, and Thesmar (2007) and Kerr and Nanda (2007) - although it will capture the favorable effect of deregulation on firm entry that they document and that is central to our results.

${ }^{27}$ The pricing equations for foreign traded goods are $\rho_{D, t}^{*}=p_{D, t}^{*} / P_{T, t}^{*}=\left(\rho_{T, t}^{*}\right)^{-1} \mu w_{t}^{*} / Z_{t}^{*}$ and $\rho_{X, t}^{*}=p_{X, t}^{*} / P_{T, t}=$ $\left(\rho_{T, t}\right)^{-1} \tau^{*} Q_{t} \mu w_{t}^{*} / Z_{t}^{*}$, and foreign profits from domestic and export sales are $d_{D, t}^{*}=\alpha\left(\rho_{D, t}^{*}\right)^{1-\theta} C_{t}^{*} / \theta$ and $d_{X, t}^{*}=$ $\alpha Q_{t}^{-1}\left(\rho_{X, t}^{*}\right)^{1-\theta} C_{t} / \theta$, respectively.

${ }^{28}$ For simplicity, we assume identical labor productivity across traded and non-traded sectors (and across production of existing goods and creation of new products in the traded sector-see below). Productivity differences between traded and non-traded sectors would not alter our main results.

${ }^{29}$ The assumption that banks have all the bargaining power and are able to extract all the profit simplifies the model solution substantially. Relative to a debt contract, it is not necessary to keep track of outstanding loan amounts for each cohort of firms, making it possible to treat firms of different vintages equally. To the extent that a debt contract (or other contracts between banks and firms) does not alter the fact that financial deregulation facilitates firm access to finance, the key mechanisms of our model would still operate, and the main results would not be affected.
} 
There is a number $H$ of forward looking banks in the home country, which compete in Cournot fashion over the number of loans issued. Each bank takes the decisions of its competitors as given. Bank $h$ has $N_{t}(h)$ producing firms in its portfolio and decides simultaneously with other banks on the number of entrants to fund, $N_{E, t}(h)$, taking into account the post entry firm profit maximization as each firm sets optimal prices for its product. ${ }^{30,31}$

We assume that entrants at time $t$ only start producing at time $t+1$, which introduces a oneperiod time-to-build lag in the model. The exogenous exit shock occurs at the very end of the time period (after production and entry). A proportion of new entrants will therefore never produce. The bank does not know which firms will be hit by the exogenous exit shock $\delta$ at the very end of period $t$. The timing of entry and production implies that the number of firms in bank $h$ 's portfolio during period $t$ is given by $N_{t}(h)=(1-\delta)\left(N_{t-1}(h)+N_{E, t-1}(h)\right)$. Then, the number of producing home firms in period $t$ is $N_{t}=(1-\delta)\left(N_{t-1}+N_{E, t-1}\right)$, where $N_{t}=\sum_{h \in H} N_{t}(h)$, and the number of home entrants is $N_{E, t}=\sum_{h \in H} N_{E, t}(h) .{ }^{32}$ As in Bilbiie, Ghironi, and Melitz (2007) and Stebunovs (2008), the number of producing firms in period $t$ is an endogenous state variable that behaves like physical capital in standard real business cycle models.

The Euler equation for household holdings of shares in the bank fund implies that the objective function for bank $h$ is $E_{t} \sum_{s=t}^{\infty} \beta^{s-t}\left(C_{s} / C_{t}\right)^{-\gamma} \pi_{s}(h)$, which the bank maximizes with respect to $\left\{N_{s+1}(h)\right\}_{s=t}^{\infty}$ and $\left\{N_{E, s}(h)\right\}_{s=t}^{\infty}$. Bank $h$ 's profit is $\pi_{t}(h)=N_{t}(h) d_{t}+B_{t+1}(h)-\left(w_{t} / Z_{t}\right) N_{E, t}(h)-$ $\left(1+r_{t}\right) B_{t}(h)$, where $d_{t} N_{t}(h)$ is the revenue from bank $h$ 's portfolio of $N_{t}(h)$ outstanding loans (or producing firms), $B_{t+1}(h)$ denotes household deposits into bank $h$ entering period $t+1$ (so that $\left.B_{t+1}=\sum_{h \in H} B_{t+1}(h)\right),\left(w_{t} / Z_{t}\right) N_{E, t}(h)$ is the amount lent to $N_{E, t}(h)$ entrants, and $\left(1+r_{t}\right) B_{t}(h)$ is the principal and interest on the previous period's deposits. We assume that banks accrue revenues after firm entry has been funded and then rebate profits to the mutual fund owned by households. Hence, bank $h$ 's balance sheet constraint is $B_{t+1}(h)=\left(w_{t} / Z_{t}\right) N_{E, t}(h)$. In solving its optimization problem, bank $h$ takes aggregate consumption, wages, and the interest rate as given.

The first-order condition with respect to $N_{t+1}(h)$ yields the Euler equation for the value of a firm to bank $h, q_{t}(h)$, which involves a term capturing the bank's internalization of the profit

\footnotetext{
${ }^{30}$ As will become clear later, this is not exactly the static Cournot model as not only the value of entrants, but also the value of incumbents depends on the number of entrants.

${ }^{31}$ If we interpret the number of firms as the number of production lines in the economy, we can think of a bank as the headquarters of a multiproduct firm. Headquarters collect financial resources from households (under perfect competition) and decide how many products their firm produces (competing with other headquarters in Cournot fashion). Decisions on employment and prices are delegated to the product-line level, but headquarters take into account product-line behavior in their decisions.

${ }^{32}$ Similarly, the number of foreign firms during period $t$ is given by $N_{t}^{*}=(1-\delta)\left(N_{t-1}^{*}+N_{E, t-1}^{*}\right)$.
} 
destruction externality (PDE) generated by firm entry: ${ }^{33}$

$$
q_{t}(h)=\beta E_{t}\left\{\left(\frac{C_{t+1}}{C_{t}}\right)^{-\gamma}[d_{t+1}+\underbrace{N_{t+1}(h) \frac{\partial d_{t+1}}{\partial N_{t+1}} \frac{\partial N_{t+1}}{\partial N_{t+1}(h)}}_{\text {Internalization of PDE }}+(1-\delta) q_{t+1}(h)]\right\} .
$$

The bank internalizes the effect of entry on firm profits through the effect of entry on the domestic and export relative prices $\rho_{D, t}$ and $\rho_{X, t}$. Firm entry reduces firm size and profits, and hence decreases the repayments to the bank. The bank internalizes only the effects of the entry it funds. Hence, $N_{t+1}(h)$ multiplies the profit destruction externality, $\left(\partial d_{t+1} / \partial N_{t+1}\right)\left(\partial N_{t+1} / \partial N_{t+1}(h)\right){ }^{34}$

The first-order condition with respect to $N_{E, t}(h)$ defines a firm entry condition, which holds with equality as long as the number of entrants, $N_{E, t}(h)$, is positive. We assume that macroeconomic shocks are small enough for this to hold in every period. Entry occurs until the value of an additional producer to the bank, $q_{t}(h)$, is equalized with the expected, discounted entry cost, given by the deposit principal and the interest to be paid back at $t+1$ :

$$
q_{t}(h)=\frac{\beta}{1-\delta}\left(1+r_{t+1}\right) \frac{w_{t}}{Z_{t}} E_{t}\left(\frac{C_{t+1}}{C_{t}}\right)^{-\gamma}=\frac{1}{1-\delta} \frac{w_{t}}{Z_{t}}
$$

where the second equality follows from the household's Euler equation for deposits. The cost of creating a firm to be repaid at $t+1$ is known with certainty as of period $t$. As there is no difference between marginal and average $q_{t}(h)$ (the bank's valuation of a marginal new entrant coincides with its valuation of an incumbent), firm entry reduces not only the value of entering firms, but also the value of incumbents until the value of all firms is equalized with the sunk entry cost (adjusted by

\footnotetext{
${ }^{33}$ In Bilbiie, Ghironi, and Melitz (2007), firm entry is determined by the stock market value of a firm at time $t$, which reflects the probability $1-\delta$ that the firm will generate profit and be priced in the next period. Here, $q_{t}(h)$ is the value to the bank of an additional firm producing at $t+1$ (recall that the first-order condition is taken with respect to $N_{t+1}(h)$, which is the number of firms in the bank's portfolio that produce at $\left.t+1\right)$. Thus, $q_{t}(h)$ is computed under the assumption that the firm does produce at $t+1$, and the entry loan repayment, $d_{t+1}$, is not multiplied by $1-\delta$. On the other hand, $q_{t+1}(h)$ is multiplied by $1-\delta$ because the firm may be hit by the exit inducing shock at the end of period $t+1$.

${ }^{34}$ Consider profits from domestic sales: $d_{D, t}=\alpha\left(\rho_{D, t}\right)^{1-\theta} C_{t} / \theta$, with $\rho_{D, t}=\left(\rho_{T, t}\right)^{-1} \mu w_{t} / Z_{t}$. The price index for traded goods in the home country implies $1=N_{t}\left(\rho_{D, t}\right)^{1-\theta}+N_{t}^{*}\left(\rho_{X, t}^{*}\right)^{1-\theta}$, or $\rho_{D, t}=\left(N_{t}\right)^{\frac{1}{\theta-1}}\left[1-N_{t}^{*}\left(\rho_{X, t}^{*}\right)^{1-\theta}\right]^{\frac{1}{1-\theta}}$. An increase in the number of domestic producers thus decreases $d_{D, t}$ by

$$
\frac{\partial d_{D, t}}{\partial N_{t}} \frac{\partial N_{t}}{\partial N_{t}(h)}=-\frac{\alpha}{\theta} \frac{1-N_{t}^{*}\left(\rho_{X, t}^{*}\right)^{1-\theta}}{N_{t}^{2}} C_{t}
$$

and it is straightforward to verify that the derivative of $d_{D, t+1} N_{t+1}(h)$ with respect to $N_{t+1}(h)$ is given by $\left(1-N_{t+1}(h) / N_{t}\right) d_{D, t+1}$. Under symmetry across banks, this reduces to $(1-1 / H) d_{D, t+1}$ (see below). A similar reasoning applies to export profits.
} 
a premium for the risk of firm death). ${ }^{35}$

Since all banks are identical, we impose symmetry to obtain the Nash equilibrium. The equation for firm value, $q_{t}$, becomes:

$$
q_{t}=\beta E_{t}\left\{\left(\frac{C_{t+1}}{C_{t}}\right)^{-\gamma}\left[\left(1-\frac{1}{H}\right) d_{t+1}+(1-\delta) q_{t+1}\right]\right\}
$$

The parameter $H$ plays the same role in the banking market that $\theta$ plays in the goods market. At one extreme, $H=1$ or absolute bank monopoly, equation (2) implies that there is no entry as the marginal (and average) return from funding an entrant is zero: The portfolio expansion effect is totally offset by profit destruction. ${ }^{36}$ The economy is starved of firm entry - and thus, eventually, of any activity. ${ }^{37}$ Bank market power decreases as $H$ increases. At the other extreme, $H \rightarrow \infty$, equation (2) simplifies to the usual asset pricing equation of a perfectly competitive market.

Equation (2) allows us to relate our results on the effects of bank monopoly power on firm creation to Hayashi's (1982) results on the consequences of firm monopoly power for capital accumulation. Solving (2) forward yields:

$$
q_{t}=\left(1-\frac{1}{H}\right) E_{t} \sum_{s=t+1}^{\infty} \beta^{s-t}(1-\delta)^{s-(t+1)}\left(\frac{C_{s}}{C_{t}}\right)^{-\gamma} d_{s}=\left(1-\frac{1}{H}\right) q_{t}^{A}
$$

where $q_{t}^{A} \equiv E_{t} \sum_{s=t+1}^{\infty} \beta^{s-t}(1-\delta)^{s-(t+1)}\left(C_{s} / C_{t}\right)^{-\gamma} d_{s}$. With an alternative interpretation of the concepts of average and marginal $q$ in our model, $q_{t}^{A}$ corresponds to the average $q$ of Hayashi (1982): $q_{t}^{A}$ would be the valuation of an additional firm (or unit of capital) producing at time $t+1$ generated by a perfectly competitive financial market (for instance, by a competitive market for shares in firms). As demonstrated by Hayashi, the existence of monopoly power induces a discrepancy between average $q$ and marginal $q$ - the measure of $q$ that determines decisions. In our model, monopoly power in banking results in a proportional mark-down $((H-1) / H)$ of the value of firms to the bank relative to the competitive valuation (much as monopoly power in production

\footnotetext{
${ }^{35}$ The first-order condition with respect to the number of entrants in period $t$ recognizes the fact that some of these entrants will be hit by the exit shock and will not produce and repay the loan at $t+1$. To compensate the bank for the risk of entrant death, the entry condition requires that $q_{t}(h)$ be higher than the entry cost $w_{t} / Z_{t}$ by the factor $1 /(1-\delta)$.

${ }^{36}$ When $H=1$, equation (2) becomes $q_{t}=\beta(1-\delta) E_{t}\left[\left(C_{t+1} / C_{t}\right)^{-\gamma} q_{t+1}\right]$. This is a contraction mapping because of discounting, and by forward iteration under the assumption $\lim _{T \rightarrow \infty}(\beta(1-\delta))^{T} E_{t} q_{t+T}=0$ (the value of firms is zero when reaching the terminal period), the only stable solution is $q_{t}=0$, which implies $N_{E, t}=0$.

${ }^{37} N_{t}$ will fall to 0 over time if the economy had started with higher $H$ and a positive number of firms. This starvation of the economy would not happen if we assumed that the single monopolist bank takes into account its influence on aggregate consumption. This would be reminiscent of the "Ford effect" described in D'Aspremont, Ferreira, and Gerard-Varet (1996).
} 
of goods results in a proportional markup $(\theta-1) / \theta$ relative to competitive pricing and would induce marginal $q$ to be lower than average $q$ if firms accumulated capital). As in Hayashi's capital accumulation model, the discrepancy between average and marginal $q$ disappears as the economy approaches the competitive benchmark $(H \rightarrow \infty)$. Monopoly power causes marginal $q$ to be below average $q$ because additional firm creation (or capital accumulation) conflicts with a monopolist's incentive to reduce supply relative to the competitive benchmark in order to generate higher profit. The results of our model thus parallel those of traditional theory of capital accumulation.

Although the model does not feature an explicit bank markup, we can define a measure of ex post bank markup as $\mu_{B, t} \equiv d_{t} N_{t} /\left(q_{t} N_{t+1}\right)-r_{t}$. The ratio $d_{t} N_{t} /\left(q_{t} N_{t+1}\right)$ measures the relative return from funding a marginal (and average) firm. Similar equations and bank markup definition hold abroad. ${ }^{38}$

\section{Aggregate Accounting and Balanced Trade}

Aggregating the budget constraint (1) across home households and imposing the equilibrium conditions $x_{t+1}=x_{t}=1$ and $B_{t+1}=\left(w_{t} / Z_{t}\right) N_{E, t}$ yields the aggregate accounting equation $C_{t}+B_{t+1}=d_{t} N_{t}+w_{t} L$. Consumption in each period must equal labor income plus investment income net of the cost of investing in new firms. Since this cost, $B_{t+1}=\left(w_{t} / Z_{t}\right) N_{E, t}$, is the value of home investment in new firms, aggregate accounting also states the familiar equality of spending (consumption plus investment) and income (labor plus dividend). The right-hand side of the aggregate accounting equation defines GDP from the income side of the economy; the left-hand side defines GDP from the spending side. We denote GDP with $Y_{t}$ below.

To close the model, observe that financial autarky implies balanced trade: The value of home exports must equal the value of foreign exports. Hence, $Q_{t} N_{t}\left(\rho_{X, t}\right)^{1-\theta} C_{t}^{*}=N_{t}^{*}\left(\rho_{X, t}^{*}\right)^{1-\theta} C_{t}$. As in Ghironi and Melitz (2005), balanced trade under financial autarky implies labor market clearing. ${ }^{39}$

\footnotetext{
${ }^{38}$ An alternative definition of bank markup would be $\mu_{B, t} \equiv d_{t} N_{t} /\left(q_{t-1} N_{t}\right)-r_{t}=d_{t} / q_{t-1}-r_{t}$. In this definition, $q_{t-1}$ is the $t-1$ value to the bank of an additional firm producing at $t$ (whose entry was funded at $t-1$ ), $d_{t}$ is the realized return that this same firm generates. The benchmark definition in the main text compares the return from firms that were funded in period $t-1$ (and earlier) to the value to the bank of firms producing at $t+1$ and funded in period $t$ (i.e., there is a discrepancy in the timing of entry funding at numerator and denominator of $d_{t} N_{t} /\left(q_{t} N_{t+1}\right)$ ). The advantage of the alternative definition is that, by focusing on "the same firm," it provides a more accurate measure of the return from funding an entrant. However, the benchmark definition is closer to empirical measures of bank interest margins. Importantly, both definitions imply countercyclical responses of the bank markup to shocks. Moreover, the definitions are identical in steady state. Since we only use the steady-state bank markup for calibration purposes, which definition we use makes no difference for our results.

${ }^{39}$ Labor market equilibrium requires that the total amount of labor employed in the production of goods and in creation of new firms must be equal to aggregate labor supply: $L=(\theta-1) d_{t} N_{t} / w_{t}+N_{E, t} / Z_{t}+(1-\alpha) C_{t} /\left(Z_{t} \rho_{N, t}\right)$.
} 


\section{Model Summary}

Table 1 summarizes the main equilibrium conditions of the model. The equations in the table constitute a system of 29 equations in 29 endogenous variables: $r_{t+1}, w_{t}, d_{t}, \pi_{t}, q_{t}, N_{E, t}, v_{t}, \rho_{D, t}$, $\rho_{X, t}, \rho_{T, t}, \rho_{N, t}, N_{t+1}, B_{t+1}, C_{t}, r_{t+1}^{*}, w_{t}^{*}, d_{t}^{*}, \pi_{t}^{*}, q_{t}^{*}, N_{E, t}^{*}, v_{t}^{*}, \rho_{D, t}^{*}, \rho_{X, t}^{*}, \rho_{T, t}^{*}, \rho_{D, t}^{*}, N_{t+1}^{*}, B_{t+1}^{*}, C_{t}^{*}$, $Q_{t}$. Of these endogenous variables, six are predetermined as of time $t$ : the total numbers of firms at home and abroad, $N_{t}$ and $N_{t}^{*}$, the risk-free interest rates, $r_{t}$ and $r_{t}^{*}$, and the deposits, $B_{t}$ and $B_{t}^{*}$. Additionally, the model features two exogenous variables: the aggregate productivities $Z_{t}$ and $Z_{t}^{*}$. We model domestic bank market integration as a one-time, permanent increase in the number of home banks, $H .^{40}$

\section{Interstate Banking and the Real Exchange Rate}

This section discusses real exchange rate determination in our model and the mechanism for appreciation following banking deregulation. For this purpose, it is useful to introduce the distinction between welfare-consistent and data-consistent price indexes as in Ghironi and Melitz (2005).

Up to now, we have used a definition of the real exchange rate, $Q_{t} \equiv \varepsilon_{t} P_{t}^{*} / P_{t}$, computed using welfare-based price indexes $\left(P_{t}\right.$ and $\left.P_{t}^{*}\right)$. Under C.E.S. product differentiation, it is well-known that price indexes can be decomposed into components reflecting average prices and product variety. In our benchmark model, domestic and foreign price indexes for tradable goods can be decomposed as $P_{T, t}=\left(N_{t}+N_{t}^{*}\right)^{1 /(1-\theta)} \tilde{P}_{T, t}$ and $P_{T, t}^{*}=\left(N_{t}+N_{t}^{*}\right)^{1 /(1-\theta)} \tilde{P}_{T, t}^{*}$, respectively, where the sum $N_{t}+N_{t}^{*}$ reflects product variety available in the two economies, and $\tilde{P}_{T, t}$ and $\tilde{P}_{T, t}^{*}$ are the average nominal prices for all varieties sold in the two countries. The consumption-based price indexes then can be decomposed as $P_{t}=\left(N_{t}+N_{t}^{*}\right)^{\alpha /(1-\theta)} \tilde{P}_{t}$ and $P_{t}^{*}=\left(N_{t}+N_{t}^{*}\right)^{\alpha /(1-\theta)} \tilde{P}_{t}^{*}$, where $\tilde{P}_{t}$ and $\tilde{P}_{t}^{*}$ are the average nominal price levels in the two countries. As noted in Ghironi and Melitz (2005), these average prices $\left(\tilde{P}_{t}\right.$ and $\left.\tilde{P}_{t}^{*}\right)$ correspond much more closely to empirically measured CPIs than the welfare-based indexes. ${ }^{41}$ Thus, we define $\tilde{Q}_{t}=\varepsilon_{t} \tilde{P}_{t}^{*} / \tilde{P}_{t}$ as the theoretical counterpart to the empirical real exchange rate - since the latter relates CPI levels best represented by $\tilde{P}_{t}$ and $\tilde{P}_{t}^{*}$.

In our benchmark model with exogenously non-traded goods, the welfare-based real exchange

As in Ghironi and Melitz (2005) and Bilbiie, Ghironi, and Melitz (2007), there are labor market dynamics, as labor is reallocated between production of existing goods and creation of new ones in response to shocks.

${ }^{40}$ Since this is the only change we allow in the number of banks, we do not denote the latter with a time subscript to economize on notation.

${ }^{41}$ This is so because adjustment for variety in CPI data (when it happens) does not happen at the frequency captured by periods in our model. Even more importantly, adjustment for variety in CPI data is not tied to the specific preference specification that we adopt. 
rate, $Q_{t}$, and the data-consistent real exchange rate, $\tilde{Q}_{t}$, coincide:

$$
\tilde{Q}_{t}=\frac{\varepsilon_{t} \tilde{P}_{t}^{*}}{\tilde{P}_{t}}=\frac{\left(N_{t}+N_{t}^{*}\right)^{-\alpha /(1-\theta)} \varepsilon_{t} P_{t}^{*}}{\left(N_{t}+N_{t}^{*}\right)^{-\alpha /(1-\theta)} P_{t}}=\frac{\varepsilon_{t} P_{t}^{*}}{P_{t}}=Q_{t} .
$$

The reason is that (differently from Ghironi and Melitz, 2005) consumers have access to the same set of tradable (and traded) goods in the two countries, and they attach identical weights to nontradable consumption. ${ }^{42}$

Using the price index equations, we obtain:

$$
Q_{t}=\left(T O L_{t}\right)^{1-\alpha}\left[\frac{\frac{N_{t}^{*}}{N_{t}}\left(T O L_{t}\right)^{1-\theta}+\tau^{1-\theta}}{1+\frac{N_{t}^{*}}{N_{t}}\left(\tau^{*} T O L_{t}\right)^{1-\theta}}\right]^{\frac{\alpha}{1-\theta}}
$$

where, following Ghironi and Melitz (2005), we defined the terms of labor $T O L_{t} \equiv \varepsilon_{t}\left(W_{t}^{*} / Z_{t}^{*}\right) /\left(W_{t} / Z_{t}\right)$. The terms of labor measure the relative cost of effective labor across countries. ${ }^{43} \mathrm{~A}$ decrease in $T O L_{t}$ indicates an appreciation of home effective labor relative to foreign. Note that, absent trade $\operatorname{costs}\left(\tau=\tau^{*}=1\right)$, the real exchange rate reduces to $Q_{t}=\left(T O L_{t}\right)^{1-\alpha}$, reflecting the presence of non-traded goods with weight $1-\alpha$ in consumption.

Dropping time subscripts to denote a variable's level in steady state, we assume $Z=Z^{*}=1$. Assume further that the number of banks is equal in the two countries in the initial steady state $\left(H=H^{*}\right)$ and that $\tau=\tau^{*}$ and $L=L^{*}=1$. The model then features a unique, symmetric steady state with $Q=T O L=1$, and log-linearizing equation (3) around the steady state yields:

$$
\mathrm{Q}_{t}=\left(1-\alpha \frac{2 \tau^{1-\theta}}{1+\tau^{1-\theta}}\right) \mathrm{TOL}_{t}+\frac{\alpha\left(1-\tau^{1-\theta}\right)}{(\theta-1)\left(1+\tau^{1-\theta}\right)}\left(\mathrm{N}_{t}-\mathrm{N}_{t}^{*}\right)
$$

where we use sans serif fonts to denote percentage deviations from the steady state. ${ }^{44}$ It is possible to verify that the coefficients of $\mathrm{TOL}_{t}$ and $\mathrm{N}_{t}-\mathrm{N}_{t}^{*}$ in this equation are strictly positive (as long as $\tau>1$ ). An appreciation of home effective labor relative to foreign induces real exchange rate appreciation. In the absence of trade costs, this is motivated by an increase in the relative price of the non-traded good. Trade costs strengthen the effect of the terms of labor on the real exchange rate ( $\operatorname{since} 2 \tau^{1-\theta}<1+\tau^{1-\theta}$ ) by causing the appreciation of the former to induce an increase also in

\footnotetext{
${ }^{42}$ All goods are tradable in Ghironi and Melitz (2005); some are endogenously non-traded in equilibrium. This implies that different sets of tradable varieties are available to consumers at home and abroad.

${ }^{43}$ This is related to the double factorial terms of trade. The two concepts are distinct because our measure adjusts for the productivity of all labor, not just the productivity in the traded sectors.

${ }^{44}$ The solution for the steady-state levels of selected variables is in the Appendix.
} 
the relative price of home traded goods. An increase in the number of home traded goods relative to foreign induces the real exchange rate to depreciate. The reason is that the number of varieties on which home households are not paying trade costs rises, with a positive welfare effect. ${ }^{45}$ The empirically plausible restriction $\theta>3 / 2$ is sufficient for the coefficient of $\mathrm{TOL}_{t}$ to be strictly larger than the coefficient of $\mathrm{N}_{t}-\mathrm{N}_{t}^{*}$ in equation (4). ${ }^{46}$

Consider now a permanent increase in the number of home banks $H$ (holding the number of foreign banks constant). Reduced monopoly power induces home banks to finance a larger number of entrants. This amounts to a decrease in effective entry costs facing firms. ${ }^{47}$ From the perspective of prospective entrants, relative to the old steady state, the decrease in monopoly power of home banks makes the home economy a more attractive location. Absent any change in the relative cost of effective labor $\left(T O L_{t}\right)$, all new firms would only enter the home economy (there would be no new entrants into foreign). Thus, in the new long-run equilibrium, home effective labor must appreciate $\left(T O L_{t}\right.$ must decrease) in order to keep the foreign traded sector from disappearing. ${ }^{48}$ It is precisely the entry of a larger number of firms into home that puts pressure on home labor demand and induces the terms of labor to appreciate. In turn, this causes real exchange rate appreciation as described above. As we show below, for plausible parameter values, the terms of labor term prevails on the variety term in equation (4), implying that an economy with permanently more competitive banking (relative to its trading partners) has a permanently appreciated real exchange rate. $^{49}$

In the Appendix, we present a version of the model in which there is no non-traded good, but preferences for tradables are characterized by a bias in favor of domestically produced goods. In this case, the welfare-based and data-consistent real exchange rates $Q_{t}$ and $\tilde{Q}_{t}$ no longer coincide,

${ }^{45}$ The portion $\alpha /(\theta-1)$ of the coefficient of $\mathrm{N}_{t}-\mathrm{N}_{t}^{*}$ reflects the welfare benefit of additional traded goods.

${ }^{46}$ If there are no non-traded goods $(\alpha=1)$, equation (4) becomes

$$
\mathbf{Q}_{t}=\frac{1-\tau^{1-\theta}}{1+\tau^{1-\theta}} \mathrm{TOL}_{t}+\frac{1-\tau^{1-\theta}}{(\theta-1)\left(1+\tau^{1-\theta}\right)}\left(\mathrm{N}_{t}-\mathbf{N}_{t}^{*}\right)
$$

and, of course, PPP holds $\left(Q_{t}=1\right)$ if there are no trade costs.

${ }^{47}$ Relative to the deregulation scenario studied in Ghironi and Melitz (2005) and Bilbiie, Ghironi, and Melitz (2007), in which deregulation is modeled as an exogenous reduction in the sunk entry cost that entrants must pay, here- as in Stebunovs (2008) - banking deregulation lowers the financial barrier to entry erected by banks for given size of the exogenous sunk cost. The effects on firm behavior are intuitively similar.

${ }^{48}$ Absent entry into the foreign country, the number of foreign traded firms would steadily decrease with the death shock. Absent a traded sector, the foreign economy could not generate revenue with which to pay for imports from home.

${ }^{49}$ Terms of labor dynamics are also the key determinant of the terms of trade in our model. The terms of trade are given by $T_{t} \equiv \varepsilon_{t} p_{X, t} / p_{X, t}^{*}=\left(\tau / \tau^{*}\right) T O L_{t}^{-1}$. Hence, appreciation of the terms of labor implies an improvement in the terms of trade. 
and it is:

$$
Q_{t}=\left[\frac{\alpha N_{t}+(1-\alpha) N_{t}^{*}}{\alpha N_{t}^{*}+(1-\alpha) N_{t}}\right]^{\frac{1}{\theta-1}} \tilde{Q}_{t}
$$

where $\alpha \in(1 / 2,1)$ now denotes the weight of domestic goods in consumption. Importantly, $Q_{t}$ and $\tilde{Q}_{t}$ need not move in the same direction following shocks. As we illustrate in the Appendix, $T O L_{t}$ remains the main determinant of $\tilde{Q}_{t}$, so that banking deregulation continues to induce appreciation of the data-consistent real exchange rate. However, the same banking deregulation can now induce the welfare-based real exchange rate to depreciate. Suppose this is indeed the case: $\tilde{Q}_{t}$ falls (driven by $T O L_{t}$ ) and $Q_{t}$ rises (because $N_{t}$ increases by more than $N_{t}^{*}$ ). The intuition for this result is straightforward and hinges on the welfare gains from increased product variety: Even if average prices are higher in the home country, home agents are better off (on welfare grounds) spending a given nominal amount at home because they have access to a larger number of goods toward which their preferences are biased.

To conclude this section, we note that the results and intuitions we mentioned do not depend on the assumption of financial autarky. Equations (3)-(5) hold also when households can hold deposits abroad (or under any other assumption on international asset markets), and terms of labor and variety remain the fundamental determinants of real exchange rate dynamics.

\section{Interstate Banking and Macroeconomic Dynamics}

In this section, we substantiate the results and intuitions of Section 3 by means of a numerical example, which allows us to characterize the full response path of the home and foreign economy to home banking deregulation from the impact period of the shock to the new long run. For this purpose, we log-linearize the system in Table 1 around the initial, symmetric steady state under assumptions of log-normality and homoskedasticity

\section{Calibration}

We calibrate parameters as follows. We interpret periods as quarters and set $\beta=.99$ and $\gamma=1$, both standard choices for quarterly business cycle models. ${ }^{50}$ We set the size of the exogenous firm

\footnotetext{
${ }^{50}$ The choice of log utility from consumption is motivated by consistency with the elastic labor supply case below. King, Plosser, and Rebelo (1988) show that under separable preferences, log utility from consumption ensures that income and substitution effects of real wage variation on effort cancel out in steady state. This guarantees constant steady-state effort and would be necessary for balanced growth if the model featured trend productivity growth.
} 
exit shock $\delta=.025$ to match the U. S. empirical level of 10 percent job destruction per year. ${ }^{51}$ We use the value of $\theta$ from Bernard, Eaton, Jensen, and Kortum (2003) and set $\theta=3.8$, which was calibrated to fit U.S. plant and macro trade data. ${ }^{52}$ We postulate that $\tau=\tau^{*}=1.33$, which is in line with Obstfeld and Rogoff (2001). ${ }^{53}$ Given the trade cost, we calibrate the share of tradable goods in consumption to match the average 12 percent U.S. import share of GDP. ${ }^{54}$ This results in $\alpha=.397$. As noted above, we set labor effort, $L=L^{*}$, and steady-state productivity, $Z=Z^{*}$, equal to 1 without loss of generality. These parameters determine the size of economy, but leave dynamics unaffected.

With respect to banking, we set the initial steady-state number of banks $H=H^{*}$ such that it implies a bank markup of about 10 percentage points. To determine the size of the banking deregulation shock, we calculate the change in $H$ that induces a 12 percent long-run increase in the number of firms in home country. This choice is based on the evidence from the empirical finance literature: Using the new business incorporations series compiled by Dun and Bradstreet Corporation, Black and Strahan (2002) find that the number of new incorporations per capita rose by 3.8 percent following the removal of restrictions on intrastate branching; the number of new incorporations per capita rose by another 7.9 percent following the removal of restrictions on interstate banking. Hence, the move from pervasive segmentation (no branching or interstate banking) to integrated banking (branching and interstate banking) increased the number of nonfinancial establishments by 11.7 percentage points. Using the County Business Patterns series compiled by the Census Bureau, Cetorelli and Strahan (2006) find that the transition to interstate banking and the associated increase in banking competition increased the number of non-financial establishments by 11.6 percent and reduced establishment size by 12.3 percent in the external-

\footnotetext{
${ }^{51}$ Empirically, job destruction is induced by both firm exit and contraction. We include the latter portion of job destruction in the exit shock in our model, consistent with interpreting productive units also as production lines within potentially multi-product firms. The fraction of firm closures and bankruptcies over the total number of firms reported by the U.S. Small Business Administration - consistently around 10 percent per year over the recent years - yields the same calibration.

${ }^{52}$ It may be argued that the value of $\theta$ results in a steady-state markup that is too high relative to the evidence. However, it is important to observe that, in models without any fixed cost, $\theta /(\theta-1)$ is a measure of both markup over marginal cost and average cost. In our model with entry costs, free entry ensures that firms earn zero profits net of the entry cost. This means that firms price at average cost (inclusive of the entry cost). Thus, although $\theta=3.8$ implies a fairly high markup over marginal cost, our parametrization delivers reasonable results with respect to pricing and average costs. The main qualitative features of the impulse responses below are not affected if we set $\theta=6$, resulting in a 20 percent markup of price over marginal cost as in Rotemberg and Woodford (1992) and several other studies.

${ }^{53}$ Among other things, trade costs include tariffs, non-tariff barriers, and transport costs. As Obstfeld and Rogoff (2001) note, it is likely that simple estimates of average transport costs grossly understate average $\tau$ across all goods in the economy (due to substitution effects). Anderson and van Wincoop (2004) estimate international trade costs in the range of 40 to 70 percent ad-valorem tax equivalent.

${ }^{54}$ The steady-state import share of GDP is $\alpha N^{*}\left(\rho_{X}^{*}\right)^{1-\theta} C / Y$.
} 
finance-dependent sectors relative to non-dependent sectors. ${ }^{55,56}$

\section{Impulse Responses}

Figure 1 shows selected responses (percent deviations from steady state) to a permanent banking deregulation in the home economy. The number of quarters after the shock is on the horizontal axis. Consider first the long-run effects in the new steady state. These substantiate the discussion in Section 3. With the fall in bank monopoly power, the home economy draws a permanently higher number of entrants, which translates into a permanently higher number of producers and generates increased labor demand and upward pressure on wages. This induces $T O L_{t}$ to appreciate, causing appreciation of the real exchange rate $Q_{t}$. The less regulated economy exhibits higher prices relative to its trading partner. ${ }^{57}$ Consumption (and welfare) increase at home and abroad, due to the access to a larger range of (home) tradable goods.

We now describe the transitional dynamics in response to the permanent deregulation. Absent sunk entry costs, and the associated time-to-build lag before production starts, the number of producing firms $N_{t}$ would immediately adjust to its new steady-state level. Sunk costs and timeto-build transform $N_{t}$ into a state variable that behaves very much like a capital stock: The number of entrants $N_{E, t}$ represents the home consumers' investment, which translates into increases in the stock $N_{t}$ over time. ${ }^{58}$ The terms of labor steadily appreciate with the increase in home labor demand generated by entry. Home consumption decreases in the short run, as households save to finance the entry of new firms with increased deposits into banks. Foreign consumption also falls in the short run, as real depreciation of the foreign currency increases the cost of purchasing home goods. We note that the real exchange rate change unfolds slowly. Reaching the new long-run level takes over 7 years.

\footnotetext{
${ }^{55}$ Using the Longitudinal Business Database compiled by the Census Bureau, Kerr and Nanda (2006) find that interstate banking increased the entry of startups by 11 percent relative to facility expansions by existing firms. Further, they find that interstate deregulation increased the entry of small startups, with 20 or fewer employees, by 15 to 22 percent relative to facility expansions by existing firms.

${ }^{56}$ The size of the change in $H$ that we consider does not affect the qualitative features of our results. For instance, Davis, Haltiwanger, Jarmin, and Miranda (2006) document that the number of U.S. firms (both total and privately held) increased by approximately 34 percent between 1980 and 2000 . The impulse responses we present below are qualitatively unaffected if we assume a change in $H$ that causes the number of firms to increase by 30 percent in the long run, attributing most of the increase documented by Davis and coauthors to the effects of the banking deregulation.

${ }^{57}$ As noted above, if banking competitiveness is associated with economic development, this is consistent with the Harrod-Balassa-Samuelson evidence that more developed economies exhibit appreciated real exchange rates relative to their trading partners.

${ }^{58}$ The figures plot the end-of-period response of the number of firms. In other words, consistent with the model, the response plotted in each period is the response of the number of firms with which the economy enters the following period.
} 
The responses to banking deregulation are qualitatively similar when the model features home bias in preferences for tradables rather than non-traded goods. The figure can be found in the Appendix. ${ }^{59}$ The only significant difference is that the welfare-based real exchange rate appreciates in the short run, but it depreciates in the long run (while the data-consistent real exchange rate appreciates steadily). The intuition follows from the discussion in Section 3: The number of firms does not respond to deregulation on impact. Hence, $Q_{t}$ is driven by $T O L_{t}$ in the very short run, as is $\tilde{Q}_{t}$. However, as the number of home firms increases, the welfare benefit of having access to a larger number of goods toward which preferences are biased pushes $Q_{t}$ upward and eventually induces depreciation.

\section{International Deposits}

We now extend the model of the previous section to allow households to hold deposits abroad. ${ }^{60}$ We study how international deposits affect the results we have previously described and how microeconomic dynamics affect the current account in our model. Since the extension to international deposits does not involve especially innovative features relative to the financial autarky setup, we herein limit ourselves to describing its main ingredients in words and present the relevant model equations in the Appendix.

We assume that banks can supply deposits domestically and internationally. Home deposits, issued to home and foreign households, are denominated in home currency. Foreign deposits, issued to home and foreign households, are denominated in foreign currency. We maintain the assumption that nominal returns are indexed to inflation in each country, so that deposits issued by each country provide a risk-free, real return in units of that country's consumption basket. International asset markets are incomplete, as only risk-free deposits are traded across countries. We assume that agents must pay quadratic transaction fees to banks when adjusting their deposits abroad. ${ }^{61}$ These fees pin down the deterministic steady-state allocation of deposits and ensure stationary responses

\footnotetext{
${ }^{59}$ In this case, the steady-state import share of GDP is $(1-\alpha) N^{*}\left(\rho_{X}^{*}\right)^{1-\theta} C / Y$ and $\alpha=.755$ to match the 12 percent U.S. average import share. The same initial value of $H$ (1.468) results in a 10 percent bank markup, but the new value required to generate a 12 percent increase in the number of firms changes slightly.

${ }^{60}$ For simplicity, we continue to assume that banks are owned only domestically. International trade in bank equity would enhance international risk sharing in the model, but we do not expect that it would affect our main results. It would be easy to preserve market incompleteness by expanding the set of shocks in the model. Moreover, we assume that entrants must borrow from domestic banks. Therefore, even if international deposits give borrowers (indirect) access to foreign savings, the number of domestic banks represented in each locality remains the relevant measure of bank monopoly power. The assumption that entrants must borrow from domestic banks is quite plausible for small firms (as we noted above, a large portion of U.S. GDP).

${ }^{61}$ We assume that banks then rebate the revenues from deposit adjustment fees to households.
} 
of the model to non-permanent shocks. Since agents pay fees only when they adjust their deposits abroad, the steady state of the model with international deposits coincides with the steady state of the model under financial autarky. ${ }^{62}$ In particular, $\beta(1+r)=\beta\left(1+r^{*}\right)=1, B=B_{*}^{*}=w N_{E} / Z$, and $B_{*}=B^{*}=0$, where $B\left(B_{*}^{*}\right)$ is home (foreign) holdings of home (foreign) deposits, $B_{*}\left(B^{*}\right)$ is home (foreign) holdings of foreign (home) deposits, and we assumed $Z=Z^{*}$. Realistic parameter values imply that the cost of adjusting deposits has a very small impact on model dynamics, other than pinning down the deterministic steady state and ensuring mean reversion in the long run when shocks are transitory. ${ }^{63}$

In equilibrium, the markets for home and foreign deposits clear, and each country's net foreign assets entering period $t+1$ depend on interest income from deposit holdings entering period $t$, labor income, net investment income, and consumption during period $t$. The change in net foreign deposit holdings between $t$ and $t+1$ is the country's current account. Home and foreign current accounts add to zero when expressed in units of the same consumption basket. ${ }^{64}$ There are now three Euler equations in each country: the Euler equation for share holdings, which is unchanged, and Euler equations for holdings of domestic and foreign deposits. The fees for adjusting deposits abroad imply that the Euler equations for these deposits feature a term that depends on the stock of deposits - the ingredient pinning down the steady state allocation of deposits and delivering model stationarity. Euler equations for deposits in each country imply a no-arbitrage condition between deposits. In the log-linear model, this no-arbitrage condition relates (in a standard fashion) the real interest rate differential across countries to expected depreciation of the consumption-based real exchange rate. The balanced trade condition closed the model under financial autarky. Since trade is no longer balanced with international deposits, we must explicitly impose labor market clearing conditions in both countries. These conditions state that the amount of labor used in production and to cover entry costs in each country must equal labor supply in that country in each period.

As before, we analyze the response path of the real exchange rate and other key variables to a permanent banking deregulation. To do so, we log-linearize the model around its unique

\footnotetext{
${ }^{62}$ As we show in the appendix, imposing adjustment costs on deposits abroad is sufficient to pin down a unique steady state for our model.

${ }^{63}$ Devereux and Sutherland (2010) and Tille and van Wincoop (2010) develop an alternative technique for pinning down steady-state international asset portfolios. A friction of the type we consider is then needed only to ensure stationarity of net foreign assets. We use a convenient specification of adjustment costs also to pin down the steadystate allocation of deposits since our interest is in the dynamics of overall net foreign assets rather than the composition of portfolios, and we are interested in evaluating how the possibility of depositing funds abroad affects dynamics around the same steady state as under financial autarky (while the Devereux-Sutherland/Tille-van Wincoop technique would imply a different steady state).

${ }^{64}$ Net foreign assets and the current account are zero in steady state.
} 
steady state. We set the scale parameter for the deposit adjustment cost, $\eta$, to 0.0025 - sufficient to generate stationarity in response to transitory shocks (such as the productivity shocks we will consider below), but small enough to avoid overstating the role of this friction in determining the dynamics of our model.

\section{Interstate Banking and Macroeconomic Dynamics}

As under financial autarky, we consider the responses to a deregulation of home banking (a permanent increase in the number of home banks, $H$ ) such that the number of home producers increases by 12 percent in the long-run. Figure 2 shows the impulse responses. The responses of home and foreign consumption are qualitatively similar to Figure 1. Initially, households in both countries reduce consumption to finance increased producer entry in the deregulated home economy. Home runs current account deficits for two years in response to the shock, resulting in the accumulation of a persistent net foreign debt position. Home households borrow from abroad to finance higher initial investment (relative to financial autarky) in new home firms. The home household's incentive to front-load producer entry is mirrored by the foreign household's desire to invest savings in the more attractive economy. Although home consumption declines initially, it is permanently higher in the long run. Foreign consumption moves by more than in Figure 1 as foreign households initially save in the form of foreign lending and then receive income from their positive asset position. Although foreign households cannot hold shares in the mutual fund of home banks (since deposits are the only international financial asset), the return on deposit holdings is tied to the return on holdings of shares in home banks by no-arbitrage between deposits and shares within the home economy. Therefore, foreign households share the benefits of expansion in the home economy via international deposit holdings. As in the case of financial autarky, $T O L_{t}$ must decrease in the long run (home effective labor must relatively appreciate); otherwise, all new entrants would choose to locate in the home economy. The accelerated entry of new home firms financed by external borrowing induces an immediate relative increase in home labor demand, and $T O L_{t}$ immediately appreciates (as opposed to a gradual appreciation under financial autarky). Thus, the real exchange rate $Q_{t}$ also immediately appreciates. ${ }^{65}$ The opening of the economy to international deposits does not qualitatively change the mechanism that leads to real exchange rate appreciation following banking deregulation in our model. Foreign consumption and GDP increase in the long run, even

\footnotetext{
${ }^{65}$ The terms of labor and the real exchange rate overshoot their new long-run appreciated levels on impact, reflecting the effect on home labor costs of the spike in labor demand from increased business creation on impact.
} 
though the number of foreign producers is reduced by the relocation of business creation to the home country. The permanent expansion in the number of home producers more than compensates the loss in the number of foreign firms to determine the increase in long-run foreign consumption. ${ }^{66}$

\section{Persistent Current Account Deficits}

Figure 2 shows that the home country runs current account deficits for two years following the banking deregulation. U.S. current account deficits have been longer lasting in the 1980s and 1990s. However, it is easy to extend our model to generate more persistent deficits while preserving the other key results. For instance, the current account deficit is significantly more persistent if the banking deregulation is treated as an anticipated, rather than unanticipated, event. This is a plausible scenario, considering the legislative process required by the deregulation. Figure 3 presents the results when the deregulation is expected to happen two years in the future. As the figure shows, the home country starts borrowing immediately, to finance increased business creation in anticipation of the coming deregulation, and the current account deficit lasts for three years.

Another way to increase current account persistence is to assume that the entry cost depends on the number of existing firms as in Grossman and Helpman (1991). Suppose that creating a new firm requires $\left(N_{t}\right)^{\lambda}$ units of effective labor. When $\lambda<0$, there is a positive externality from the number of existing firms to entry costs. The intuition is that innovation is easier in an environment where there has been much innovation in the past. ${ }^{67}$ Figure 4 presents the responses to (unanticipated) banking deregulation in this scenario, with $\lambda=-.5$ for illustrative purposes. This version of the model results in a significantly more persistent deficit, lasting over 30 quarters. Since current entry reduces future entry costs, the incentive to borrow to finance firm creation is strengthened, and this propagates the deficit over time.

We have thus established two consequences of lower local monopoly power of banks: real exchange rate appreciation and external borrowing to finance increased business creation. Next, we turn to a more quantitative version of our model to study the consequences of interstate banking for macroeconomic volatility.

\footnotetext{
${ }^{66}$ The impulse responses for the model with home bias in consumption are in the appendix. As before, the main difference is in the dynamics of the welfare-consistent versus data-consistent real exchange rate, which display the same pattern as under financial autarky.

${ }^{67}$ This is the case on which Grossman and Helpman (1991) focus in their analysis of endogenous growth.
} 


\section{Interstate Banking and International Business Cycles}

We now extend the model with international deposits to incorporate countercyclical firm markups and elastic labor supply. Assuming that fluctuations in home and foreign productivity are the sources of international business cycles, this allows us to illustrate the mechanism behind the moderation of business cycle volatility generated by interstate banking in our model. This extension exploits the implications of endogenous variety by separating taste for variety and firm monopoly power, and allowing for endogenous demand elasticity and countercyclical firm markups.

The representative home household now supplies $L_{t}$ units of labor endogenously in each period. The household maximizes expected intertemporal utility from consumption and labor effort: $E_{t} \sum_{s=t}^{\infty} \beta^{s-t}\left[\log C_{s}-\chi\left(L_{s}\right)^{1+1 / \varphi} /(1+1 / \varphi)\right]$, where $\chi>0$ is the the weight of disutility of labor effort, and $\varphi>0$ is the Frisch elasticity of labor supply to wages, subject to the same budget constraint as in the previous section. The household's intertemporal optimality conditions remain the same. The only additional optimality condition is the intratemporal optimality condition for labor supply. Elastic labor supply implies that households have an extra margin of adjustment to shocks. This enhances the propagation mechanism of the model by amplifying the responses of endogenous variables with respect to the benchmark model.

To generate endogenously fluctuating markups, we now define the baskets of goods over discrete numbers of home and foreign varieties. ${ }^{68}$ The basket of tradable goods now is $C_{T, t}=$ $\left(\sum_{\omega \in \Omega} c_{t}(\omega)^{(\theta-1) / \theta}\right)^{\theta /(\theta-1)}$; hence, $P_{T, t}=\left(\sum_{\omega \in \Omega_{t}} p_{t}(\omega)^{1-\theta}\right)^{1 /(1-\theta)}$. Each producer no longer ignores the effects of its nominal domestic price, $p_{D, t}(\omega)$, on the home tradable price index, $P_{T, t}$, and the effect of its nominal export price, $p_{X, t}(\omega)$, on the foreign tradable price index, $P_{T, t}^{*} \cdot{ }^{69}$ The perceived home demand elasticity is then $\theta_{D, t}(\omega) \equiv \theta\left(1-\left(p_{D, t}(\omega) / P_{T, t}\right)^{1-\theta}\right)$ and the foreign demand elasticity is $\theta_{X, t}(\omega) \equiv \theta\left(1-\left(p_{X, t}(\omega) / P_{T, t}^{*}\right)^{1-\theta}\right)$. Note that taking into account this indirect price effect decreases the demand elasticities perceived by firm $\omega\left(\theta_{D, t}(\omega)<\theta\right.$ and $\theta_{X, t}(\omega)<\theta$; hence, it increases its monopoly power in both markets. The implied markup is $\mu_{D, t}(\omega) \equiv \theta_{D, t}(\omega) /\left(\theta_{D, t}(\omega)-1\right)$ in the domestic market and $\mu_{X, t}(\omega) \equiv \theta_{X, t}(\omega) /\left(\theta_{X, t}(\omega)-1\right)$ in the foreign market. Firms set flexible prices that reflect these different markups over marginal cost in the different markets where they sell their output. ${ }^{70}$ As before, define the relative

\footnotetext{
${ }^{68}$ An alternative way to generate endogenously fluctuating markups would be to use translog preferences with a continuum of producers as in Bilbiie, Ghironi, and Melitz (2007). Since both specifications result in countercyclical markups, we conjecture that results would be similar for our purposes.

${ }^{69}$ See Yang and Heijdra (1993) for an analysis of Dixit-Stiglitz monopolistic competition with a discrete number of producers.

${ }^{70}$ We implicitly assume that firms have the ability to segment markets, so that consumers cannot arbitrage away
} 
prices $\rho_{D, t}(\omega) \equiv p_{D, t}(\omega) / P_{T, t}, \rho_{T, t} \equiv P_{T, t} / P_{t}, \rho_{X, t}(\omega) \equiv p_{X, t}(\omega) / P_{T, t}^{*}$, and $\rho_{T, t}^{*} \equiv P_{T, t}^{*} / P_{t}^{*}$. Then, $\rho_{D, t}(\omega)=\left(\rho_{T, t}\right)^{-1} \mu_{D, t}(\omega) w_{t} / Z_{t}$ and $\rho_{X, t}(\omega)=\left(\rho_{T, t}^{*}\right)^{-1} \tau Q_{t}^{-1} \mu_{X, t}(\omega) w_{t} / Z_{t}$. Profits generated by domestic sales are $d_{D, t}(\omega)=\alpha\left(\rho_{D, t}(\omega)\right)^{1-\theta} C_{t} / \theta_{D, t}(\omega)$, and profits generated by exports are $d_{X, t}(\omega)=\alpha Q_{t}\left(\rho_{X, t}(\omega)\right)^{1-\theta} C_{t}^{*} / \theta_{X, t}(\omega)$. Since all firms are identical in equilibrium, we drop the index $\omega .^{71}$

In this version of the model, banks internalize the effect of entry on firm profits through the effect of entry on the nominal domestic price, $p_{D, t}$, and then on the home tradable price index, $P_{T, t}$, and the effect of entry on the nominal export price, $p_{X, t}$, and then on the foreign tradable price index, $P_{T, t}^{*}$. The equation for firm value, $q_{t}$, becomes:

$$
q_{t}=\beta E_{t}\left\{\left(\frac{C_{t+1}}{C_{t}}\right)^{-1}\left[\left(1-\frac{1}{H} \frac{\theta}{\theta_{D, t+1}}\right) d_{D, t+1}+\left(1-\frac{1}{H} \frac{\theta}{\theta_{X, t+1}}\right) d_{X, t+1}+(1-\delta) q_{t+1}\right]\right\} .
$$

(The derivation details are in the appendix. A similar equation holds abroad. This equation holds also in the model with home bias.) As in the benchmark model, equation (6) implies that there is no entry at the extreme $H=1$ of absolute bank monopoly: The return from funding an entrant is negative in this case, as the portfolio expansion effect is dominated by profit destruction (recall that $\theta_{D, t+1}<\theta$ and $\theta_{X, t+1}<\theta$ ). Bank monopoly power decreases as $H$ increases, and equation (6) simplifies to the familiar asset pricing equation with perfectly competitive asset pricing at the other extreme, $H=\infty$. Over the business cycle generated by an increase in productivity, as the number of firms increases, the perceived demand elasticities $\theta_{D, t}$ and $\theta_{X, t}$ increase, and markups fall. On the one hand, the fact that the ratios $\theta / \theta_{D, t+1}$ and $\theta / \theta_{X, t+1}$ are larger than one reduces bank incentives to invest in new firms. On the other hand, since firm profits are procyclical and banks own claims to these profits, the importance of the profit destruction externality falls as $\theta / \theta_{D, t+1}$ and $\theta / \theta_{X, t+1}$ decrease, strengthening bank incentives to invest.

Table 2 summarizes the main equilibrium conditions of this version of the model (showing only the equations pertaining to home variables and net foreign assets). ${ }^{72}$ We study the model predictions with Frisch elasticity $\varphi=10 .{ }^{73}$ We set the weight of the disutility of labor, $\chi$, to 1 . In

deviations from the law of one price in excess of those implied by trade costs. Since firm entry is procyclical in our model, markups are countercyclical, and their movements amplify fluctuations in firm output.

${ }^{71}$ Similar price and profit equations hold for foreign firms. Note that $\rho_{X, t}^{*}=\left(\rho_{T, t}\right)^{-1} Q_{t} \tau^{*} \mu_{X, t}^{*} w_{t}^{*} / Z_{t}^{*}$, and hence a foreign firm earns export profits $d_{X, t}^{*}=\alpha Q_{t}^{-1}\left(\rho_{X, t}^{*}\right)^{1-\theta} C_{t} / \theta_{X, t}^{*}$.

${ }^{72}$ The model with tradable goods only and home bias in consumption can be summarized by replacing the consumption price index, tradable price index, goods pricing, firm profit, and labor market clearing equations with the equations shown in the appendix.

${ }^{73}$ The case in which $\varphi \rightarrow \infty$ corresponds to linear disutility of effort and is often studied in the business cycle 
this and the following section, we set the share of tradable goods in the consumption basket, $\alpha$, to .5 , while iceberg trade costs are kept at $\tau=\tau^{*}=1.33$. The choice of $\alpha$ is dictated by difficulties in computing the model's steady state, and it implies a steady-state import share of about 18 percent. ${ }^{74}$ The other preference parameters, and the size of the exogenous exit probability $\delta$, remain the same as in the benchmark model. The calibration strategy for $H$ is the same as before. We set the pre-deregulation $H$ to imply a 10 percent bank markup. Then, a 12 percent long-run increase in the number of domestic firms pins down the size of the increase in $H$ that captures banking deregulation. We keep the steady-state home and foreign productivity levels, $Z$ and $Z^{*}$, at 1. Note that, in this version of the model, this choice not only determines the number of firms (the size of the economy ) in steady state, and hence the steady-state firm markups, but it also matters for the cyclical properties of markups. The lower steady-state productivity, the lower the number of firms, and the higher steady-state firm markups. In turn, this implies more countercyclical markups over the business cycle. The intuition is simple: When the steady-state number of firms is low (so that each of them is operating on a larger share of the market), banks have an incentive to finance more entry (as a percentage of the initial steady state) following a favorable productivity shock than when the steady-state number of firms is large. As a consequence, the markup falls by more (in percent of the initial steady state) when expansions happen around a steady state with a smaller number of firms. This effect is mirrored by household labor supply decisions. By adjusting steadystate productivity, we can affect the interplay of wealth and substitution effects in labor supply. As lower steady-state productivity leads to more countercyclical markups, and hence more procyclical wages, it generates stronger substitution effects and weaker wealth effects in labor supply in the impact response to temporary productivity shocks. For persistent enough shocks, the representative household then is willing to take advantage of temporarily high productivity by supplying more labor to increase substantially the available number of products, lower firm monopoly power, and experience significantly higher consumption in the future portion of the transition.

\section{The Responses to Banking Deregulation}

Figure 5 shows the responses to home banking deregulation. Time varying firm markups and elastic labor supply result in amplified responses of endogenous variables. Consistent with a reduction in literature.

${ }^{74}$ The lowest steady-state import share we obtained with $\tau=\tau^{*}=1.33$ was 16 percent with $\alpha$ approximately .35 . In the version of the model with tradable goods only and home bias in consumption, given $\tau=\tau^{*}=1.33$, we set the weight of home goods in the consumption basket to .797, which yields a steady-state import share of about 12 percent. 
monopoly power in the economy, home labor supply is permanently higher. Since households can now respond to the shock also by expanding their labor effort and firm markups decline, home consumption no longer falls on impact. Similarly, the response of foreign labor allows the foreign economy to enjoy increased business creation and GDP throughout the transition. As in the model with inelastic labor and constant firm markups, the terms of labor appreciate, leading to real exchange rate appreciation, and the home economy borrows to finance increased business creation. $^{75}$

\section{Productivity Shocks and Macroeconomic Dynamics}

Figure 6 illustrates the business cycle propagation properties of our model by showing the impulse responses to a transitory increase in home productivity. We assume a 1 percent innovation to home productivity with persistence .9 . The solid lines are the impulse responses to this shock around the pre-deregulation steady state, while dashes denote the impulse responses to the same shock around the post-deregulation steady state. As the responses show, the shock has no permanent effect since all endogenous variables are stationary in response to stationary exogenous shocks. However, the responses also clearly highlight the substantial persistence of key endogenous variables - well beyond the exogenous persistence of the productivity shock. For example, it takes over 10 years for the real exchange rate to return to the steady-state level.

Note the initial appreciation of the terms of labor, again motivated by the effect of increased entry of new firms into the home economy on home labor costs. Since shock persistence is relatively low (by real business cycle standards), lending abroad to smooth the consequences of a temporary, favorable shock on consumption is the main determinant of net foreign asset dynamics, and the home economy runs a current account surplus, accumulating net foreign assets above the steady state. $^{76}$

Importantly, lower bank monopoly power implies a smaller percent deviation of firm entry from the steady state, less countercyclical firm markups, and weaker substitution effects in labor supply. As a consequence of deregulation, the responses of firm entry, labor supply, consumption, investment, and aggregate output are muted in the home economy. Given the trade and financial ties with home, banking deregulation at home results in dampened fluctuations also abroad.

\footnotetext{
${ }^{75}$ As in the model with inelastic labor supply and constant firm markups, assuming that the transition to interstate banking is anticipated or introducing an externality in entry costs increases the persistence of the current account deficit. Figures for these cases are available on request.

${ }^{76}$ When the shock is more persistent, financing increased firm entry in the more productive economy becomes the main determinant of the current account, and the home economy runs a deficit in response to higher productivity.
} 
The intuition is straightforward, and related to the discussion of the consequences of changes in steady-state productivity above. Post-deregulation, the economy is populated by a larger steadystate number of firms, which are operating on a smaller share of the market and charging lower markups due to higher perceived elasticity of demand. As a consequence, when a favorable productivity shock happens, the banks' incentive to let additional firms into the economy is weakened, and we observe less business creation as a percentage of the steady-state number of firms than around the pre-deregulation steady state. In turn, this dampens markup fluctuations around the post-deregulation steady state, and it is accompanied by weaker substitution effects in labor supply and muted responses of home and foreign endogenous variables to the productivity shock.

\section{Deregulation and Moderation}

The model includes only one source of fluctuations at business cycle frequency, the shocks to aggregate productivity $Z_{t}$ and $Z_{t}^{*}$. Our interest is not in whether the model has the ability to replicate a wide range of data moments, but in studying whether the transition to interstate banking in the U.S. may have contributed in non-negligible fashion to the dampening of U.S. and international business cycle volatility in the Great Moderation years through the channel discussed above.

For this purpose, we assume that the percentage deviations of $Z_{t}$ and $Z_{t}^{*}$ from the steady state follow the bivariate process:

$$
\left[\begin{array}{c}
\mathrm{Z}_{t} \\
\mathrm{Z}_{t}^{*}
\end{array}\right]=\left[\begin{array}{cc}
\phi_{Z} & \phi_{Z Z^{*}} \\
\phi_{Z^{*} Z} & \phi_{Z^{*}}
\end{array}\right]\left[\begin{array}{c}
\mathrm{Z}_{t-1} \\
\mathrm{Z}_{t-1}^{*}
\end{array}\right]+\left[\begin{array}{c}
\xi_{t}^{Z} \\
\xi_{t}^{Z^{*}}
\end{array}\right]
$$

where the persistence parameters $\phi_{Z}$ and $\phi_{Z^{*}}$ are in the unit interval, the spillover parameters $\phi_{Z Z^{*}}$ and $\phi_{Z^{*} Z}$ are non-negative, and $\xi_{t}^{Z}$ and $\xi_{t}^{Z^{*}}$ are normally distributed, zero-mean innovations.

We consider two alternative calibrations for the process (7). First, we use the symmetrized estimate of the bivariate productivity process for the United States and an aggregate of European economies in Backus, Kehoe, and Kydland (1992) and set $\phi_{Z}=\phi_{Z^{*}}=.906$ and $\phi_{Z Z^{*}}=\phi_{Z^{*} Z}=$ .088. The latter value implies a small, positive productivity spillover across countries, such that, if home productivity rises during period $t$, foreign productivity will also increase at $t+1$. We set the standard deviation of the productivity innovations to .00852 (a .73 percent variance) and the correlation to .258 (corresponding to a .19 percent covariance) as estimated by Backus, Kehoe, and Kydland (1992). In the second parametrization, we follow Baxter (1995) and Baxter and Farr (2005), who argue that the balance of evidence is in favor of increased persistence and absence of 
spillovers, and we set the spillover parameters $\phi_{Z Z^{*}}=\phi_{Z^{*} Z}=0$ and persistence $\phi_{Z}=\phi_{Z^{*}}=.999$, leaving the variance-covariance matrix of innovations unchanged. We calculate the implied second moments of Hodrick-Prescott (HP)-filtered endogenous variables (percent deviations from steady state) using the frequency domain technique described by Uhlig (1999). ${ }^{77}$

We noted above that empirical price deflators are best represented by the average prices $\tilde{P}_{t}$ and $\tilde{P}_{t}^{*}$ in our model (as opposed to the welfare based price indexes $P_{t}$ and $P_{t}^{*}$ ). Therefore, when investigating the properties of the model in relation to the data, we focus on nominal variables deflated by the data-consistent price indexes $\tilde{P}_{t}$ and $\tilde{P}_{t}^{*}$ rather than variables in welfare-consistent units. Data-consistent, real variables are thus obtained as $X_{R, t} \equiv X_{t} P_{t} / \tilde{P}_{t}$, where $X_{t}$ is any variable in units of the consumption basket. As we previously discussed, creation of new firms is the form taken by capital accumulation in our model, and the stock of firms represents the capital stock of the economy. The measure of investment in our model is therefore. $I_{R, t}=P_{t} w_{t} N_{E, t} /\left(Z_{t} \tilde{P}_{t}\right)$ and $I_{R, t}^{*}=P_{t}^{*} w_{t}^{*} N_{E, t}^{*} /\left(Z_{t}^{*} \tilde{P}_{t}^{*}\right)$.

Table 3 presents model-generated standard deviations for key macroeconomic aggregates and the real exchange rate for both the model with non-traded goods and the model with home bias and for both calibrations of the productivity process (7). Focus on the Backus-Kehoe-Kydland parametrization first. Both versions of the model generate less volatile consumption and slightly more volatile labor effort than GDP. ${ }^{78}$ Clearly, there is excess volatility of investment - a standard finding absent an adjustment cost of the type usually introduced in business cycle models. Eliminating productivity spillovers and increasing the persistence of shocks as in the Baxter parametrization reduces the volatility across all variables - including a significant reduction in the volatility of investment - although it makes labor too smooth. Importantly, both models and both parametrization show that lower local monopoly power of banks reduces the volatility of home GDP by 9 to 11 percent. ${ }^{79}$ As suggested by Figure 6, banking deregulation moderates the cycle across all relevant macroeconomic aggregates in the home country, and it reduces the volatility of international relative prices. Foreign GDP volatility also declines in most cases (except for the Baxter parametrization of the model with home bias), while foreign consumption becomes more volatile in all cases but the Backus-Kehoe-Kydland scenario with home bias.

\footnotetext{
${ }^{77}$ As customary, we set the HP filter parameter $\lambda=1,600$.

${ }^{78}$ King and Rebelo (1999) document that the ratios of standard volatilities of consumption, labor effort, and investment to GDP in U.S. data are .74, .99, and 2.93, respectively, over the sample they consider.

${ }^{79}$ Moderation of markup volatility ensures that firm-level output fluctuations are also less volatile following banking deregulation, consistent with the evidence in Correa and Suarez (2007).
} 


\section{Conclusion}

We developed a two-country model of the domestic and external effects of removing U.S. bank market segmentation that predicts real appreciation, external borrowing, and moderation of domestic and international business cycles as joint equilibrium consequences of increased local banking competition. The key channel through which this occurs is increased business creation in the U.S. relative to the rest of the world, as potential entrants in product markets have easier access to bank finance in the less segmented market. The model provides a unified explanation of features of U.S. and international economic dynamics following the transition to interstate U.S. banking that started in the late 1970s. By focusing on the structure of banking, the reduction in the local monopoly power of banks implied by deregulation, and the incentives for producer entry, the model is consistent with a large body of evidence from the empirical finance literature.

Our paper contributes to a growing literature on the dynamics of external balances, business cycles, and international relative prices. It provides a complementary explanation of accumulation of foreign debt that highlights an additional source of cross-country asymmetry in the characteristics of financial sectors relative to those emphasized by Caballero, Fahri, and Gourinchas (2008) and Mendoza, Quadrini, and Ríos-Rull (2009). It complements Fogli and Perri (2006) by connecting external borrowing along the transition to the post-deregulation steady state to moderation of the business cycle around the new steady state, and it contributes to the study of movements in real exchange rates by pointing to a hitherto unexplored source of differential pressures on labor costs. Finally, our paper contributes to the literature on the Great Moderation by studying the role of changes in financial market structure and their domestic and international effects. While our quantitative results are merely suggestive, they point to the fact that lower local monopoly power of banks in the U.S. may have contributed to lower business cycle volatility in the Great Moderation years in a non-negligible fashion.

The mechanism we highlight in this paper is very robust. We focused on the effects of the removal of geographical segmentation of bank markets, but any form of financial market deregulation that facilitates access to finance by product market entrants would lead to real appreciation, external borrowing, and eventual business cycle moderation through the channels we discussed by lowering the effective entry barriers facing entrants. In this respect, our model provides a lens through which one can look at the consequences of financial deregulation more broadly defined as any action that facilitates access to finance. Of course, one would want to extend the model 
to incorporate heterogeneous borrower quality, asymmetric information, risk of default, and other forms of market regulation (or deregulation) to capture the crisis that begun in 2007.80 Incorporation of within-country, idiosyncratic risk would also make it possible to confront the model with the empirical results of another strand of literature in finance, which documents that U.S. banking deregulation improved risk sharing across U.S. states by facilitating access to finance for small business owners (Demyanyk, Østergaard, and Sørensen, 2007). We leave these extensions for future work, along with an exploration of optimal regulation policy and endogenous financial market development. ${ }^{81}$

\section{Appendix}

\section{A Historical Background}

\section{The Transition to Interstate Banking in the U.S.}

For decades, a myriad of state and federal laws limited where banks could operate in the U.S. As a result, the banking system was anything but national. Until the late 1970s, every state effectively barred banks from other states, so instead of one national banking system, the country had 50 banking systems, one per state (Morgan, Rime, and Strahan, 2004). Moreover, most states also prohibited branching across counties within the state, so the country had essentially as many banking systems as counties. ${ }^{82}$ State-level deregulation beginning in the late 1970s lifted restrictions on bank expansion both within and across states. By the early 1990s, almost all states had removed restrictions. The transition to truly interstate banking was completed with the passage of federal legislation by the mid 1990s.

Restrictions on banks' ability to expand within a state through branching were initially imposed by the states in the nineteenth century. Although there was some deregulation of these branching

\footnotetext{
${ }^{80}$ Note that one can view the decision to purchase a house as an entry decision (into home ownership) requiring a sunk investment of resources that must (for the most part) be borrowed from banks. Deregulation that makes access to this finance easier for households will result in more entry into home ownership and external borrowing. Household heterogeneity, asymmetric information, and debt default would then be necessary additional ingredients for a model of the recent international financial crisis that preserves the key logic of our model.

${ }^{81}$ We took the structure of banking in each country as exogenous, but there is some indication of endogeneity in the data. For example, in the late 1970s, U.S. bank branch creation turned from acyclical to countercyclical. A richer modeling of the financial sector, leading to endogenous differences in financial structures across countries in response to policy and the economy, is another promising avenue for future research.

${ }^{82}$ Banks were also shielded from competitive pressures in the deposit market. Regulation Q, the Prohibition Against the Payment of Interest on Demand Deposits, put in place by the Glass-Steagall Act of 1933, limited price competition by imposing ceilings on deposit interest rates. In the early 1980s, interest rate ceilings were largely removed, allowing banks to compete more vigorously for funds.
} 
restrictions in the 1930s, most states either prohibited branching altogether or limited branching until the 1970s. For example, Florida prohibited branch banking entirely until 1977, when banks were allowed to branch within the county where their main offices were located, and finally permitted branching statewide in 1988. Only thirteen states allowed unrestricted intrastate branching in 1974 . During the next two and a half decades, thirty-five states deregulated in waves, rather than all at once as in our simplified theoretical exercise, substantially eliminating restrictions on intrastate branching. By 1992, all but three states allowed some form of statewide branching (Jayaratne and Strahan, 1998).

Many states had allowed banking companies to expand within the state by forming multibank holding companies (MBHCs) before they allowed branch banking. By 1975, thirty-five states allowed MBHC expansion within state. Of the fifteen remaining states, all but Rhode Island relaxed MBHC restrictions between 1975 and 1992, about the same time as they relaxed branching restrictions (Jayaratne and Strahan, 1998). However, MBHCs are more costly to operate than branch banks because they require separate charters, boards of directors, and capitalization of each bank subsidiary. ${ }^{83}$

In addition to facing restrictions on within-state branching, the Douglas Amendment to the 1956 Bank Holding Company Act effectively prohibited MBHCs from establishing or purchasing bank subsidiaries outside the state where they were headquartered unless the target bank's state authorized it. Since no state allowed such transactions in 1956, the amendment effectively barred interstate banking. States had the option to allow out-of-state MBHCs to enter, but none exercised it until 1978, when Maine permitted such transactions, and Alaska and New York followed in 1982 (Morgan, Rime, and Strahan, 2004). As part of the Garn-St. Germain Act, federal legislators in 1982 amended the Bank Holding Company Act to allow failed banks and thrifts to be acquired by any bank holding company, regardless of state laws (Kroszner and Strahan, 1999). Many states then entered reciprocal arrangements whereby their banks could be bought by banks in any other state in the arrangement. By 1992, all states but Hawaii had entered an interstate banking agreement with other states. Interstate banking activity increased sharply as a result of deregulation. The percentage of deposits held by subsidiaries of out-of-state MBHCs in the typical state expanded from 2 to 28 percent between 1979 and 1994 (Berger, Kashyap, and Scalise, 1995). ${ }^{84}$

\footnotetext{
${ }^{83}$ The high cost of the MBHC structure is confirmed by the fact that many multibank holding companies converted their bank subsidiaries into branches once branching was allowed (McLaughlin, 1995).

${ }^{84}$ According to Morgan, Rime, and Strahan (2004), in 1975, only 10 percent of bank assets in the typical state were owned by a multistate bank holding company. By 1994, this interstate bank asset ratio had risen to 60 percent.
} 
The transition to interstate banking was completed with passage of the Reigle-Neal Interstate Banking and Branching Efficiency Act of 1994. The Reigle-Neal Act made interstate banking a bank right, not a state right; banks or holding companies could now enter another state without permission (Morgan, Rime, and Strahan, 2004). All the changes were codified at the national level in 1996 when Congress passed the Interstate Banking and Branching Efficiency Act. Banks may now branch not only within states but also across state lines in most cases, and bank holding companies may buy banks anywhere in the U.S. (Black and Strahan, 2002).

\section{Banking Deregulation in the European Union}

Until the late 1970s, banking was heavily regulated in most European Union (EU) member countries, regulation was mostly uncoordinated across countries, and banking markets were severely segmented. Interest rate regulations, capital controls, bank branching restrictions, and branch-level capital requirement were widespread in EU member states. In addition, threats of potential capital controls substantially limited cross-border trade in banking activities (European Commission, 1988). Despite the recognition of freedom of establishment, foreign bank entry restrictions heavily constrained cross-border expansions. The 1980s brought a period of deregulation, gradually lifting most restrictions both within and across EU member states. Finally, starting in the late 1980s and going into the 1990s, the EU started to harmonize bank regulation, and, to some extent, to re-regulate the industry (Danthine, Giavazzi, Vives, and von Thadden, 1999). However, foreign bank penetration remains relatively low, partly indicating relatively high implicit entry barriers raised by national governments.

The Directive on The Abolition of Restrictions on Freedom of Establishment and Freedom to Provide Services for Self-Employed Activities of Banks and Other Financial Institutions, adopted in 1973, applies the national treatment principle, which ensures the equal regulatory and supervisory treatment of all firms operating in one country. Although entry restrictions could not be discriminatory, international competition, through the supply of cross-border services, was severely restricted by regulation on capital flows. Furthermore, there was no coordination of banking supervision, so that banks operating in different member states could be subject to different rules, raising costs of operating internationally (Dermine, 2002).

In the early 1980s, regulatory constraints imposed on banks by national authorities were widespread in the EU. Interest rate regulations were common, with the exception of Germany, the Netherlands, and the U.K. (Romero-Ávila, 2007). Capital controls were in place in Belgium, France, 
Greece, Ireland, Italy, Portugal, and Spain. Banks faced branching restrictions in France, Italy, and Portugal, and there was a branch-level capital requirement in most countries (Romero-Ávila, 2007).

Over the next two decades, the constraints were gradually removed often as a preemptive move ahead of legislation harmonization, aimed at providing a level playing field for all credit institutions operating in different EU member states (Gual, 1999, and Romero-Ávila, 2007). For example, France and Italy lifted interest rate restrictions and liberalized capital flows in 1990, followed by Spain in 1992 (Gual, 1999). Portugal lifted restrictions on branching in 1984, France in 1987, Spain in 1988, and Italy in 1990 (Gual, 1999).

In general, the approach to the removal of regulatory barriers to an integrated EU banking market has been threefold: minimum banking regulation permitting both the establishment of branches and the provision of services across borders throughout the EU; common rules on the supervision and regulation of financial institutions; and entrusting the responsibility for the supervision of banks operating in two or more member states from the host to the home country of the parent bank. The First and Second Banking Directives were the key measures as regards the creation of an integrated European banking market, with a number of other directives in this area playing a supporting role. ${ }^{85}$

The First Banking Directive, adopted in 1977, established the principle of home country control, shifting the responsibility for the supervision of credit institutions operating in two or more member countries from the host to the home country of the parent bank. The directive left national barriers to competition and differences virtually untouched (Danthine, Giavazzi, Vives, and von Thadden, 1999). As the directive provided no specific regulations, the European banking markets remained fragmented for the following reasons: A bank wishing to operate in another country still had to be authorized by the supervisors of that country; A foreign bank remained subject to supervision by the host country, and its range of activities could be constrained by host country laws; In most member states, branches had to be provided with earmarked capital as if they were new banks; Finally, restrictions on capital flows severely impaired the provision of international services (Dermine, 2002).

A first directive on the liberalization of capital movements was adopted in 1960 and a final directive in 1988. The 1988 directive stipulated that freedom of capital movements should exist,

\footnotetext{
${ }^{85}$ Among these, the Solvency Ratio and the Capital Adequacy Directives of 1989 and 1993 (amended between 1992 and 1998), the Consolidated Accounts Directive of 1986, the Branch Establishment Directive of 1989, the Large Exposures Directive of 1992, and the Deposit-Guarantee Schemes Directive of 1994.
} 
in principle, by July 1990. Only Greece, Ireland, Spain, and Portugal could apply derogation provisions until 1993, extended later to 1994 (Benink, 2000). Although the 1988 directive removed restrictions on capital flows, it also authorized member states to take necessary measures in the event of balance of payments problems. Some uncertainty, therefore, persisted concerning the complete and permanent freedom of capital flows (Dermine, 2002).

The Second Banking Directive, adopted in 1989, due to be implemented in 1993 and amended in 1992 and 1995, incorporated the principles of a single banking license, home country control, minimal harmonization of regulations, and mutual recognition of major commercial and investment banking activities (Danthine, Giavazzi, Vives, and von Thadden, 1999, and Dermine, 2002). Under this directive, all credit institutions authorized in a EU member country would be able to establish branches or supply cross-border financial services in other member countries without further authorization, provided that the bank was authorized to provide such services in the home country. Hence, a bank chartered in a EU member country has the right to open a subsidiary in another member country on the same conditions as nationals of the latter country. ${ }^{86}$ The Second Banking Directive implies that national banking markets have become contestable. Hence, either incumbent banks adapt their conduct to prevent foreign entry, or foreign banks might indeed enter a new market.

The Treaty on European Union, adopted in 1992, envisaged a gradual transition to the common currency that concluded with the advent of Economic and Monetary Union in 1999. With irrevocably fixed exchange rates, money and capital markets moved to the euro, while the retail market continued to operate in legacy national currencies until 2002. ${ }^{87}$ The Investment Services Directive of 1993 addressed the cross-border activities of all types of investment firms, including universal banks (Danthine, Giavazzi, Vives, and von Thadden, 1999). Finally, the Financial Services Action Plan, launched in 1999, outlined a series of initiatives to ensure the full integration of banking and capital markets - i.e., a single EU wholesale market-, open and secure retail banking and insurance markets, and development of prudential rules and supervision by 2005 .

\footnotetext{
${ }^{86}$ Note that, whereas the Glass-Steagall Act of 1933 legislated the separation of investment and commercial banking in the U.S., the banking model adopted in the EU was that of universal banking. Accordingly, the Second Banking Directive called for supervisory control of banks' permanent participation in the non-financial sector, while leaving control over financial conglomerates (the ownership structure of banks) to national regulators.

${ }^{87}$ As Gual (1999) notes, the introduction of the common currency did not necessarily mean in practice that a single market for financial services was created. First, in spite of advances in financial services provision with no need for physical proximity, there are still high "transport costs" in retail banking, and this means that entry into foreign markets must be based largely on the opening (or acquisition) of a branch network. Second, even though horizontal differentiation is hard to achieve in banking, this is not incompatible with preferences for domestic service providers, based on perceived quality. These preferences may lead to foreign competitors having only a very small share of local markets.
} 
The harmonization of banking regulation in the EU should have been accomplished by 1993 . However, it can be argued that the harmonization, while substantial on paper, has not been as effective in practice (Danthine, Giavazzi, Vives, and von Thadden, 1999). First, regulatory changes need time to feed through the legal systems of each member state. For example, the Second Banking Directive was implemented a year past the deadline for national implementation in the United Kingdom, Luxemburg, Belgium, and Spain. Second, despite the regulatory changes, a number of important impediments to cross-border activity - such as exceptions to the single market principle or host country control related to consumer protection or "general good" — remain. Cerasi, Chizzolini, and Ivaldi (1998) conclude that it is hard to identify the origin of changes in industry structure in the set of directives, even considering the actual implementation date in each state. Non-regulatory barriers, such as taxation of investment income that discriminates along national boundaries, might impede the cross-border activity of financial institutions as well. Legal differences between EU member states, in particular the lack of some form of common corporate law, also contribute to market segmentation. ${ }^{88}$

\section{The Effects of Banking Deregulation in the EU}

In anticipation of the Second Banking Directive, which stipulated removal of barriers to entry into new markets, banks consolidated locally in many EU member countries. Despite the resultant high bank concentration, both the costs and prices of banking services fell. Although bank market integration and competition in the EU lagged behind the U.S., motivating the assumed asymmetry across countries in our exercise, the improvements in banking appear to have lowered concentration in non-financial industries and boosted aggregate output growth, suggesting a reversal of effects as the EU catches up to the U.S. over time.

As we noted above, until the early 1990s, banks were still protected from competition through formal and informal barriers to market entry, collusive arrangements, and regulation. ${ }^{89}$ However, at least until the early 1990s, this lack of competition was not associated with industry concentration at the national level, and it indicates rather fragmented national markets (Danthine, Giavazzi, Vives, and von Thadden, 1999). The surge in international consolidation in the late 1990s resulted in the emergence of large banks, mostly competing in wholesale markets and providing banking services to large firms (Dermine, 2002). However, the retail market servicing small and medium enterprises,

\footnotetext{
${ }^{88}$ We do not discuss post-2000 regulations such as the Regulation on the European Company Statute of 2001 and the EU Takeover Directive of 2004 because the focus of our paper is on the 1970s-2000 period.

${ }^{89}$ See also Gual and Neven (1993) and Vives (1991).
} 
which employ more than 50 percent of the labor force, has remained mostly domestic and local. In fact, since the mid 1990s, domestic consolidation in the EU has considerably increased the level of concentration (European Central Bank, 2005). In several member countries, domestic incumbents have preserved their market share, and antitrust measures exceed the oligopoly threshold (Dermine, 2002). In contrast to the U.S., where the percentage of bank assets owned by a multistate bank holding company in the typical state surged following deregulation, foreign bank penetration in the EU remains relatively low, with the share of assets owned by foreign banks averaging 15 percent. The low foreign bank shares in EU member countries may primarily result from net comparative disadvantages for foreign banks and relatively high implicit government entry barriers (Berger, 2007). Indeed, cross-border mergers among commercial banks - which should be preferred to domestic consolidation because they exploit economies of scale without posing any threat to competition - run against a deeply ingrained and widespread desire to foster national champions and are often frowned upon, discouraged, or even prevented (Danthine, Giavazzi, Vives, and von Thadden, 1999).

The intermediation margin on the retail market has declined in many member states (Danthine, Giavazzi, Vives, and von Thadden, 1999 and Dermine, 2002). For example, Angelini and Cetorelli (2003) find that competitive conditions in the Italian banking industry improved substantially with the implementation of the Second Banking Directive, as indicated by the decline in estimated markups. They also find no evidence that consolidated banks gained market power; at the same time, these banks exhibited lower costs than the industry average. Cetorelli (2004) finds that enhanced bank competition following the implementation of the Second Banking Directive lowered concentration in non-financial industries in the EU. ${ }^{90}$

An important concern is whether consolidation may have lead to a reduction in small business lending. Some empirical evidence indicates that there might be hardly any negative effects. For example, Bonaccorsi di Patti and Gobbi (2003) show that bank consolidation had no negative impact on outstanding credit in Italy and did not raise the investment-cash flow sensitivity of privately held firms. They find that borrowers of acquired banks tended to experience an expansion of credit at least in the short run. Bank consolidation did not appear to have adverse effects even for smaller firms, those that depend on fewer banks and those that are riskier. However, no expansionary effect of acquisitions is found for these borrowers, suggesting that banks transferred

\footnotetext{
${ }^{90}$ However, Cetorelli cautions against inferring the long-run effects of deregulation on the market structure of EU non-financial industries given the short span of the data set.
} 
part of the efficiency gains on their safer and larger corporate customers.

The Second Banking Directive, endorsing universal banking, encouraged banks to engage in non-commercial banking activities such as investment banking, asset management and insurance, thereby fostering cross-sector consolidation in the financial sector. As a result, the ratio of bank assets to GDP doubled in several member countries (Dermine, 2002). Similarly to the U.S., where states enjoyed faster income growth following banking deregulation (Jayaratne and Strahan, 1996), Romero-Ávila (2007) finds that banking deregulation raised output growth in the EU, mainly through improvements in the efficiency of financial intermediation, possibly furthered by competition pressures.

\section{B Benchmark Model: The Steady State}

Without normalizing $Z=Z^{*}$ and $L=L^{*}$ to 1 , steady-state levels of selected variables are below:

$$
\begin{aligned}
N & =\frac{(1-\delta) \beta\left(1-\frac{1}{H}\right)}{\left(\frac{\theta}{\alpha}-1\right)[1-\beta(1-\delta)]+\delta \beta\left(1-\frac{1}{H}\right)} Z L \\
w & =\left\{\frac{1}{\mu}\left[N\left(1+\tau^{1-\theta}\right)\right]^{1 /(\theta-1)}\right\}^{\alpha} Z \\
q & =\frac{1}{1-\delta} \frac{w}{Z} \\
\rho_{N} & =\frac{w}{Z} \\
\rho_{T} & =\left(\frac{w}{Z}\right)^{(\alpha-1) / \alpha}, \\
\rho_{D} & =\mu\left(\frac{w}{Z}\right)^{1 / \alpha}, \\
\rho_{X} & =\tau \rho_{D}, \\
d & =\left[\frac{1-\beta(1-\delta)}{(1-\delta) \beta\left(1-\frac{1}{H}\right)}\right] \frac{w}{Z}, \\
B & =\frac{w}{Z} \frac{\delta}{1-\delta} N, \\
C & =\frac{\theta}{\alpha}\left\{\left[\mu\left(\frac{w}{Z}\right)^{1 / \alpha}\right]^{1-\theta}\left(1+\tau^{1-\theta}\right)\right\}^{-1} d .
\end{aligned}
$$




\section{Home Bias in Consumption}

Our alternative model setup does not feature non-traded goods but introduces home bias in consumption. We define the consumption basket as

$$
C_{t}=\left[\alpha^{1 / \theta}\left(C_{H, t}\right)^{(\theta-1) / \theta}+(1-\alpha)^{1 / \theta}\left(C_{F, t}\right)^{(\theta-1) / \theta}\right]^{\theta /(\theta-1)},
$$

where $C_{H, t}$ is the sub-basket of traded goods produced at home, $C_{F, t}$ is the sub-basket of traded goods produced in the foreign country, and $\theta$ is the elasticity of substitution between these subbaskets. The positive parameter $\alpha$ is the weight of the home sub-basket in the overall home consumption basket (and the weight of the foreign sub-basket in the foreign consumption basket), and the assumption $\alpha>1 / 2$ captures home bias in consumption.

The sub-baskets of home and foreign goods are defined as

$$
C_{H, t}=\left(\int_{\omega \in \Omega} c_{H, t}(\omega)^{(\theta-1) / \theta} d \omega\right)^{\theta /(\theta-1)} \text { and } C_{F, t}=\left(\int_{\omega^{*} \in \Omega} c_{F, t}\left(\omega^{*}\right)^{(\theta-1) / \theta} d \omega^{*}\right)^{\theta /(\theta-1)},
$$

where $\theta>1$ is the symmetric elasticity of substitution across individual goods. ${ }^{91}$ At any given time $t$, only a subset of home goods $\Omega_{t} \subset \Omega$ and foreign goods $\Omega_{t}^{*} \subset \Omega$ is available at home and abroad. Let $P_{D, t}$ and $P_{F, t}$ denote the home currency price indexes associated to the home and foreign subbaskets. We assume that export prices are denominated in the currency of the export market. The consumption-based price index for the home economy is then $P_{t}=\left[\alpha\left(P_{D, t}\right)^{1-\theta}+(1-\alpha)\left(P_{F, t}\right)^{1-\theta}\right]^{1 /(1-\theta)}$. Let $p_{D, t}(\omega)$ and $p_{F, t}\left(\omega^{*}\right)$ denote the home currency prices of home and foreign goods, respectively. Then,

$$
P_{D, t}=\left(\int_{\omega \in \Omega_{t}} p_{D, t}(\omega)^{1-\theta} d \omega\right)^{1 /(1-\theta)} \text { and } P_{F, t}=\left(\int_{\omega^{*} \in \Omega_{t}^{*}} p_{F, t}\left(\omega^{*}\right)^{1-\theta} d \omega^{*}\right)^{1 /(1-\theta)} \text {. }
$$

The household's demand for each individual home good $\omega$ is $c_{D, t}(\omega)=\alpha\left(p_{D, t}(\omega) / P_{t}\right)^{-\theta} C_{t}$ and for each individual foreign good $\omega^{*}$ is $c_{F, t}\left(\omega^{*}\right)=(1-\alpha)\left(p_{F, t}\left(\omega^{*}\right) / P_{t}\right)^{-\theta} C_{t}$. Consumer preferences and price indexes in the foreign economy are similar, except for the assumption that preferences are biased in favor of the sub-basket of goods produced in the foreign country. Home bias implies that

\footnotetext{
${ }^{91}$ To avoid introducing a difference relative to the model with non-traded goods other than replacing the latter with the assumption of home bias, we assume that the elasticity of substitution between home and foreign traded sub-baskets is the same as the elasticity of substitution between individual goods within those sub-baskets. (The model with non-traded goods features equal substitutability of traded goods within and across countries.)
} 
PPP does not hold even when the law of one price holds (i.e., even if trade costs are set to zero).

Firms set prices as constant markups $\mu=\theta /(\theta-1)$ over marginal cost. Home firm prices, in real terms relative to the price index in the destination market, are then given by $\rho_{D, t}(\omega)=$ $p_{D, t}(\omega) / P_{t}=\mu w_{t} / Z_{t}$ and $\rho_{H, t}=p_{X, t}(\omega) / P_{t}^{*}=\tau Q_{t}^{-1} \mu w_{t} / Z_{t}$. In the case of a home firm, total profits in period $t$ are given by $d_{t}(\omega)=d_{D, t}(\omega)+d_{X, t}(\omega)$, where profits from domestic sales are $d_{D, t}(\omega)=\alpha / \theta\left(\rho_{D, t}\right)^{1-\theta} C_{t}$, and profits from export sales are $d_{X, t}(\omega)=(1-\alpha) / \theta Q_{t}\left(\rho_{X, t}\right)^{1-\theta} C_{t}^{*}$. Since all firms are identical in equilibrium, we drop the index $\omega$ below. Foreign firms behave in a similar way. ${ }^{92}$ Labor market equilibrium requires: $L=(\theta-1) d_{t} N_{t} / w_{t}+N_{E, t} / Z_{t}$.

The model with traded goods only and home bias in consumption can be summarized by deleting the overall price index equation from Table 1 and replacing the tradable price index, the goods pricing equations, and the firm profit equation with the following equations (only the equations pertaining to the home variables are shown):

Overall price index:

$$
\begin{array}{lc}
\text { Overall price index: } & \alpha N_{t}\left(\rho_{D, t}\right)^{1-\theta}+(1-\alpha) N_{t}^{*}\left(\rho_{X, t}^{*}\right)^{1-\theta}=1, \\
\text { Goods pricing, home market: } & \rho_{D, t}=\mu \frac{w_{t}}{Z_{t}}, \\
\text { Goods pricing, foreign market: } & \rho_{X, t}=\tau Q_{t}^{-1} \mu \frac{w_{t}}{Z_{t}}, \\
\text { Firm profit: } & d_{t}=\frac{\alpha}{\theta}\left(\rho_{D, t}\right)^{1-\theta} C_{t}+\frac{1-\alpha}{\theta} Q_{t}\left(\rho_{X, t}\right)^{1-\theta} C_{t}^{*} .
\end{array}
$$$$
\text { Goods pricing, foreign market: } \quad \rho_{X, t}=\tau Q_{t}^{-1} \mu \frac{w_{t}}{Z_{t}} \text {, }
$$

Note that, in the economy with only traded goods and home bias in consumption, the home (foreign) consumption-based price index can be decomposed as $P_{t}=\left(\alpha N_{t}+(1-\alpha) N_{t}^{*}\right)^{1 /(1-\theta)} \tilde{P}_{t}$ $\left(P_{t}^{*}=\left(\alpha N_{t}^{*}+(1-\alpha) N_{t}\right)^{1 /(1-\theta)} \tilde{P}_{t}^{*}\right)$, where $\tilde{P}_{t}\left(\tilde{P}_{t}^{*}\right)$ is the average nominal price for all varieties sold in home (foreign). As we discussed in the main text, the data-consistent real exchange rate $\tilde{Q}_{t} \equiv \varepsilon_{t} \tilde{P}_{t}^{*} / P_{t}$ no longer coincides with the welfare-consistent real exchange rate $Q_{t}$.

When we consider a model with a discrete set of producers in each country, the baskets of home and foreign goods are defined as

$$
C_{D, t}=\left(\sum_{\omega \in \Omega} c_{D, t}(\omega)^{(\theta-1) / \theta} d \omega\right)^{\theta /(\theta-1)} \quad \text { and } \quad C_{F, t}=\left(\sum_{\omega^{*} \in \Omega} c_{F, t}\left(\omega^{*}\right)^{(\theta-1) / \theta} d \omega^{*}\right)^{\theta /(\theta-1)}
$$

and the corresponding price indexes for home and foreign baskets are

$$
P_{D, t}=\left(\sum_{\omega \in \Omega_{t}} p_{D, t}(\omega)^{1-\theta} d \omega\right)^{1 /(1-\theta)} \quad \text { and } \quad P_{F, t}=\left(\sum_{\omega^{*} \in \Omega_{t}} p_{F, t}\left(\omega^{*}\right)^{1-\theta} d \omega^{*}\right)^{1 /(1-\theta)}
$$

Analogously to the model with non-traded goods, each producer no longer ignores the effects

\footnotetext{
${ }^{92}$ Note though that a foreign firm earns export profits $d_{X, t}^{*}=(1-\alpha) / \theta Q_{t}^{-1}\left(\rho_{X, t}^{*}\right)^{1-\theta} C_{t}$.
} 
of its nominal domestic price, $p_{D, t}(\omega)$, on the home overall price index, $P_{t}$, and the effect of its nominal export price, $p_{X, t}(\omega)$, on the foreign overall price index, $P_{t}^{*}$. The perceived home demand elasticities is then $\theta_{D, t}(\omega)=\theta\left(1-\left(p_{D, t}(\omega) / P_{t}\right)^{1-\theta}\right)$, and the foreign demand elasticity is $\theta_{X, t}(\omega)=\theta\left(1-\left(p_{X, t}(\omega) / P_{t}^{*}\right)^{1-\theta}\right)$. The implied markups in the domestic and foreign markets are, respectively, $\mu_{D, t}(\omega)=\theta_{D, t}(\omega) /\left(\theta_{D, t}(\omega)-1\right)$ and $\mu_{X, t}(\omega)=\theta_{X, t}(\omega) /\left(\theta_{X, t}(\omega)-1\right)$. Prices, in real terms relative to the price index in the destination market, are then given by $\rho_{D, t}(\omega)=p_{D, t}(\omega) / P_{t}=$ $\mu_{D, t}(\omega) w_{t} / Z_{t}$ and $\rho_{X, t}(\omega)=p_{X, t}(\omega) / P_{t}^{*}=Q_{t}^{-1} \tau \mu_{X, t}(\omega) w_{t} / Z_{t}$. Similar price equations hold for foreign firms. Dropping the index $\omega$ because of symmetry, a home firms total profit is $d_{t}=$ $d_{D, t}+d_{X, t}$, with $d_{D, t}=\alpha\left(\rho_{D, t}\right)^{1-\theta} C_{t} / \theta_{D, t}$ and $d_{X, t}=(1-\alpha) Q_{t}\left(\rho_{X, t}\right)^{1-\theta} C_{t}^{*} / \theta_{X, t}$. Foreign firms behave in a similar way. In this economy, the bank internalizes the effect of entry on firm profits through the effect of entry on the nominal domestic price, $p_{D, t}$, and then on the home general price index, $P_{t}$, and the effect of entry on the nominal export price, $p_{X, t}$, and then on the foreign general price index, $P_{t}^{*}$. Labor market equilibrium (with elastic labor supply) requires:

$$
L_{t}=\left(\frac{\theta_{D, t}-1}{w_{t}} d_{D, t}+\frac{\theta_{X, t}-1}{w_{t}} d_{X, t}\right) N_{t}+\frac{N_{E, t}}{Z_{t}} .
$$

The following equation replace equations in Table 2 (after deleting the equation for the overall price index):

$$
\begin{array}{lc}
\text { Overall price index (home): } & \alpha N_{t}\left(\rho_{D, t}\right)^{1-\theta}+(1-\alpha) N_{t}^{*}\left(\rho_{X, t}^{*}\right)^{1-\theta}=1, \\
\text { Goods pricing, home market: } & \rho_{D, t}=\left(\frac{\theta_{D, t}}{\theta_{D, t}-1}\right) \frac{w_{t}}{Z_{t}}, \\
\text { Goods pricing, foreign market: } & \rho_{X, t}=\tau Q_{t}^{-1}\left(\frac{\theta_{X, t}}{\theta_{X, t}-1}\right) \frac{w_{t}}{Z_{t}}, \\
\text { Firm profit, home market: } & d_{D, t}=\frac{\alpha}{\theta_{D, t}}\left(\rho_{D, t}\right)^{1-\theta} C_{t}, \\
\text { Firm profit, foreign market: } & d_{X, t}=\frac{1-\alpha}{\theta_{X, t}} Q_{t}\left(\rho_{X, t}\right)^{1-\theta} C_{t}^{*}, \\
\text { Labor market clearing: } & L_{t}=\left(\frac{\theta_{D, t}-1}{w_{t}} d_{D, t}+\frac{\theta_{X, t}-1}{w_{t}} d_{X, t}\right) N_{t}+\frac{N_{E, t}}{Z_{t}} .
\end{array}
$$

Figures A.1-A.6 repeat the experiments of figures 1-6, showing the qualitative similarity of key results between the model with non-traded goods and the model with home bias. ${ }^{93}$

\footnotetext{
${ }^{93}$ Note, however, the possibility of depreciation of the welfare-consistent real exchange rate, even if the dataconsistent one appreciates, for the reasons we discussed in the main text.
} 


\section{International Deposits}

The budget constraint of the representative home household, in units of the home consumption basket, is now

$B_{t+1}+Q_{t} B_{*, t+1}+\frac{\eta}{2} Q_{t}\left(B_{*, t+1}\right)^{2}+v_{t} x_{t+1}+C_{t}=\left(1+r_{t}\right) B_{t}+Q_{t}\left(1+r_{t}^{*}\right) B_{*, t}+\left(\pi_{t}+v_{t}\right) x_{t}+T_{t}^{F}+w_{t} L$

where $B_{t}$ denotes holdings of home deposits, $B_{*, t}$ denotes holdings of foreign deposits, $\eta Q_{t}\left(B_{*, t+1}\right)^{2} / 2$ is the cost of adjusting holdings of foreign deposits, $T_{t}^{F}$ is the fee rebate, taken as given by the household, and equal to $\eta Q_{t}\left(B_{*, t+1}\right)^{2} / 2$ in equilibrium. For simplicity, we assume that the scale parameter $\eta>0$ is identical across costs of adjusting holdings of home and foreign deposits. Also, there is no cost of adjusting equity holdings, since our assumption of no international trade in bank shares makes such costs unnecessary for our purposes. The representative foreign household faces a similar constraint in units of foreign consumption.

Home and foreign households maximize the respective intertemporal utility functions subject to the respective constraints. The first-order conditions for the choice of share holdings in the mutual fund of domestic banks and for holdings of domestic deposits are unchanged relative to the case of financial autarky. A new Euler equation for foreign deposit holdings must be added to Table 1, and a new deposit market clearing condition and expression for bank profits replace equations in that table. Since trade is no longer balanced with international deposits, we must explicitly impose labor market clearing conditions in both countries. Finally, to close the model, we must add the net foreign asset equation. Budget constraints at home and abroad (after imposing equity market clearing, labor market clearing, and fee rebates) imply:

$$
\begin{aligned}
B_{t+1}+Q_{t} B_{*, t+1}+C_{t} & =\left(1+r_{t}\right) B_{t}+Q_{t}\left(1+r_{t}^{*}\right) B_{*, t}+\pi_{t}+w_{t} L, \\
\frac{B_{t+1}^{*}}{Q_{t}}+B_{*, t+1}^{*}+C_{t}^{*} & =\left(1+r_{t}\right) \frac{B_{t}^{*}}{Q_{t}}+\left(1+r_{t}^{*}\right) B_{*, t}^{*}+\pi_{t}^{*}+w_{t}^{*} L^{*},
\end{aligned}
$$

Multiplying the foreign aggregate budget constraint by $Q_{t}$, subtracting from the home aggregate budget constraint, and using $B_{t+1}=\left(w_{t} / Z_{t}\right) N_{E, t}-B_{t+1}^{*}, B_{*, t+1}^{*}=\left(w_{t}^{*} / Z_{t}^{*}\right) N_{E, t}^{*}-B_{*, t+1}, \pi_{t}=$ $d_{t} N_{t}-\left(1+r_{t}\right)\left(w_{t} / Z_{t}\right) N_{E, t}$, and $\pi_{t}^{*}=d_{t}^{*} N_{t}^{*}-\left(1+r_{t}^{*}\right)\left(w_{t}^{*} / Z_{t}^{*}\right) N_{E, t}^{*}$ yields the law of motion for 
home net foreign assets:

$$
\begin{aligned}
Q_{t} B_{*, t+1}-B_{t+1}^{*}= & Q_{t}\left(1+r_{t}^{*}\right) B_{*, t}-\left(1+r_{t}\right) B_{t}^{*}+\frac{1}{2}\left(w_{t} L-Q_{t} w_{t}^{*} L^{*}\right)+\frac{1}{2}\left(d_{t} N_{t}-Q_{t} d_{t}^{*} N_{t}^{*}\right) \\
& -\frac{1}{2}\left(C_{t}-Q_{t} C_{t}^{*}\right)-\frac{1}{2}\left(\frac{w_{t}}{Z_{t}} N_{E, t}-Q_{t} \frac{w_{t}^{*}}{Z_{t}^{*}} N_{E, t}^{*}\right) .
\end{aligned}
$$

This is the analog to the law of motion for net foreign assets in Ghironi and Melitz (2005) (note that $B_{t+1}^{*}=-B_{t+1}$ there). It states that net foreign assets (home holdings of foreign deposits minus foreign holdings of home deposits) entering $t+1$ are determined by net interest income on net foreign assets entering $t$, and the differentials in aggregate labor and dividend incomes (GDP's), consumptions, and investments (in new firms). Thus, we define net foreign assets as:

$$
A_{t+1} \equiv Q_{t} B_{*, t+1}-B_{t+1}^{*}
$$

the current account as:

$$
C A_{t} \equiv Q_{t}\left(B_{*, t+1}-B_{*, t}\right)-\left(B_{t+1}^{*}-B_{t}^{*}\right)
$$

and the trade balance as:

$$
T B_{t} \equiv \frac{1}{2}\left(w_{t}-Q_{t} w_{t}^{*}\right)+\frac{1}{2}\left(d_{t} N_{t}-Q_{t} d_{t}^{*} N_{t}^{*}\right)-\frac{1}{2}\left(C_{t}-Q_{t} C_{t}^{*}\right)-\frac{1}{2}\left(\frac{w_{t}}{Z_{t}} N_{E, t}-Q_{t} \frac{w_{t}^{*}}{Z_{t}^{*}} N_{E, t}^{*}\right) .
$$

When variables are zero in steady state (net foreign assets, current account, trade balance), we normalize by the symmetric steady-state level of consumption in log-linearizing the model.

A summary of new (or changed) equations (for the home country) relative to Table 1 is below: 
Bank profits:

Euler equations for foreign deposits:

Deposit market clearing:

Net foreign assets:

Current account:

Labor market clearing (with non-traded goods):

Labor market clearing (with home bias):

$$
\begin{gathered}
\pi_{t}=d_{t} N_{t}-\left(1+r_{t}\right)\left(B_{t}+B_{t}^{*}\right), \\
1+\eta B_{*, t}=\beta\left(1+r_{t+1}^{*}\right) E_{t}\left[\left(\frac{Q_{t+1}}{Q_{t}}\right)\left(\frac{C_{t+1}}{C_{t}}\right)^{-\gamma}\right], \\
B_{t}+B_{t}^{*}=\frac{w_{t}}{Z_{t}} N_{E, t}, \\
Q_{t} B_{*, t+1}-B_{t+1}^{*} \\
=Q_{t}\left(1+r_{t}^{*}\right) B_{*, t}-\left(1+r_{t}\right) B_{t}^{*} \\
+\frac{1}{2}\left(w_{t} L-Q_{t} w_{t}^{*} L^{*}\right)+\frac{1}{2}\left(d_{t} N_{t}-Q_{t} d_{t}^{*} N_{t}^{*}\right) \\
-\frac{1}{2}\left(C_{t}-Q_{t} C_{t}^{*}\right)-\frac{1}{2}\left(\frac{w_{t}}{Z_{t}} N_{E, t}-Q_{t} \frac{w_{t}^{*}}{Z_{t}^{*}} N_{E, t}^{*}\right), \\
C A_{t}=Q_{t}\left(B_{*, t+1}-B_{*, t}\right)-\left(B_{t+1}^{*}-B_{t}^{*}\right), \\
L=\frac{\theta-1}{w_{t}} d_{t} N_{t}+\frac{N_{E, t}}{Z_{t}}+\frac{1-\alpha}{Z_{t}} \frac{C_{t}}{\rho_{N, t}} \\
L=\frac{\theta-1}{w_{t}} d_{t} N_{t}+\frac{N_{E, t}}{Z_{t}}
\end{gathered}
$$

The presence of the term that depends on the stock of deposits in the left-hand side of the equations for deposit holdings abroad is crucial for determinacy of the steady state and stationarity of responses to non-permanent shocks. To see that fees on deposits abroad are enough to pin down a unique steady state that coincides with that under financial autarky, proceed as follows. Steadystate Euler equations for domestic deposits in each country imply $\beta(1+r)=1$ and $\beta\left(1+r^{*}\right)=1$. Hence, steady-state Euler equations for deposits abroad imply the unique steady-state holdings $B_{*}=0$ and $B^{*}=0$ (as long as $\eta>0$ ). Deposit market clearing conditions then imply $B=w N_{E} / Z$ and $B_{*}^{*}=w^{*} N_{E}^{*} / Z^{*}$. The steady state will then be symmetric across countries and coincide with that under financial autarky under the assumptions $L=L^{*}, Z=Z^{*}$, and $H=H^{*}$.

\section{E Countercyclical Firm Markups}

\section{Internalization of Profit Destruction Externality}

The first order condition with respect to $N_{t+1}(h)$ gives the Euler equation for the shadow value of an additional producing firm to bank $h, q_{t}(h)$, and involves a term capturing the internalization of the profit destruction externality:

$$
q_{t}(h)=\beta E_{t}\left\{\left(\frac{C_{t+1}}{C_{t}}\right)^{-1}\left[\begin{array}{c}
d_{D, t+1}+d_{X, t+1}+N_{t+1}(h)\left(\frac{\partial d_{D, t+1}}{\partial N_{t+1}} \frac{\partial N_{t+1}}{\partial N_{t+1}(h)}+\frac{\partial d_{X, t+1}}{\partial N_{t+1}} \frac{\partial N_{t+1}}{\partial N_{t+1}(h)}\right) \\
+(1-\delta) q_{t+1}(h)
\end{array}\right]\right\} .
$$


Internalization of the effect of entry on firm profits through the effect on the nominal domestic price, $p_{D, t}$, and then on the home tradable price index $P_{T, t}$ (or the overall home price index, $P_{t}$, in the model with home bias), and the effect of entry on the nominal export price, $p_{X, t}$, and then on the foreign tradable price index $P_{T, t}^{*}$ (or the overall foreign price index, $P_{t}^{*}$, in the model with home bias), works as follows. Rearrange the home tradable price index (or the overall home price index) as $\left(\rho_{D, t}\right)^{1-\theta}=\left[1-N_{t}^{*}\left(\rho_{X, t}^{*}\right)^{1-\theta}\right] / N_{t}$, then the elasticity of demand is $\theta_{D, t}=\theta\left\{N_{t}-\left[1-N_{t}^{*}\left(\rho_{X, t}^{*}\right)^{1-\theta}\right]\right\} / N_{t}$, Firm profits in the home market are $d_{D, t}=$ $\left[1-N_{t}^{*}\left(\rho_{X, t}^{*}\right)^{1-\theta}\right] C_{t} /\left\{\theta\left[N_{t}-\left(1-N_{t}^{*}\left(\rho_{X, t}^{*}\right)^{1-\theta}\right)\right]\right\}$, and, under symmetry,

$$
\begin{aligned}
\frac{\partial d_{D, t+1}}{\partial N_{t+1}} \frac{\partial N_{t+1}}{\partial N(h)_{t+1}} N(h)_{t+1}+d_{D, t+1} & =\left\{1-\frac{1}{H} \frac{N_{t+1}}{\left(N_{t+1}-\left(1-N_{t+1}^{*}\left(\rho_{X, t}^{*}\right)^{1-\theta}\right)\right)}\right\} d_{D, t+1} \\
& =\left[1-\frac{1}{H} \frac{1}{1-\left(\rho_{D, t+1}\right)^{1-\theta}}\right] d_{D, t+1} \\
& =\left(1-\frac{1}{H} \frac{\theta}{\theta_{D, t+1}}\right) d_{D, t+1} .
\end{aligned}
$$

Similarly,

$$
\frac{\partial d_{X, t+1}}{\partial N_{t+1}} \frac{\partial N_{t+1}}{\partial N(h)_{t+1}} N(h)_{t+1}+d_{X, t+1}=\left(1-\frac{1}{H} \frac{\theta}{\theta_{X, t+1}}\right) d_{X, t+1} .
$$

Substituting these results into the Euler equation above yields the Euler equation in the main text.

\section{References}

[1] Anderson, James, and Eric van Wincoop. 2004. "Trade Costs," Journal of Economic Literature 42(3): 691-751.

[2] Angelini, Paolo, and Nicola Cetorelli. 2003. "The Effects of Regulatory Reform on Competition in the Banking Industry," Journal of Money, Credit and Banking 35 (4): 663-684.

[3] Baxter, Marianne. 1995. "International Trade and Business Cycles," Handbook of International Economics, vol. 3, ed. Grossman, G. M., and K. Rogoff, 1801-1864. Amsterdam: Elsevier.

[4] Baxter, Marianne, and Dorsey D. Farr. 2005. "Variable Factor Utilization and International Business Cycles," Journal of International Economics 65(2): 335-347.

[5] Benink, Harald. 2000. "Europe's Single Banking 2000. "Europe's Single Banking Market," Journal of Financial Services Research 17: 319-322. 
[6] Berger, Allen. 2007. "Obstacles to a Global Banking System: 'Old Europe' versus 'New Europe'," Journal of Banking \& Finance 31(7): 1955-1973.

[7] Berger, Allen N., Rebecca S. Demsetz, and Philip E. Strahan. 1999. "The Consolidation of the Financial Services Industry: Causes, Consequences, and Implications for the Future," Journal of Banking and Finance 23(2-4): 135-194.

[8] Berger, Allen, Anil K. Kashyap, and Joseph M. Scalise. 1995. "The Transformation of the U.S. Banking Industry: What a Long, Strange Trips It's Been," Brookings Papers on Economic Activity 26: 55-218.

[9] Bergin, Paul R., and Giancarlo Corsetti. 2008. "The Extensive Margin and Monetary Policy," Journal of Monetary Economics 55 (7): 1222-1237.

[10] Bernanke, Ben S. 2005. "The Global Saving Glut and the U.S. Current Account Deficit," Sandridge Lecture, Virginia Association of Economics, Richmond, Virginia.

[11] Bernard, Andrew B., J. Eaton, Jonathan, Bradford Jensen, and Samuel Kortum. 2003. "Plants and Productivity in International Trade," American Economic Review 93 (4): 1268-1290.

[12] Bertrand, Marianne, Antoinette Schoar, and David Thesmar. 2007. "Banking Deregulation and Industry Structure: Evidence from the French Banking Reforms of 1985," Journal of Finance 62(2): 597-628.

[13] Bilbiie, Florin O., Fabio Ghironi, and Marc J. Melitz. 2007. "Endogenous Entry, Product Variety, and Business Cycles," NBER WP 13646.

[14] Bilbiie, Florin O., Fabio Ghironi, and Marc J. Melitz. 2008. "Monetary Policy and Business Cycles with Endogenous Entry and Product Variety," in NBER Macroeconomics Annual 2007, ed. Acemoglu, D., K. S. Rogoff, and M. Woodford, 299-353. Chicago, IL: University of Chicago Press.

[15] Black, Sandra E., and Philip. E. Strahan. 2002. "Entrepreneurship and Bank Credit Availability," Journal of Finance 57(6): 2801-2833.

[16] Bonaccorsi di Patti, Emilia, and Giorgio Gobbi. 2003. "The Effects of Bank Mergers on Credit Availability: Evidence from Corporate Data," Banca d'Italia Working Paper 479.

[17] Caballero, Ricardo J., Emmanuel Fahri, and Pierre-Olivier Gourinchas. 2008. "An Equilibrium Model of 'Global Imbalances' and Low Interest Rates," American Economic Review 98(1): 358-393.

[18] Cerasi, Vittoria, Barbara Chizzolini, and Marc Ivaldi. 1998. "Sunk Costs and Competitiveness of European Banks after Deregulation," LSE-FMG Discussion Paper 290.

[19] Cestone, Giacinta, and Lucy White. 2003. "Anticompetitive Financial Contracting: The Design of Financial Claims," Journal of Finance 58 (5): 2109-2142.

[20] Cetorelli, Nicola. 2004. "The Real Effects of Bank Competition, " Journal of Money, Credit and Banking 36(3): 543-558.

[21] Cetorelli, Nicola, and Philip E. Strahan. 2006. "Finance as a Barrier to Entry: Bank Competition and Industry Structure in Local U.S. Markets," Journal of Finance 61(1): 437-461. 
[22] Cogley, Timothy, and Thomas J. Sargent. 2005. "Drifts and Volatilities: Monetary Policies and Outcomes in the Post WWII U.S.," Review of Economic Dynamics 8(2): 262-302.

[23] Correa, Ricardo, and Gustavo A. Suarez. 2007. "Firm Volatility and Banks: Evidence from U.S. Banking Deregulation," manuscript, Board of Governors of the Federal Reserve System.

[24] Corsetti, Giancarlo, Philippe Martin, and Paolo Pesenti. 2007. "Productivity, Terms of Trade, and the 'Home Market Effect'," Journal of International Economics 73(1): 99-127.

[25] Corsetti, Giancarlo, Philippe Martin, and Paolo Pesenti. 2008. "Varieties and the Transfer Problem: The Extensive Margin of Current Account Adjustment," NBER WP 13795.

[26] Danthine, Jean-Pierre, Francesco Giavazzi, Xavier Vives, and Ernest-Ludwig von Thadden. 1999. "The Future of European Banking," Monitoring European Integration 9, CEPR.

[27] D'Aspremont, Claude, Rodolphe D. S. Ferreira, and Louis-Andre Gerard-Varet. 1996. "On the Dixit-Stiglitz Model of Monopolistic Competition," American Economic Review 86(3): 623-629.

[28] Davis, Steven J., John Haltiwanger, Ron Jarmin, and Javier Miranda. 2006. "Volatility and Dispersion in Business Growth Rates: Publicly Traded versus Privately Held Firms," NBER WP 12354.

[29] De Bandt, Olivier, and E. Philip Davis. 2000. "Competition, Contestability and Market Structure in European Banking Sectors on the Eve of EMU," Journal of Banking and Finance 24(6): 1045-1066.

[30] Demyanyk, Yuliya, Charlotte Østergaard, and Bent E. Sørensen. 2007. "U.S. Banking Deregulation, Small Businesses, and Interstate Insurance of Personal Income," Journal of Finance 62: $2763-2801$.

[31] Dermine, Jean. 2002. "European Banking: Past, Present, and Future," manuscript, HEC Lausanne.

[32] Devereux, Marcel B., and Alan Sutherland. 2010. "Country Portfolios in Open Economy Macro Models," Journal of the European Economic Association, forthcoming.

[33] Dick, Astrid A. 2006. "Nationwide Branching and Its Impact on Market Structure, Quality, and Bank Performance," Journal of Business 79(2): 567-592.

[34] Elkhoury, Marwan, and Tommaso Mancini Griffoli. 2006. "Monetary Policy with Firm Entry," manuscript, Graduate Institute of International Studies, Geneva, and Swiss National Bank.

[35] Erceg, Christopher J., Luca Guerrieri, and Christopher J. Gust. 2005. "Expansionary Fiscal Shocks and the Trade Deficit," International Finance 8(3): 363-397.

[36] European Central Bank. 2005. "Consolidation and Diversification in the Euro Area Banking Sector," Monthly Bulletin, May: 79-88.

[37] European Commission. 1988. "Creation of a European Financial Area," European Economy 36: 1-209.

[38] Ferrero, Andrea. 2007. "The Long-Run Determinants of U.S. External Imbalances," Federal Reserve Bank of New York Staff Report 295. 
[39] Floetotto, Max, and Nir Jaimovich. 2008. "Firm Dynamics, Markup Variations, and the Business Cycle," Journal of Monetary Economics 55(7): 1238-1252.

[40] Fogli, Alessandra, and Fabrizio Perri. 2006. "The 'Great Moderation' and the U.S. External Imbalance," NBER WP 12708.

[41] Gertler, Mark, and Peter Karadi. 2009. "A Model of Unconventional Monetary Policy," manuscript, New York University.

[42] Ghironi, Fabio, and Marc J. Melitz. 2005. "International Trade and Macroeconomic Dynamics with Heterogeneous Firms," Quarterly Journal of Economics 120(3): 865-915.

[43] Ghironi, Fabio, and Marc J. Melitz. 2007. "Trade Flow Dynamics with Heterogeneous Firms," American Economic Review Papers and Proceedings 97(2): 356-361.

[44] Giannone, Domenico, Michele Lenza, and Lucrezia Reichlin. 2008. "Explaining the Great Moderation: It Is Not the Shocks," Journal of the European Economic Association Papers and Proceedings 6(2-3): 621-633.

[45] González-Maestre, Miguel, and Luis M. Granero. 2003. "Industrial Loans and Market Structure," European Economic Review 47(5): 841-855.

[46] Gourinchas, Pierre-Olivier, and Helen Rey. 2007. "International Financial Adjustment," Journal of Political Economy 115(4): 665-703.

[47] Grossman, Gene M., and Elhanan Helpman .1991. Innovation and Growth in the Global Economy, MIT Press, Cambridge, MA.

[48] Gual, Jordi. 1999. "Deregulation, Integration, and Market Structure in European Banking," Journal of the Japanese and International Economies 13(4): 372-396.

[49] Gual, Jordi, and Damien J. Neven. 1993. "Deregulation of the European Banking Industry (1980-1991)," European Economy/Social Europe 3.

[50] Hayashi, Fumio. 1982. "Tobin's Marginal q and Average q: A Neoclassical Interpretation," Econometrica 50(1): 213-224.

[51] Hunt, Benjamin, and A. Rebucci. 2005. "The U.S. Dollar and the Trade Deficit: What Accounts for the Late 1990s?" International Finance 8(3): 399-434.

[52] Jayaratne, Jith, and Philip E. Strahan. 1996. "The Finance-Growth Nexus: Evidence from Bank Branch Deregulation," Quarterly Journal of Economics 61(3): 639-670.

[53] Jayaratne, Jith, and Philip E. Strahan. 1998. "Entry Restrictions, Industry Evolution and Dynamic Efficiency: Evidence from Commercial Banking," Journal of Law and Economics 41(1): 239-274.

[54] Justiniano, Alejandro, and Giorgio E. Primiceri. 2008. "The Time-Varying Volatility of Macroeconomic Fluctuations," American Economic Review 98(3): 604-641.

[55] Kerr, William, and Ramana Nanda. 2007. "Democratizing Entry: Banking Deregulations, Financing Constraints, and Entrepreneurship," Harvard Business School WP 07-033. 
[56] King, Robert G., Charles I. Plosser, and Sergio T. Rebelo. 1988. "Production, Growth, and Business Cycles: I. The Basic Neoclassical Model," Journal of Monetary Economics 21(2-3): 195-232.

[57] Kroszner, Randall S., and Philip E. Strahan. 1999. "What Drives Deregulation? Economics and Politics of the Relaxation of Bank Branching Restrictions," Quarterly Journal of Economics 64(4): 1437-1467.

[58] Lewis, Vivien. 2006. "Macroeconomic Fluctuations and Firm Entry: Theory and Evidence," manuscript, Catholic University Leuven.

[59] McLaughlin, Susan. 1995. "The Impact of Interstate Banking and Branching Reform: Evidence from the States," Current Issues in Economics and Finance 1(2), Federal Reserve Bank of New York.

[60] Méjean, Isabelle. 2008. "Can Firms' Location Decisions Counteract the Balassa-Samuelson Effect?" Journal of International Economics 76(2): 139-154.

[61] Mendoza, Enrique G., Vincenzo Quadrini, and Jose'-Victor Ríos-Rull. 2009. "Financial Integration, Financial Development, and Global Imbalances," Journal of Political Economy 117(3): $371-416$.

[62] Molyneux, Phil, and John O.S. Wilson. 2007. "Developments in European Banking," Journal of Banking \& Finance 31(7): 1907-1910.

[63] Morgan, Donald P., Bertrand Rime, and Philip E. Strahan. 2004. "Bank Integration and State Business Cycles," Quarterly Journal of Economics 129(4): 1555-1585.

[64] Obstfeld, Maurice, and Kenneth S. Rogoff. 2001. "The Six Major Puzzles in International Macroeconomics: Is There a Common Cause?" in NBER Macroeconomics Annual 2000 , ed. Ben S. Bernanke and Kenneth S. Rogoff, 339-390. Cambridge, MA: The MIT Press. .

[65] Petersen, Mitchell A., and Raghuram G. Rajan. 2002. "Does Distance Still Matter? The Information Revolution in Small Business Lending," Journal of Finance 57(6): 2533-2570.

[66] Rotemberg, Julio J., and Michael Woodford. 1992. "Oligopolistic Pricing and the Effects of Aggregate Demand on Economic Activity," Journal of Political Economy 100(6): 1153-1207.

[67] Stebunovs, Viktors. 2008. "Finance as a Barrier to Entry: U.S. Bank Deregulation and Business Cycle," manuscript, Board of Governors of the Federal Reserve System.

[68] Sims, Christopher A., and Tao Zha. 2006. "Were There Regime Switches in U.S. Monetary Policy?" American Economic Review 96(1): 54-81.

[69] Stiroh, K. J., and P. E. Strahan. 2003. "Competitive Dynamics of Deregulation: Evidence from U.S. Banking," Journal of Money, Credit and Banking 35: 801-828.

[70] Stock, James H., and Mark W. Watson. 2003. "Has the Business Cycle Changed and Why?" in Gertler, M., and K. S. Rogoff, eds., NBER Macroeconomics Annual 2002, MIT Press, Cambridge, MA, pp. 159-218.

[71] Tille, Cedric and Eric van Wincoop. 2010. "International Capital Flows," Journal of International Economics, 80(2): 157-175. 
[72] Uhlig, Herald. 1999. "A Toolkit for Analyzing Nonlinear Dynamic Stochastic Models Easily," in Marimon, R., and A. Scott, eds., Computational Methods for the Study of Dynamic Economies, Oxford: Oxford University Press, pp. 30-61.

[73] Vives, Xavier. 1991. "Banking Competition and European Integration," in Giovannini, A., and C. Mayer, eds., European Financial Integration, Cambridge University Press, Cambridge, UK.

[74] Woodford, Michael. 2003. Interest and Prices: Foundations of a Theory of Monetary Policy, Princeton University Press, Princeton, NJ.

[75] Yang, Xiaokai, and Ben J. Heijdra. 1993. "Monopolistic Competition and Optimum Product Diversity: Comment," American Economic Review 83(1): 295-301. 
Table 1. Benchmark Model, Summary

\begin{tabular}{|c|c|}
\hline Consumption price indexes & $\begin{aligned} 1 & =\left(\rho_{T, t}\right)^{\alpha}\left(\rho_{N, t}\right)^{1-\alpha} \\
1 & =\left(\rho_{T, t}^{*}\right)^{\alpha}\left(\rho_{N, t}^{*}\right)^{1-\alpha}\end{aligned}$ \\
\hline Tradable price indexes & $\begin{array}{l}1=N_{t}\left(\rho_{D, t}\right)^{1-\theta}+N_{t}^{*}\left(\rho_{X, t}^{*}\right)^{1-\theta} \\
1=N_{t}^{*}\left(\rho_{D, t}^{*}\right)^{1-\theta}+N_{t}\left(\rho_{X, t}\right)^{1-\theta}\end{array}$ \\
\hline Good prices, domestic market & $\begin{aligned} \rho_{D, t} & =\left(\rho_{T, t}\right)^{-1} \mu w_{t} / Z_{t} \\
\rho_{D, t}^{*} & =\left(\rho_{T, t}^{*}\right)^{-1} \mu w_{t}^{*} / Z_{t}^{*}\end{aligned}$ \\
\hline Good prices, export market & $\begin{array}{l}\rho_{X, t}=\left(\rho_{T, t}^{*}\right)^{-1} \tau Q_{t}^{-1} \mu w_{t} / Z_{t} \\
\rho_{X, t}^{*}=\left(\rho_{T, t}\right)^{-1} \tau^{*} Q_{t} \mu w_{t}^{*} / Z_{t}^{*}\end{array}$ \\
\hline Good prices, non-tradable & $\begin{aligned} \rho_{N, t} & =w_{t} / Z_{t} \\
\rho_{N, t}^{*} & =w_{t}^{*} / Z_{t}^{*}\end{aligned}$ \\
\hline Firm profits & $\begin{array}{l}d_{t}=\alpha\left(\rho_{D, t}\right)^{1-\theta} C_{t} / \theta+\alpha Q_{t}\left(\rho_{X, t}\right)^{1-\theta} C_{t}^{*} / \theta \\
d_{t}^{*}=\alpha\left(\rho_{D, t}^{*}\right)^{1-\theta} C_{t}^{*} / \theta+\alpha Q_{t}^{-1}\left(\rho_{X, t}^{*}\right)^{1-\theta} C_{t} / \theta\end{array}$ \\
\hline Bank profits & $\begin{array}{l}\pi_{t}=d_{t} N_{t}-\left(1+r_{t}\right) B_{t} \\
\pi_{t}^{*}=d_{t}^{*} N_{t}^{*}-\left(1+r_{t}^{*}\right) B_{t}^{*}\end{array}$ \\
\hline Firm entry & $\begin{aligned} q_{t} & =w_{t} /\left[(1-\delta) Z_{t}\right] \\
q_{t}^{*} & =w_{t}^{*} /\left[(1-\delta) Z_{t}^{*}\right]\end{aligned}$ \\
\hline Firm value & $\begin{array}{l}q_{t}=\beta E_{t}\left\{\left(C_{t+1} / C_{t}\right)^{-\gamma}\left[(1-1 / H) d_{t+1}+(1-\delta) q_{t+1}\right]\right\} \\
q_{t}^{*}=\beta E_{t}\left\{\left(C_{t+1}^{*} / C_{t}^{*}\right)^{-\gamma}\left[\left(1-1 / H^{*}\right) d_{t+1}^{*}+(1-\delta) q_{t+1}^{*}\right]\right\}\end{array}$ \\
\hline Number of firms & $\begin{array}{l}N_{t+1}=(1-\delta)\left(N_{t}+N_{E, t}\right) \\
N_{t+1}^{*}=(1-\delta)\left(N_{t}^{*}+N_{E, t}^{*}\right)\end{array}$ \\
\hline Euler equation, deposits & $\begin{array}{l}1=\beta\left(1+r_{t+1}\right) E_{t}\left[\left(C_{t+1} / C_{t}\right)^{-\gamma}\right] \\
1=\beta\left(1+r_{t+1}^{*}\right) E_{t}\left[\left(C_{t+1}^{*} / C_{t}^{*}\right)^{-\gamma}\right]\end{array}$ \\
\hline Euler equation, shares & $\begin{array}{l}v_{t}=\beta E_{t}\left[\left(C_{t+1} / C_{t}\right)^{-\gamma}\left(v_{t+1}+\pi_{t+1}\right)\right] \\
v_{t}^{*}=\beta E_{t}\left[\left(C_{t+1}^{*} / C_{t}^{*}\right)^{-\gamma}\left(v_{t+1}^{*}+\pi_{t+1}^{*}\right)\right]\end{array}$ \\
\hline Deposit market clearing & $\begin{aligned} B_{t+1} & =\left(w_{t} / Z_{t}\right) N_{E, t} \\
B_{t+1}^{*} & =\left(w_{t}^{*} / Z_{t}^{*}\right) N_{E, t}^{*}\end{aligned}$ \\
\hline Aggregate accounting & $\begin{array}{l}C_{t}+B_{t+1}=d_{t} N_{t}+w_{t} L \\
C_{t}^{*}+B_{t+1}^{*}=d_{t}^{*} N_{t}^{*}+w_{t}^{*} L^{*}\end{array}$ \\
\hline Balanced trade & $Q_{t} N_{t}\left(\rho_{X, t}\right)^{1-\theta} C_{t}^{*}=N_{t}^{*}\left(\rho_{X, t}^{*}\right)^{1-\theta} C_{t}$ \\
\hline
\end{tabular}


Table 2. Quantitative Model, Summary

\begin{tabular}{|c|c|}
\hline Consumption price index & $1=\left(\rho_{T, t}\right)^{\alpha}\left(\rho_{N, t}\right)^{1-\alpha}$ \\
\hline Tradable price index & $N_{t}\left(\rho_{D, t}\right)^{1-\theta}+N_{t}^{*}\left(\rho_{X, t}^{*}\right)^{1-\theta}=1$ \\
\hline Demand elasticity, home market & $\theta_{D, t}=\theta\left[1-\left(\rho_{D, t}\right)^{1-\theta}\right]$ \\
\hline Good prices, home market & $\rho_{D, t}=\left(\rho_{T, t}\right)^{-1}\left(\frac{\theta_{D, t}}{\theta_{D, t}-1}\right) \frac{w_{t}}{Z_{t}}$ \\
\hline Demand elasticity, export market & $\theta_{X, t}=\theta\left[1-\left(\rho_{X, t}\right)^{1-\theta}\right]$ \\
\hline Good prices, export market & $\rho_{X, t}=\left(\rho_{T, t}^{*}\right)^{-1} \tau Q_{t}^{-1}\left(\frac{\theta_{X, t}}{\theta_{X, t}-1}\right) \frac{w_{t}}{Z_{t}}$ \\
\hline Good prices, non-tradable & $\rho_{N, t}=\frac{w_{t}}{Z_{t}}$ \\
\hline Firm profits, home market & $d_{D, t}=\frac{\alpha}{\theta_{D, t}}\left(\rho_{D, t}\right)^{1-\theta} C_{t}$ \\
\hline Firm profits, export market & $d_{X, t}=\frac{\alpha}{\theta_{X, t}} Q_{t}\left(\rho_{X, t}\right)^{1-\theta} C_{t}^{*}$ \\
\hline Bank profits & $\pi_{t}=\left(d_{D, t}+d_{X, t}\right) N_{t}-\left(1+r_{t}\right)\left(B_{t}+B_{t}^{*}\right)$ \\
\hline Firm entry & $q_{t}=w_{t} /\left[(1-\delta) Z_{t}\right]$ \\
\hline Firm value & $q_{t}=\beta E_{t}\left\{\left(\frac{C_{t+1}}{C_{t}}\right)^{-1}\left[\begin{array}{c}\left(1-\frac{1}{H} \frac{\theta}{\theta_{D, t+1}}\right) d_{D, t+1} \\
+\left(1-\frac{1}{H} \frac{\theta}{\theta_{X, t+1}}\right) d_{X, t+1}+(1-\delta) q_{t+1}\end{array}\right.\right.$ \\
\hline Number of firms & $N_{t}=(1-\delta)\left(N_{t-1}+N_{E, t-1}\right)$ \\
\hline Euler equation, domestic deposits & $1=\beta\left(1+r_{t+1}\right) E_{t}\left[\left(C_{t+1} / C_{t}\right)^{-1}\right]$ \\
\hline Euler equation, deposits abroad & $1+\eta B_{*, t}=\beta\left(1+r_{t+1}^{*}\right) E_{t}\left[\left(Q_{t+1} / Q_{t}\right)\left(C_{t+1} / C_{t}\right)^{-\gamma}\right]$ \\
\hline Euler equation (shares) & $v_{t}=\beta E_{t}\left[\left(C_{t+1} / C_{t}\right)^{-\gamma}\left(v_{t+1}+\pi_{t+1}\right)\right]$ \\
\hline Deposit market clearing & $B_{t+1}+B_{t+1}^{*}=\left(W_{t} / Z_{t}\right) N_{E, t}$ \\
\hline Labor supply & $\chi\left(L_{t}\right)^{1 / \varphi}=w_{t}\left(C_{t}\right)^{-\gamma}$ \\
\hline Labor market clearing & $L_{t}=\left(\frac{\theta_{D, t}-1}{w_{t}} d_{D, t}+\frac{\theta_{X, t}-1}{w_{t}} d_{X, t}\right) N_{t}+\frac{N_{E, t}}{Z_{t}}+\frac{1-\alpha}{Z_{t}} \frac{C_{t}}{\rho_{N, t}}$ \\
\hline \multirow[t]{3}{*}{ Net foreign assets } & $Q_{t} B_{*, t+1}-B_{t+1}^{*}=Q_{t}\left(1+r_{t}^{*}\right) B_{*, t}-\left(1+r_{t}\right) B_{t}^{*}$ \\
\hline & $+\frac{1}{2}\left(w_{t}-Q_{t} w_{t}^{*}\right)+\frac{1}{2}\left(d_{t} N_{t}-Q_{t} d_{t}^{*} N_{t}^{*}\right)$ \\
\hline & $-\frac{1}{2}\left(C_{t}-Q_{t} C_{t}^{*}\right)-\frac{1}{2}\left(\frac{w_{t}}{Z_{t}} N_{E, t}-Q_{t} \frac{w_{t}^{*}}{Z_{t}^{*}} N_{E, t}^{*}\right)$ \\
\hline
\end{tabular}


Table 3. Standard Deviations Before and After Deregulation

\begin{tabular}{|c|c|c|c|c|c|c|c|}
\hline \multicolumn{8}{|c|}{ Backus-Keohe-Kydland Calibration } \\
\hline \multicolumn{4}{|c|}{ Model with Non-Traded Goods } & \multicolumn{4}{|c|}{ Model with Home Bias } \\
\hline & Before & After & $\%$ Change & & Before & After & $\%$ Change \\
\hline$Y_{R}$ & 5.5931 & 5.0979 & -8.85 & $Y_{R}$ & 3.9046 & 3.5368 & -9.42 \\
\hline$Y_{R}^{*}$ & 5.5931 & 5.2681 & -5.81 & $Y_{R}^{*}$ & 3.9046 & 3.8220 & -2.11 \\
\hline$C_{R}$ & 1.2073 & 1.0522 & -12.84 & $C_{R}$ & 1.6877 & 1.3929 & -17.47 \\
\hline$C_{R}^{*}$ & 1.2073 & 1.2363 & 2.40 & $C_{R}^{*}$ & 1.6877 & 1.6723 & -0.92 \\
\hline$I_{R}$ & 129.4197 & 105.2090 & -18.71 & $I_{R}$ & 44.6518 & 36.0585 & -19.25 \\
\hline$I_{R}^{*}$ & 129.4196 & 119.4414 & -7.71 & $I_{R}^{*}$ & 44.6518 & 43.2114 & -3.23 \\
\hline$L$ & 6.1059 & 5.4569 & -10.63 & $L$ & 4.8151 & 4.2190 & -12.38 \\
\hline$L^{*}$ & 6.1059 & 5.6132 & -8.07 & $L^{*}$ & 4.8151 & 4.6534 & -3.36 \\
\hline$\tilde{Q}$ & 1.0491 & 0.9122 & -13.05 & $\tilde{Q}$ & 1.2296 & 1.0539 & -14.29 \\
\hline \multicolumn{8}{|c|}{ Baxter Calibration } \\
\hline \multicolumn{4}{|c|}{ Model with Non-Traded Goods } & \multicolumn{4}{|c|}{ Model with Home Bias } \\
\hline & Before & After & $\%$ Change & & Before & After & $\%$ Change \\
\hline$Y_{R}$ & 1.8832 & 1.6850 & -10.53 & $Y_{R}$ & 2.1956 & 1.9499 & -11.19 \\
\hline$Y_{R}^{*}$ & 1.8832 & 1.8586 & -1.31 & $Y_{R}^{*}$ & 2.1956 & 2.2002 & 0.21 \\
\hline$C_{R}$ & 1.1724 & 1.1085 & -5.46 & $C_{R}$ & 1.3008 & 1.1847 & -8.93 \\
\hline$C_{R}^{*}$ & 1.1724 & 1.1892 & 1.43 & $C_{R}^{*}$ & 1.3008 & 1.3160 & 1.17 \\
\hline$I_{R}$ & 23.4854 & 16.9301 & -27.91 & $I_{R}$ & 15.9495 & 12.1660 & -23.72 \\
\hline$I_{R}^{*}$ & 23.4854 & 21.5360 & -8.30 & $I_{R}^{*}$ & 15.9495 & 15.7272 & -1.39 \\
\hline$L$ & 0.9873 & 0.8018 & -18.79 & $L$ & 1.4544 & 1.2487 & -14.14 \\
\hline$L^{*}$ & 0.9873 & 0.8485 & -14.06 & $L^{*}$ & 1.4544 & 1.3687 & -5.89 \\
\hline$\tilde{Q}$ & 0.1105 & 0.1278 & 15.67 & $\tilde{Q}$ & 0.4420 & 0.3825 & -13.46 \\
\hline
\end{tabular}



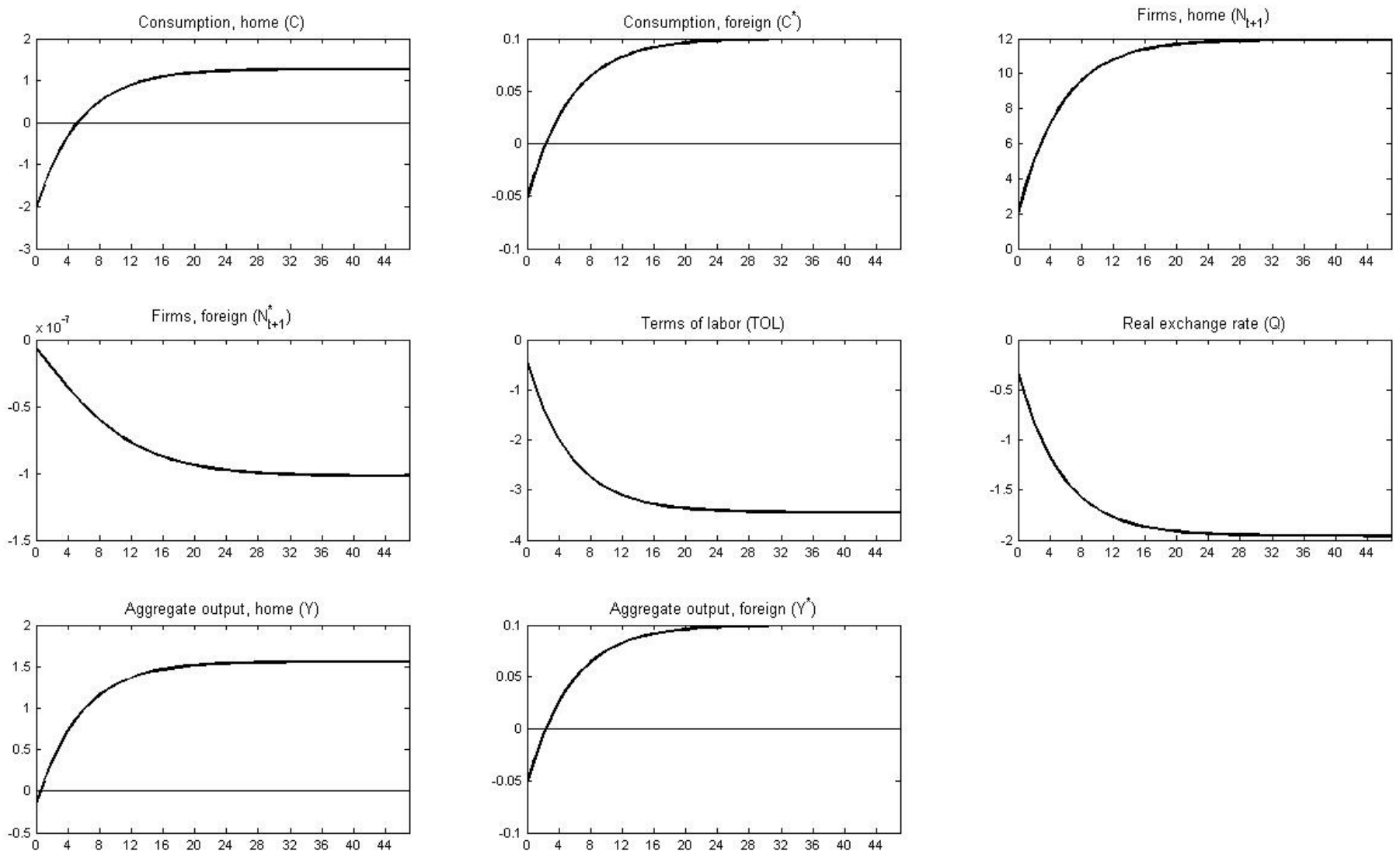

Figure 1. Banking Deregulation under Financial Autarky 

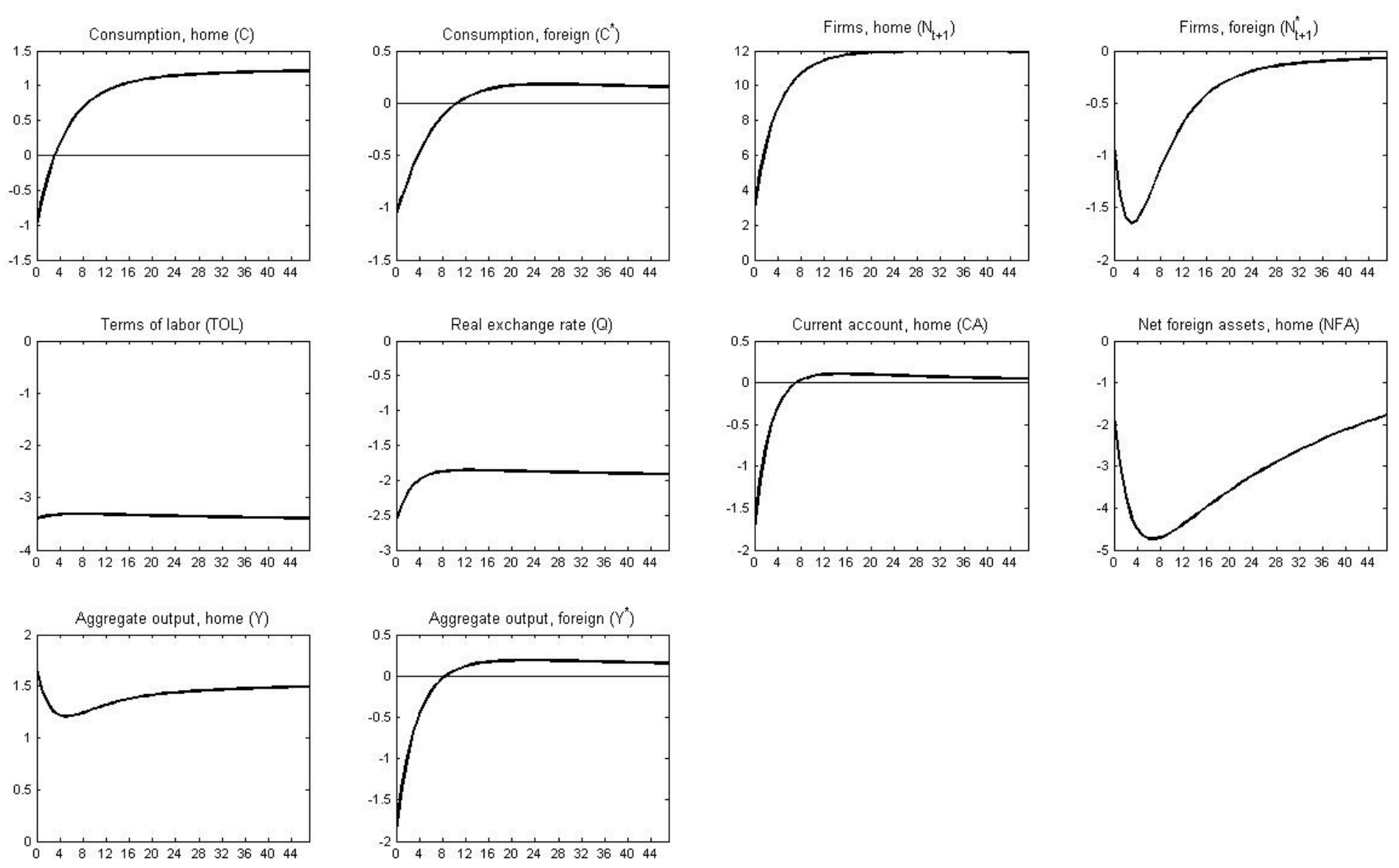

Figure 2. Banking Deregulation with International Deposits 

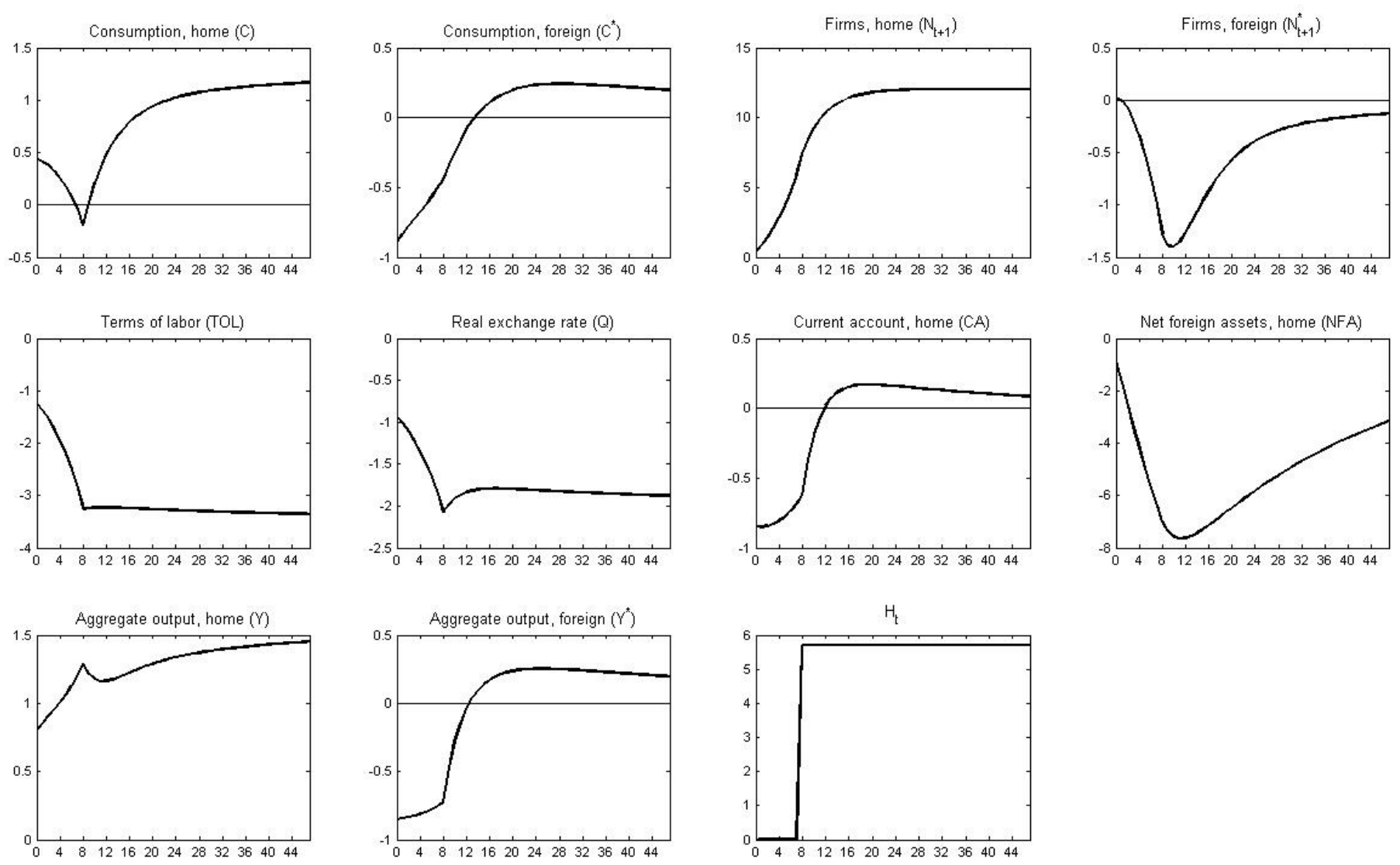

Figure 3. Anticipated Banking Deregulation with International Deposits 

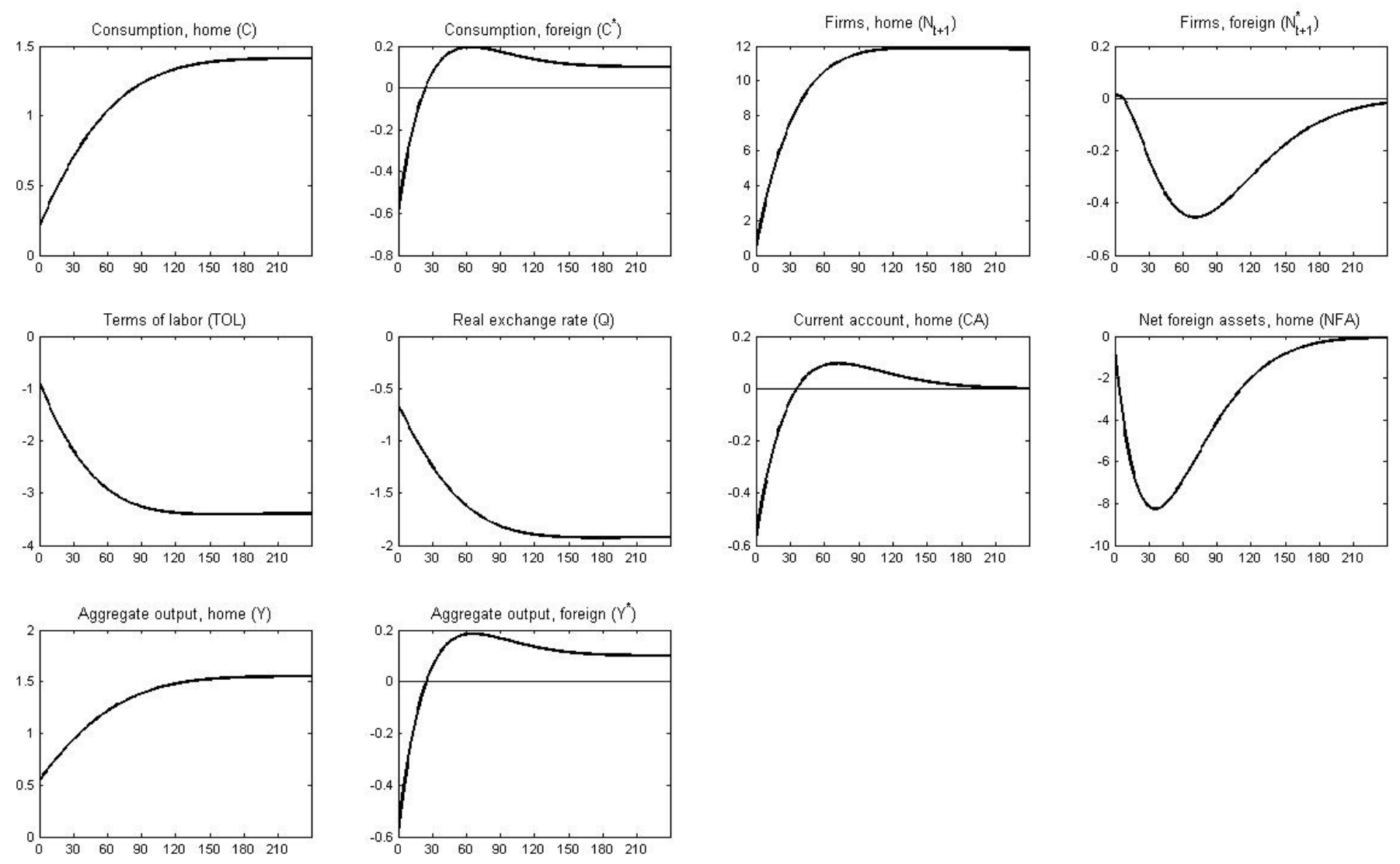

Figure 4. Banking Deregulation with International Deposits, Grossman-Helpman Entry Cost 

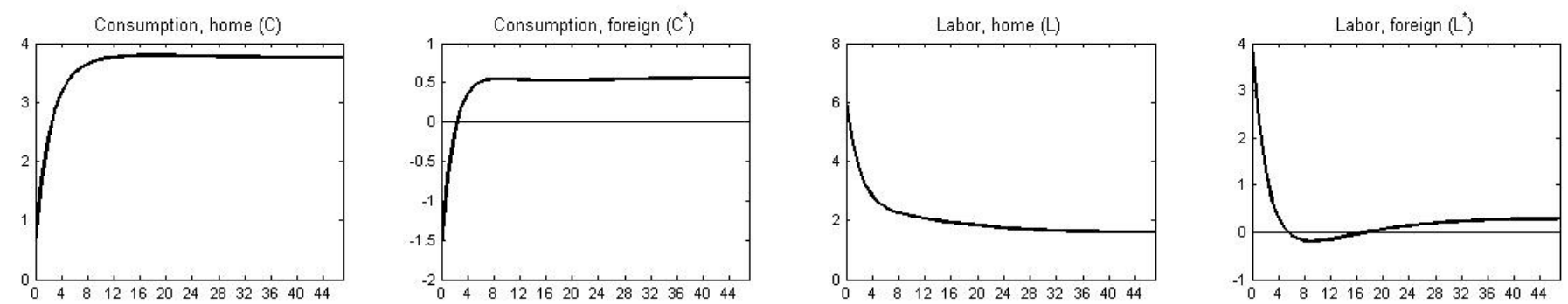

Firms, home $\left(\mathbb{N}_{\mathrm{t}+1}\right)$
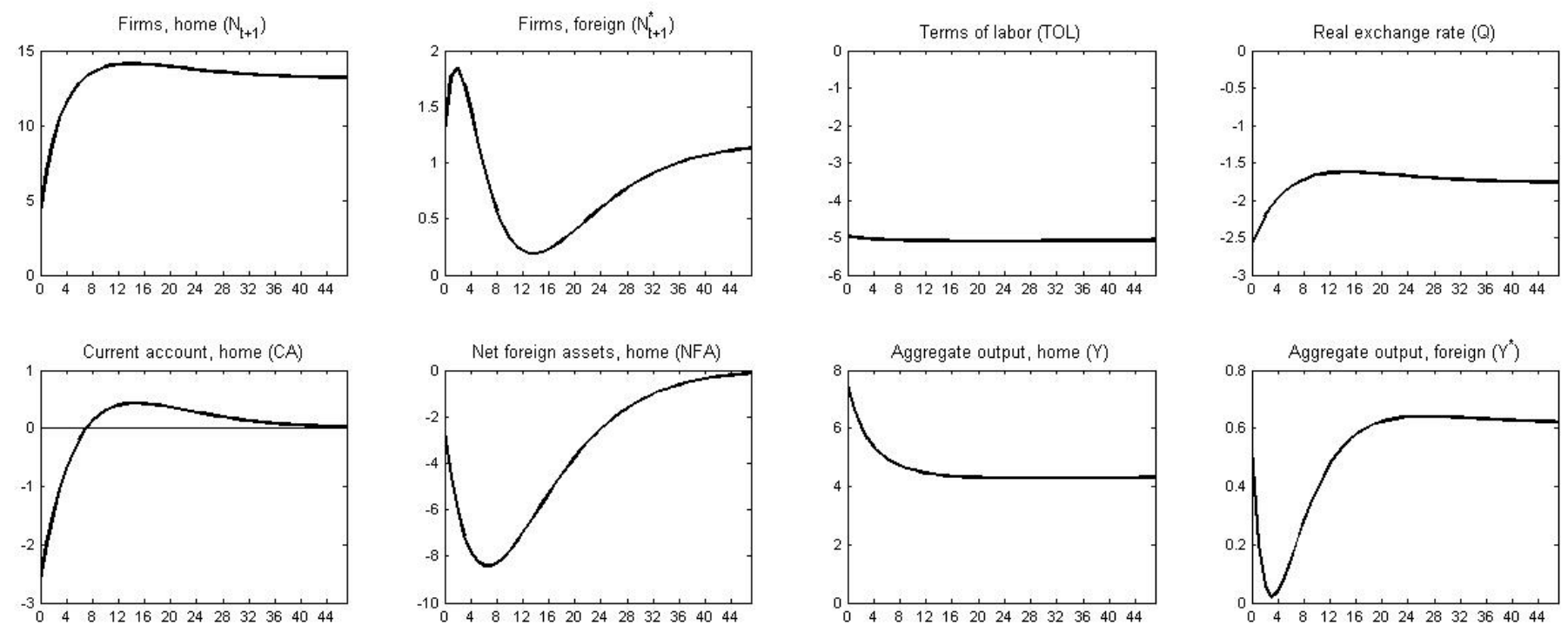

Figure 5. Banking Deregulation with Elastic Labor and Endogenous Firm Markups 

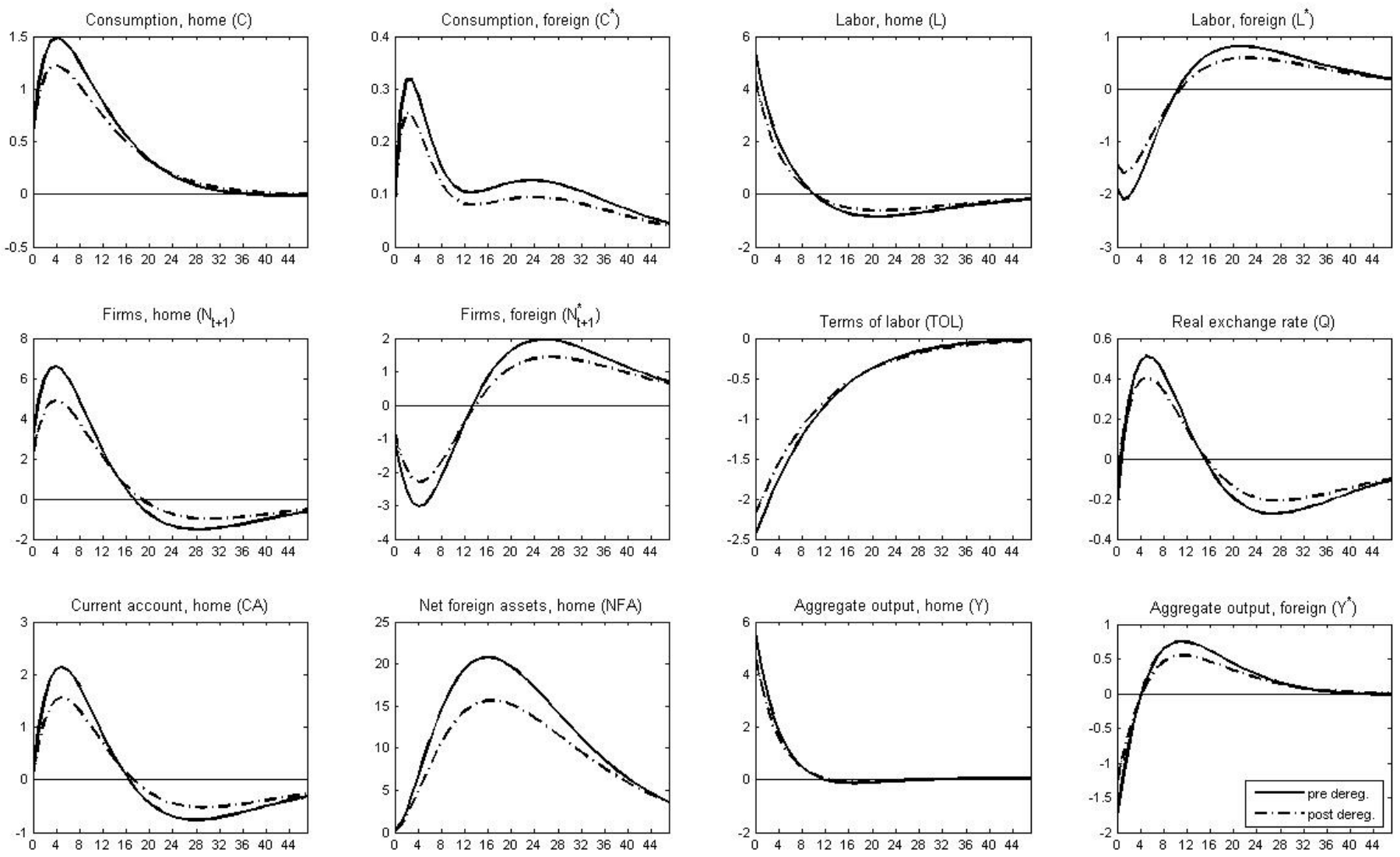

Figure 6. Business Cycles, Pre- and Post-Deregulation 

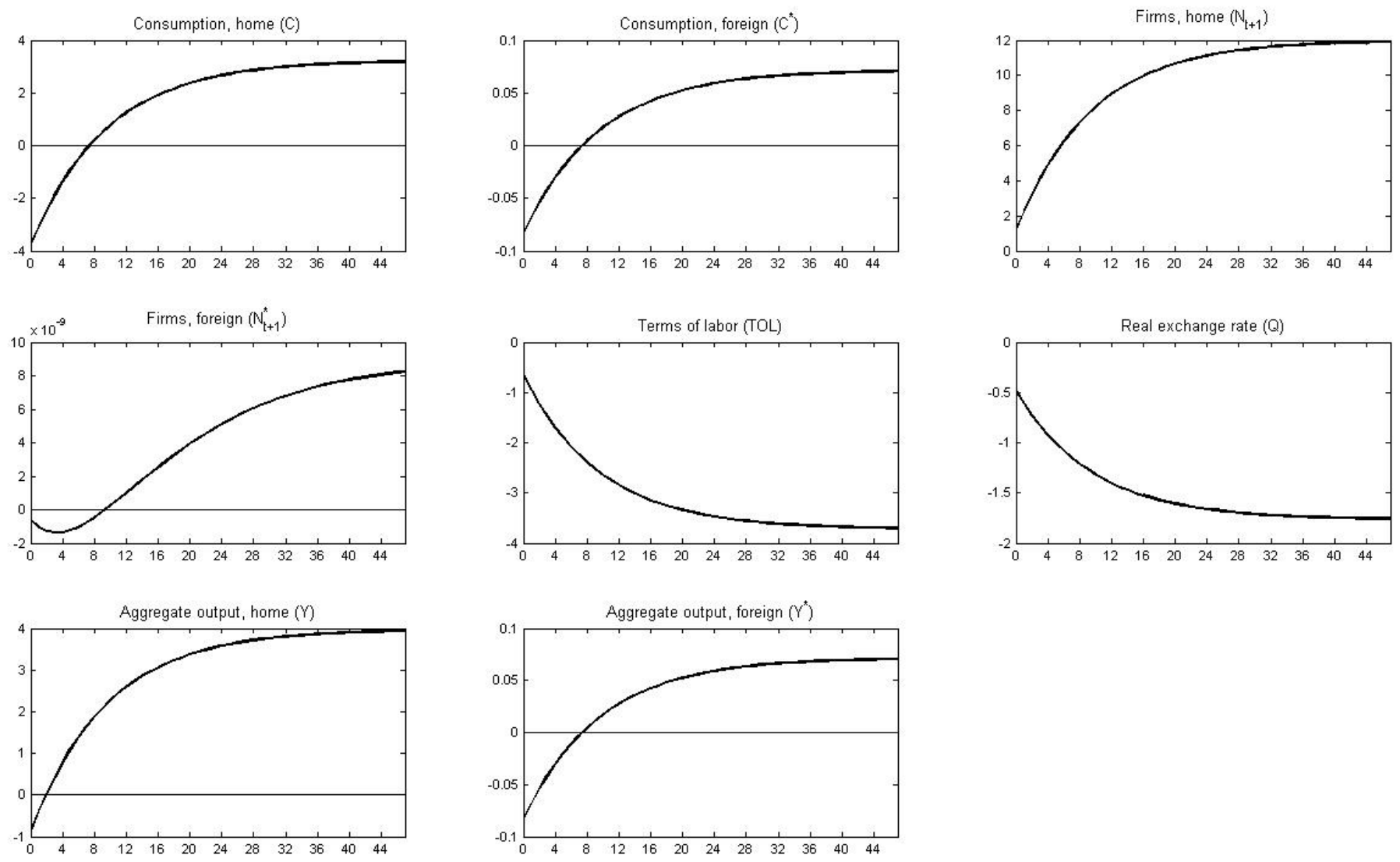

Figure A.1. Banking Deregulation under Financial Autarky, Home Bias Model 

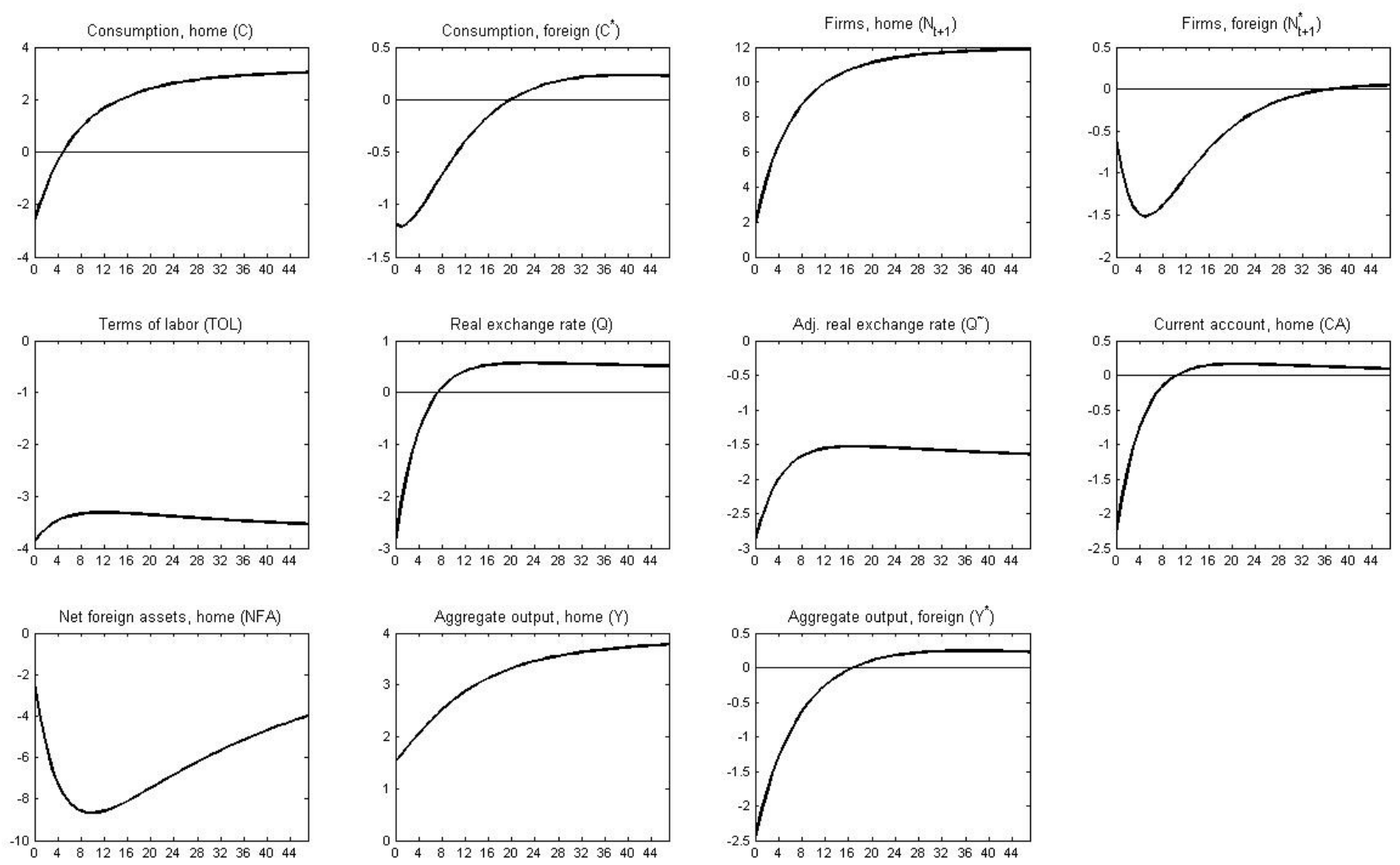

Figure A.2. Banking Deregulation with International Deposits, Home Bias Model 

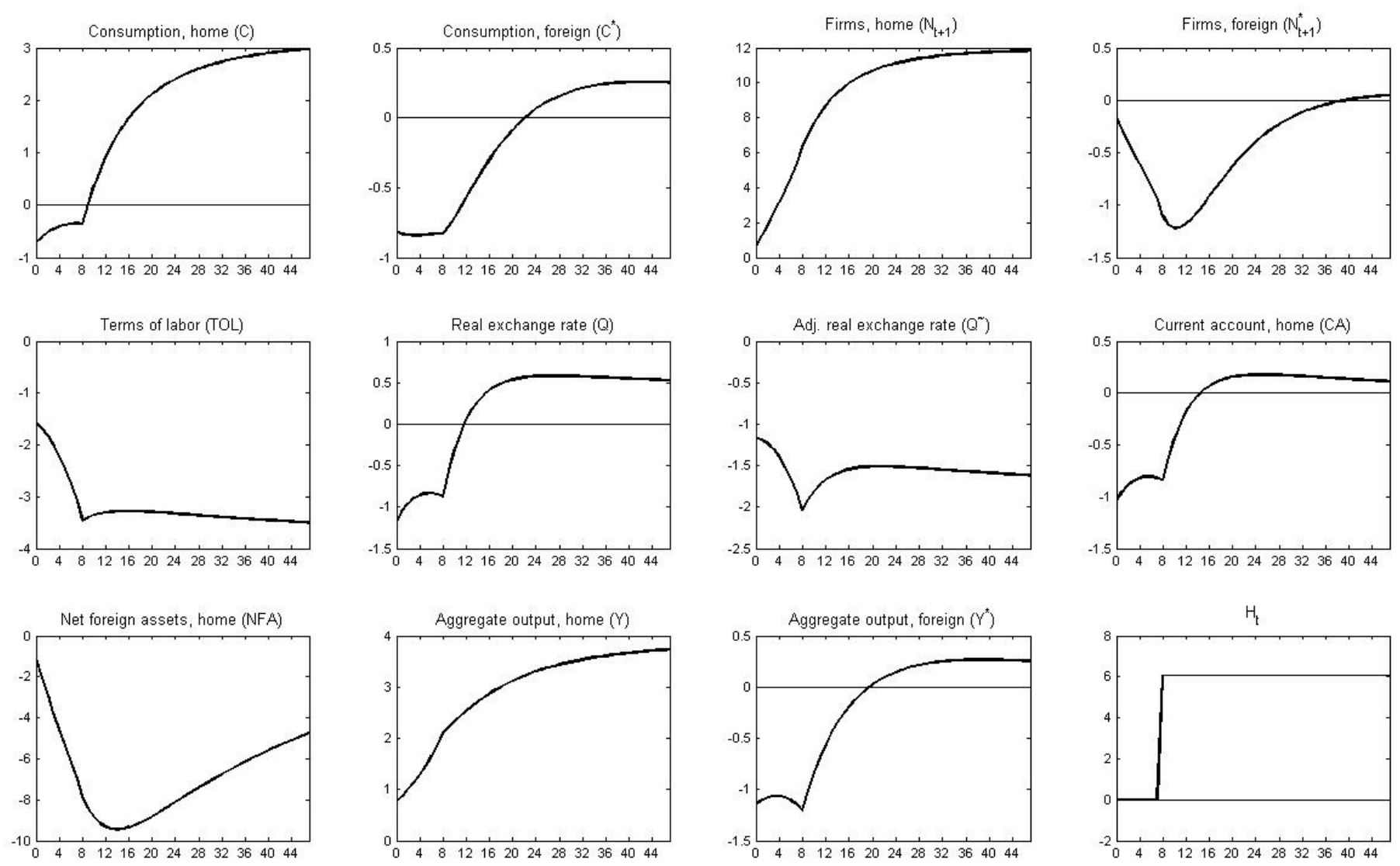

Figure A.3. Anticipated Banking Deregulation with International Deposits, Home Bias Model 
Consumption, home (C)

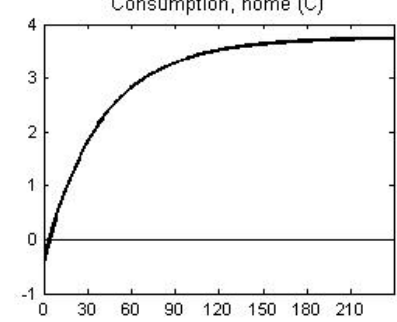

Terms of labor (TOL)
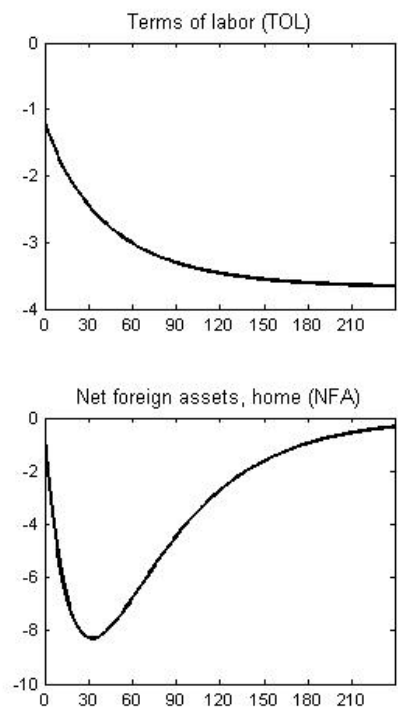

Consumption, foreign (C)

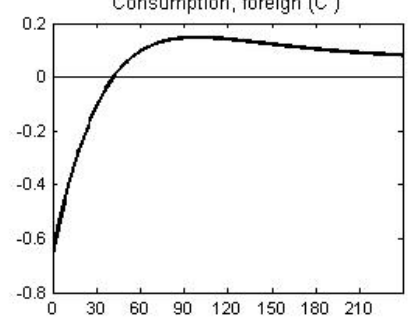

Real exchange rate $(Q)$
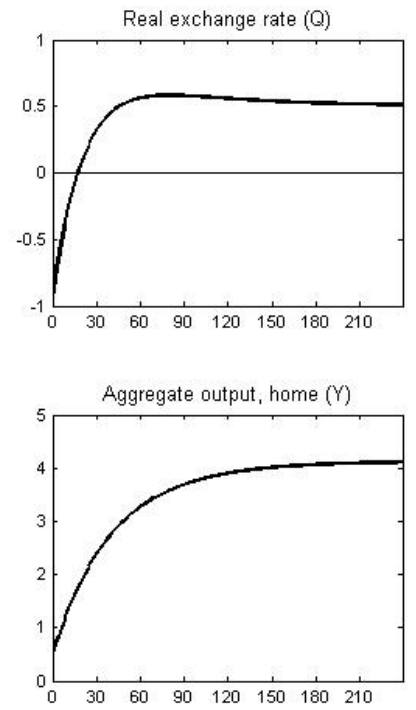

Firms, home $\left(\mathbb{N}_{t+1}\right)$

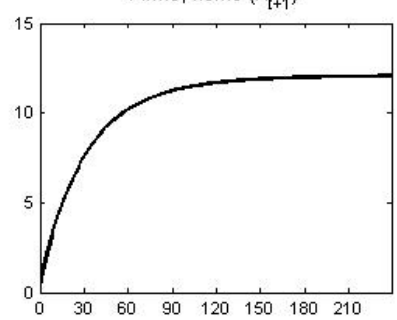

Adj. real exchange rate $\left(Q^{*}\right)$
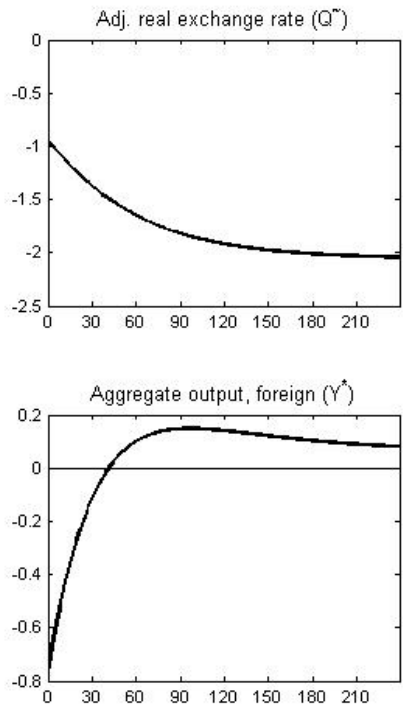

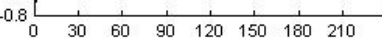
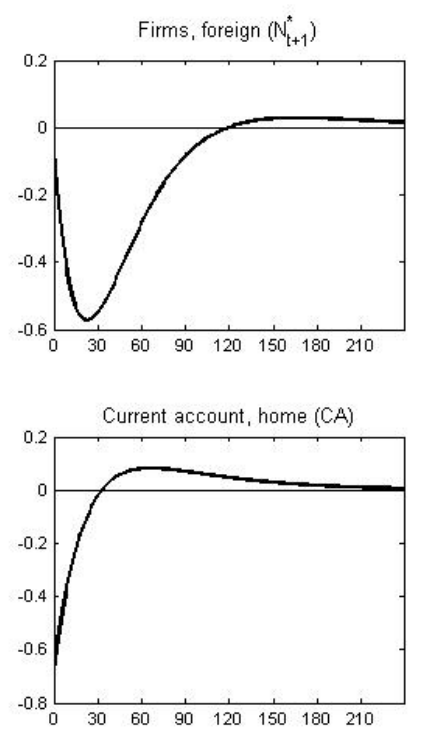

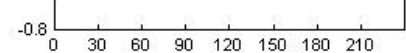

Figure A.4. Banking Deregulation with International Deposits, Grossman-Helpman Entry Cost, Home Bias Model 

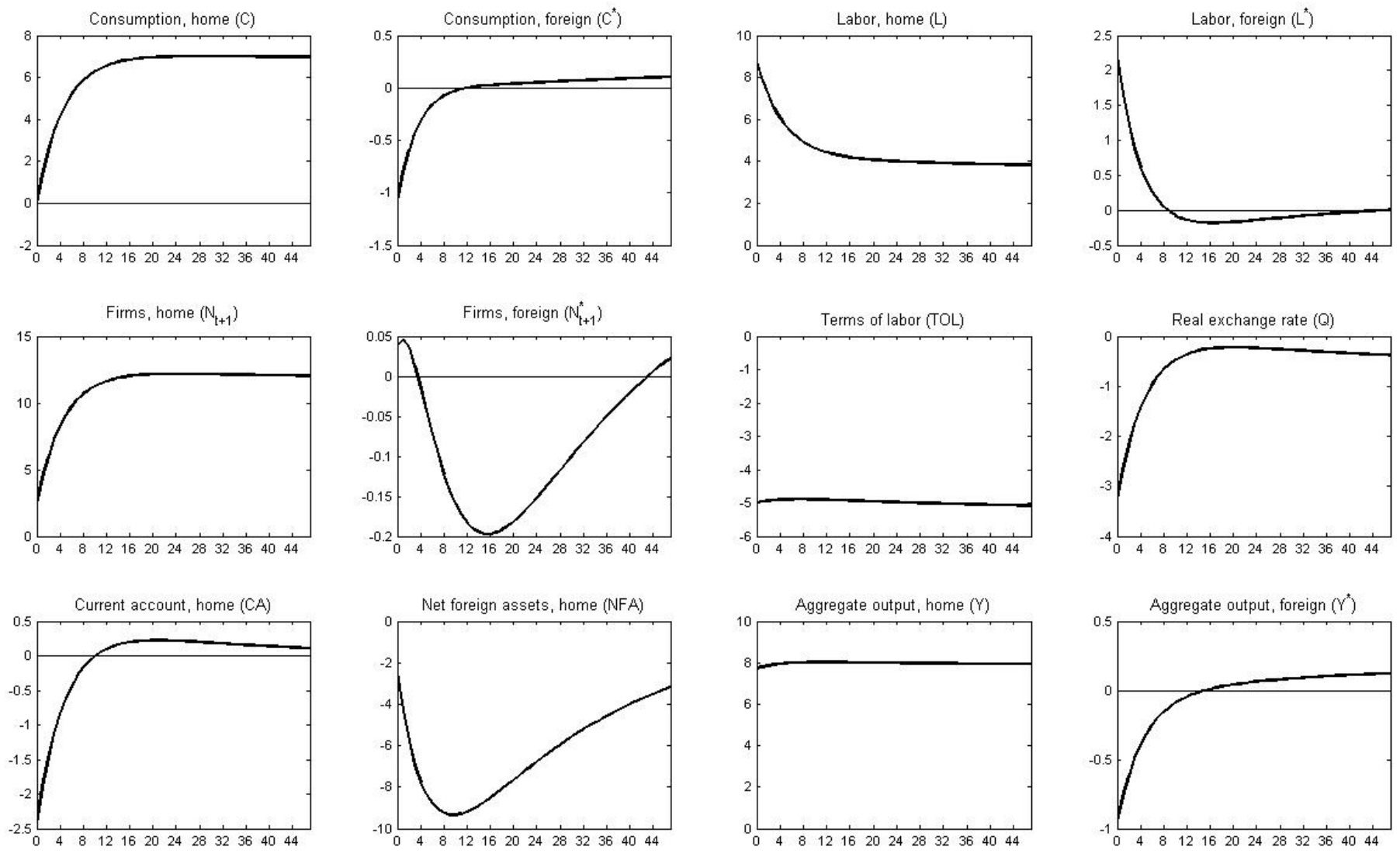

Figure A.5. Banking Deregulation with Elastic Labor and Endogenous Firm Markups, Home Bias Model 

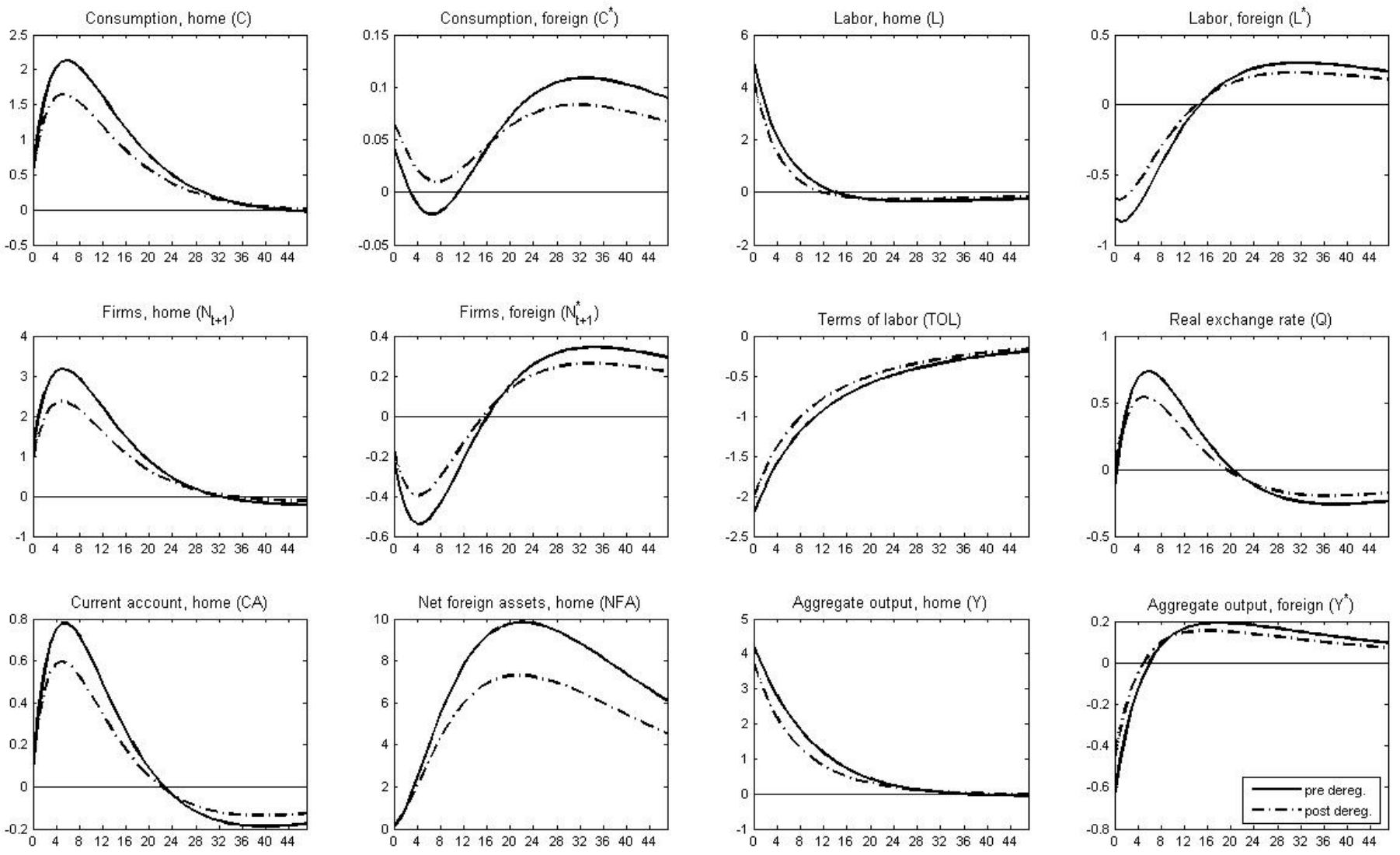

Figure A.6. Business Cycles, Pre- and Post-Deregulation, Home Bias Model 